Historic, archived document

Do not assume content reflects current scientific knowledge, policies, or practices. 

iited States

epartment of

Agriculture

Forest

Service

North Central

Research

Station

Resource Bulletin NC - 193

iss
Indiana's Timber

Industry - An Assessment of Timber Product Output and Use, 1995

Ronald L. Hackett and Jeff Settle

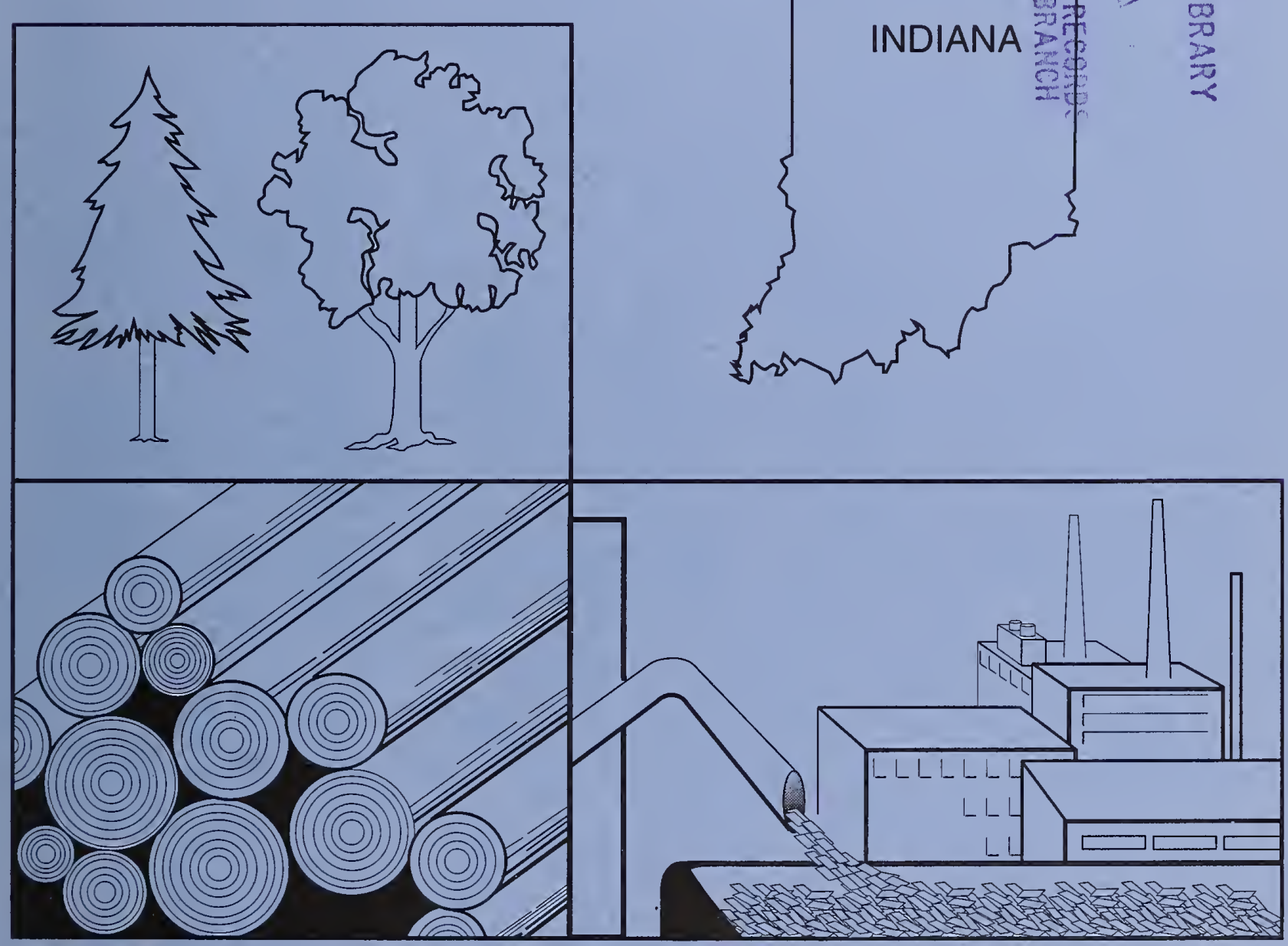


North Central Research Station

Forest Service-U.S. Department of Agriculture

1992 Folwell Avenue

St. Paul, Minnesota 55108

Manuscript approved for publication May 24, 1998

1998 


\section{FOREWORD}

In this bulletin, we discuss recent Indiana forest industry trends and report the results of a detailed study of forest industry, industrial roundwood production, and associated primary mill wood and bark residue in Indiana in 1995. Such detailed information is necessary for intelligent planning and decisionmaking in wood procurement, forest resource management, and forest industry development. Likewise, researchers need current forest industry and industrial roundwood information for planning projects.

Special thanks are given to the primary wood-using firms that supplied information for this study and to the Indiana Department of Natural Resources for canvassing the respondents. Their cooperation is greatly appreciated.

All board foot data in this report have been converted to International 1/4-inch scale by applying a multiplier of 1.08 to all saw log volume reported in Scribner Decimal C scale by sawmills, a multiplier of 1.04 to all veneer log volume reported in Scribner Decimal C scale by veneer mills, a multiplier of 1.38 to all saw log volume reported in Doyle scale by sawmills, and a multiplier of 1.14 to all veneer log volume reported in Doyle scale by veneer mills.

The last published report from a detailed study of all industrial roundwood output in Indiana was in 1990. Most comparisons in this report are with the 1990 study results. Row and column data of tables may not sum due to rounding, but data in each table cell are accurately displayed. 


\section{CONTENTS}

Highlights ........................................................................... 1

Primary Timber Industry—Industrial Roundwood ............................ 1

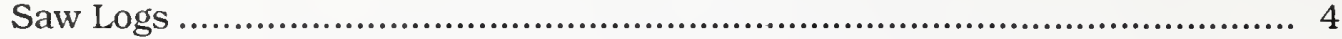

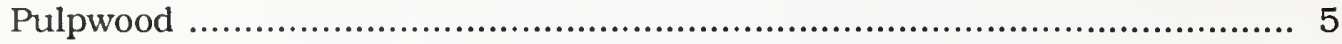

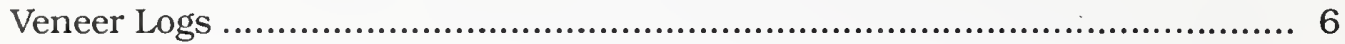

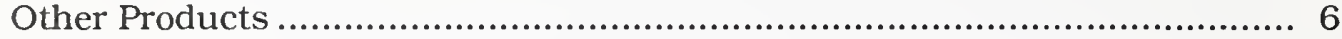

Timber Removals ........................................................................ 7

Harvest Residues ................................................................. 8

Primary Mill Residue ................................................................. 8

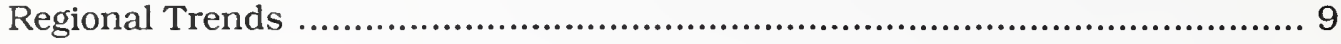

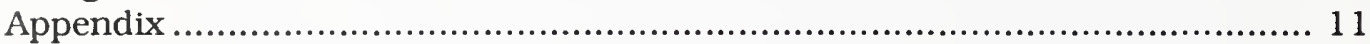

Study Methods ..................................................................... 11

Definition of Terms ................................................................ 12

Common and Scientific Names of Tree Species Mentioned in the Report .... 14

Table Titles ............................................................................... 15

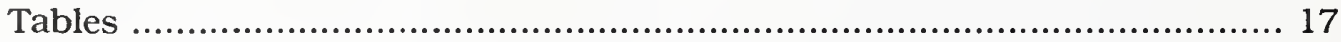




\title{
Indiana's Timber Industry-An Assessment of Timber Product Output and Use, 1995
}

\author{
Ronald L. Hackett and Jeff Settle
}

\section{HIGHLIGHTS}

\section{PRIMARY TIMBER INDUSTRY-INDUSTRIAL ROUNDWOOD}

- In 1995, Indiana's primary wood-using industry was comprised of 209 mills, including 3 pulpmills, 12 veneer mills, and 2 miscellaneous mills (table 1).

- Most of the State's primary wood-using mills are located in the Lower Wabash and Knobs Forest Survey Units (figs. 1, 2).

- Between 1990 and 1995, Indiana's primary wood-using industry decreased by 61 mills, most of which were sawmills.

- In 1995, Indiana's primary wood-using industry processed 75.9 million cubic feet of roundwood, a decline of 5 percent or 4.2 million cubic feet from 1990 (table 2).

- Indiana's 192 sawmills processed more than 67 million cubic feet of roundwood in 1995, a decrease of more than 7 percent from 1990. Pulpwood decreased from 3 million cubic feet in 1990 to 1.3 million cubic feet in 1995. However, veneer log and bolts processed increased by more than 160 percent from 1990 to 1995.

Ronald L. Hackett, Research Forester, received a B.S. in forest resources from the University of Minnesota. He joined the Forest Service in December 1974, and has been working with the North Central Station's Forest Inventory and Analysis Unit since.

Jeff Settle, Utilization and Marketing Supervisor, received a B.S. from Indiana State University in 1984. He has worked for the Indiana Division of Forestry since 1987. He joined the Utilization and Marketing section in 1996.
- Hardwoods made up 98 percent of the roundwood processed by the State's primary wood-using industry in 1995.

- In 1995, more than 66 million cubic feet of industrial roundwood was harvested from Indiana's forest, a decrease of more than 17 percent from 1990 (table 3). Hardwoods decreased by an average of 19 percent during the same period; softwoods increased from 117 thousand cubic feet to 1,315 thousand cubic feet or more than 11 times the volume of 1990 softwoods harvested.

- The decrease in hardwood production was associated with the decreased use of red oak and yellow-poplar for saw logs. This was actually offset by the increased use of red oak and yellow-poplar for veneer logs and pulpwood.

- The elevenfold increase in softwood produc tion was associated with the increased use of shortleaf and other pines for saw logs and pulpwood.

- Saw logs remained the predominant roundwood product harvested from Indiana's forests (fig. 3).

- The State's industrial roundwood production was concentrated in the Knobs Unit, which provided more than 40 percent of the State's 1995 production. The Lower Wabash and Northern Units provided another 26 and 25 percent of the industrial roundwood, respectively (fig. 4).

- The Knobs Unit provided more than onethird of the saw logs, nearly two-thirds of the veneer logs, and two-thirds of the pulpwood in 1995. The Lower Wabash and Northern Units combined provided more than half of the saw logs, nearly one-third of the veneer logs, and one-third of the pulpwood production in the State. 
INDIANA

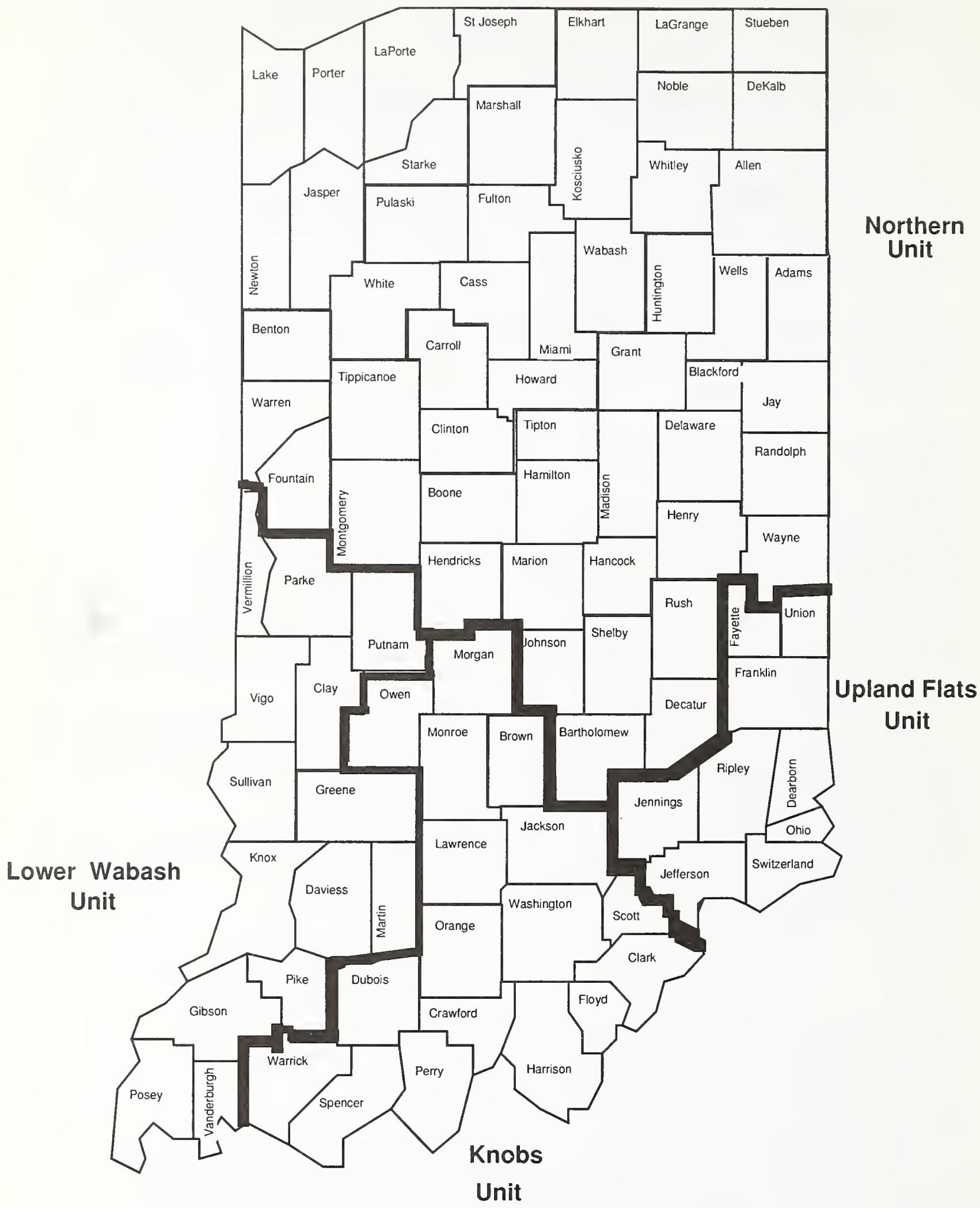

Figure 1.-Forest Survey Units in Indiana. 


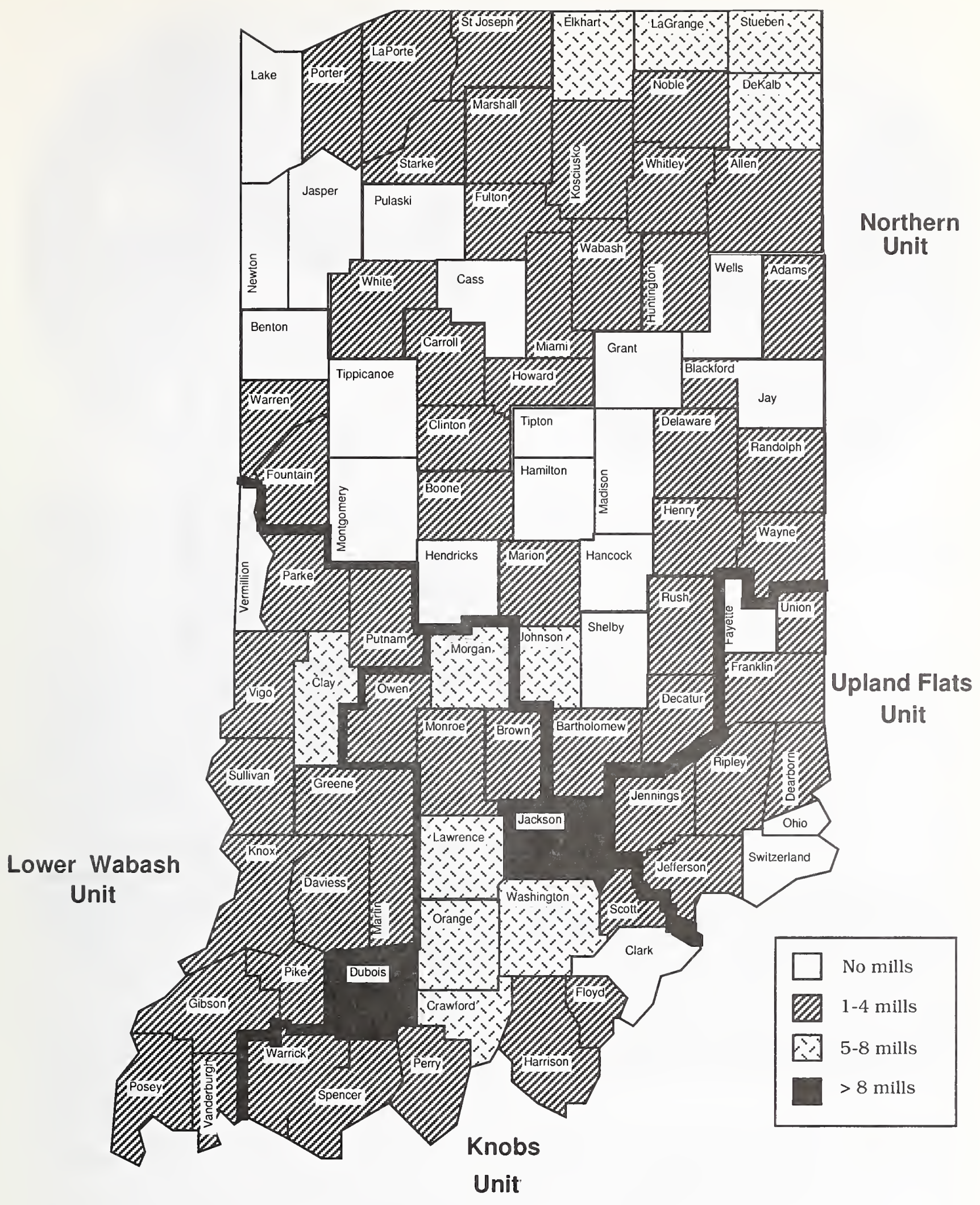

Figure 2.-Number of primary wood-using mills by county, Indiana, 1995. 


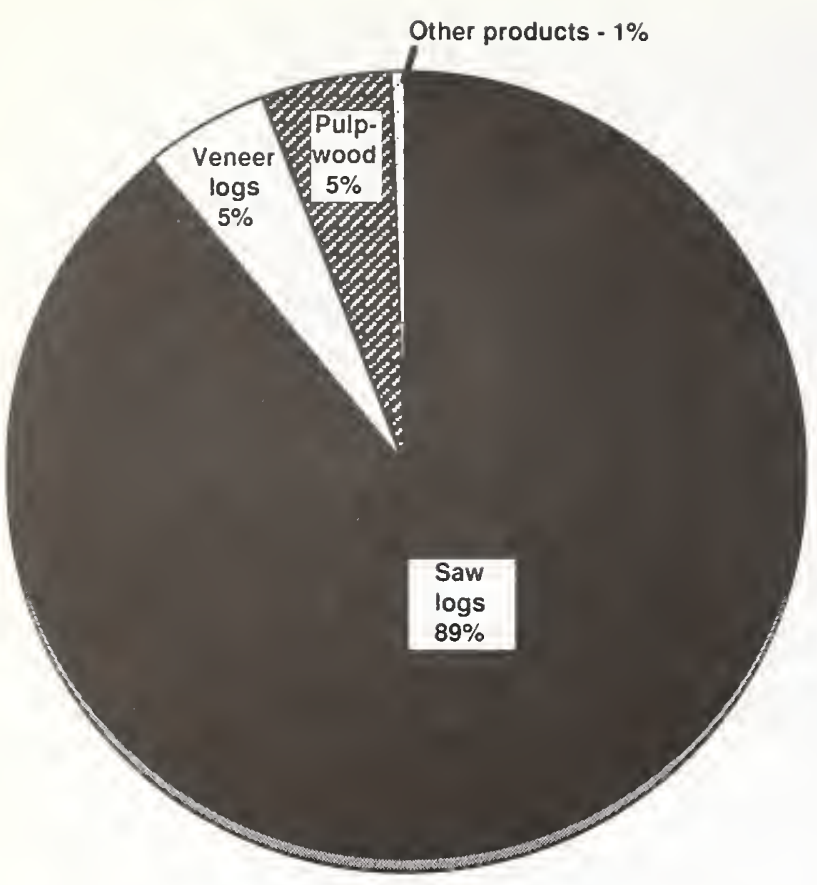

Figure 3.-Distribution of industrial roundwood production by product, Indiana, 1995.

\section{SAW LOGS}

- Loggers harvested more than 353 million board feet of saw logs from Indiana's forest in 1995, down nearly 19 percent (82 million board feet) from 1990 (table 4).

- Most of the decline was associated with red oak, yellow-poplar, white oak, and sycamore.

- Saw-log receipts also decreased by more than 20 percent; most of the decline was associated with red oak, yellow-poplar, white oak, and sycamore.

- Major saw-log producing counties with more than 10 million board feet each were Dubois, Owen, Washington, Clay, Greene, and Vigo (table 5).

- Indiana sawmills processed more than 96 percent of the State's production of saw logs (table 6) (fig. 5). The remainder was exported to Michigan, Kentucky, Ohio, and other States outside the region.

- Ohio and other States were the two largest recipients of Indiana saw logs. Red and white oak and black walnut were the largest species exported to Ohio. Other States

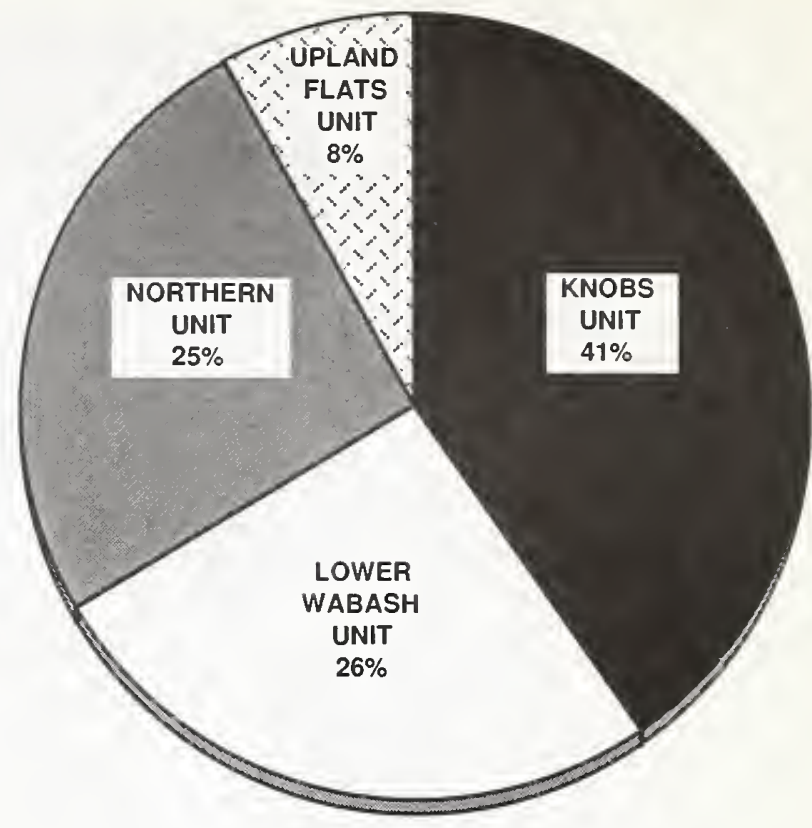

Figure 4.-Distribution of industrial roundwood production by Forest Survey Unit, Indiana, 1995.

received 4.7 million board feet of mostly shortleaf pine and other pines from Indiana in 1995. Indiana loggers sent nearly 1.5 million board feet, mostly red and white oak and soft maple, to Michigan in 1995. Kentucky received 2.9 million board feet, mostly red and white oak, yellow-poplar, and tupelo.

- In 1995, the Knobs and Lower Wabash Units provided 2.8 million board feet of saw logs to Kentucky, the Northern and Upland Flats Units provided nearly 5 million board feet to Ohio, and the Knobs and Upland Flats Units provided nearly 4.7 million board feet to other States outside the region.

- Indiana supplied more than 85 percent of the saw-log volume needed by its sawmills in 1995 (table 7). The remainder was imported from Illinois, Kentucky, Michigan, Ohio, and other States outside the region.

- In 1995, of the 192 sawmills in Indiana, four mills produced handle blank $\mathrm{s}$. These mills used more than 116 thousand board feet of hardwoods-mainly ash (93 mbf), hickory (13 mbf), and hard maple (10 mbf)-in producing handle blanks. Handle blank mills in Indiana received more than 6 


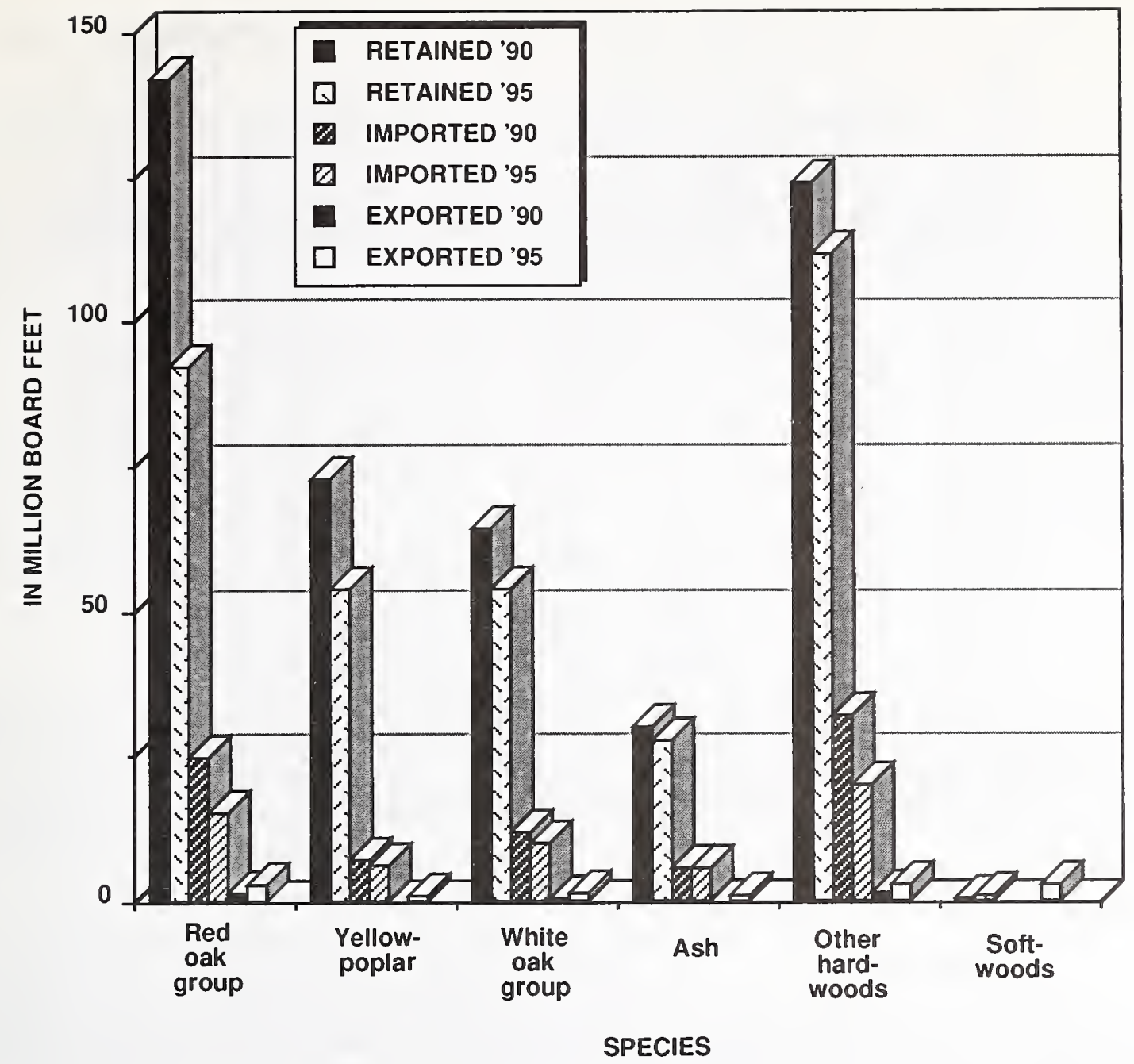

Figure 5.-Saw-log production exported (mills outside Indiana), imported, and retained by select species in Indiana, 1990 and 1995.

thousand board feet of hardwood from Kentucky; the other 110 thousand board feet came from Indiana's forestland.

\section{PULPWOOD}

- Indiana's pulpwood production (including both roundwood and mill residues generated by the State's other primary woodusing industries) has been increasing over time except in 1990 (table 8).

- In 1995, pulpwood production in Indiana totaled more than 310 thousand cords of roundwood and mill residues, a 64-percent increase from 1990. Much of the increase was concentrated in hardwood residues.

- Mill residues supplied more than 85 percent of the pulpwood produced in 1995.
- Indiana's pulpwood and particleboard mills consumed more than 68 percent of the State's production of pulpwood. The remainder was shipped out of State for processing in the Southern States, Northeastern States, and Lake States (table A).

- Hard hardwoods was the major species group of roundwood pulpwood exported in 1995.

- The Knobs Unit provided more than twothirds of the roundwood pulpwood harvested in the State in 1995 (table 9).

- Three counties-Greene, Owen, and Perryeach reported harvesting more than 5 thousand cords of roundwood pulpwood in 1995. 


\begin{tabular}{|c|c|c|c|c|c|c|c|c|}
\hline \multirow[b]{2}{*}{$\begin{array}{l}\text { Forest } \\
\text { Survey } \\
\text { Reqions }\end{array}$} & \multicolumn{3}{|c|}{ Roundwood } & \multirow[b]{2}{*}{ Total } & \multicolumn{3}{|c|}{ Residues } & \multirow[b]{2}{*}{$\begin{array}{c}\text { All } \\
\text { wood } \\
\text { material }\end{array}$} \\
\hline & $\begin{array}{l}\text { Soft- } \\
\text { woods }\end{array}$ & $\begin{array}{l}\text { Soft } \\
\text { hard- } \\
\text { woods }\end{array}$ & $\begin{array}{l}\text { Hard } \\
\text { hard- } \\
\text { woods }\end{array}$ & & $\begin{array}{l}\text { Soft- } \\
\text { woods }\end{array}$ & $\begin{array}{l}\text { Hard- } \\
\text { woods }\end{array}$ & Total & \\
\hline & $-\quad-\quad-$ & $-\quad-\quad-$ & $-\quad(\ln s$ & andard & s, unpee & ed) - - & $-\quad-$ & $-\quad-\quad-$ \\
\hline Central States & - & 5.4 & 19.9 & 25.3 & 35.3 & 151.9 & 187.2 & 212.5 \\
\hline Lake States & - & - & 一 & 一 & - & 14.2 & 14.2 & 14.2 \\
\hline Northeastern States & s 3.6 & * & * & 3.6 & - & 2.4 & 2.4 & 6.0 \\
\hline Southern States & $=$ & - & 15.6 & 15.6 & $\star$ & 62.2 & 62.2 & 77.8 \\
\hline Total & 3.6 & 5.4 & 35.5 & 44.5 & 35.3 & 230.7 & 266.0 & 310.5 \\
\hline
\end{tabular}

* $=$ Less than 50 cords.

' Pulpwood Production in the North-Central Region, 1995, RB-NC-180.

Pulpwood is a major product in the North Central Region. A yearly study is done of all pulpmills and particleboard mills in the region. A separate publication, "Pulpwood Production in the North-Central Region, 1995," by Ronald $J$. Piva, RB-NC-180, is available from the North Central Research Station.

\section{VENEER LOGS}

- Between 1990 and 1995, veneer log production in Indiana increased by more than 41 percent (table 10). At the same time veneer log receipts increased by more than onethird, from 35 million board feet in 1990 to 47 million in 1995.

- Black walnut veneer log production declined by 43 percent between 1990 and 1995; this was offset by increases in red and white oak, and black cherry for the same time period. Black walnut receipts at mills in Indiana decreased by 40 percent, from 5 million board feet in 1990 to 3 million board feet in 1995. This decline in the use of black walnut was offset by increased use of yellow-poplar, hard maple, and ash.

- Indiana retained nearly three-quarters of the veneer log volume it harvested in 1995 (table 11) (fig. 6). The remaining onequarter was shipped out of State for processing, mostly to neighboring Ohio and other States outside the region.
- The white oak group was the major species of veneer log exported from Indiana.

- Nearly two-thirds of all the veneer log and bolt volume was produced in the Knobs Unit (table 12).

- Indiana supplied more than 37 percent of the State's veneer log requirements in 1995 (table 13). Another 35 percent was provided by other States outside the region, and the remaining 28 percent was provided by Michigan, Kentucky, Illinois, Ohio, surrounding States, and Canada.

- Red and white oak, black cherry, and hard maple make up nearly two-thirds of the veneer log volume processed in the State. More than 68 percent of these four species combined were imported from neighboring and other States outside the region.

\section{OTHER PRODUCTS}

- Loggers cut more than 300 thousand cubic feet of other industrial roundwood products in Indiana in 1995, almost all of which was cooperage logs.

- Cooperage log harvesting occurred mainly in the Knobs and Upland Flats Units-all white oak (1.8 million board feet).

- An estimated 136 thousand cubic feet of roundwood was cut from Indiana's forest in 1995 for building log cabins. 


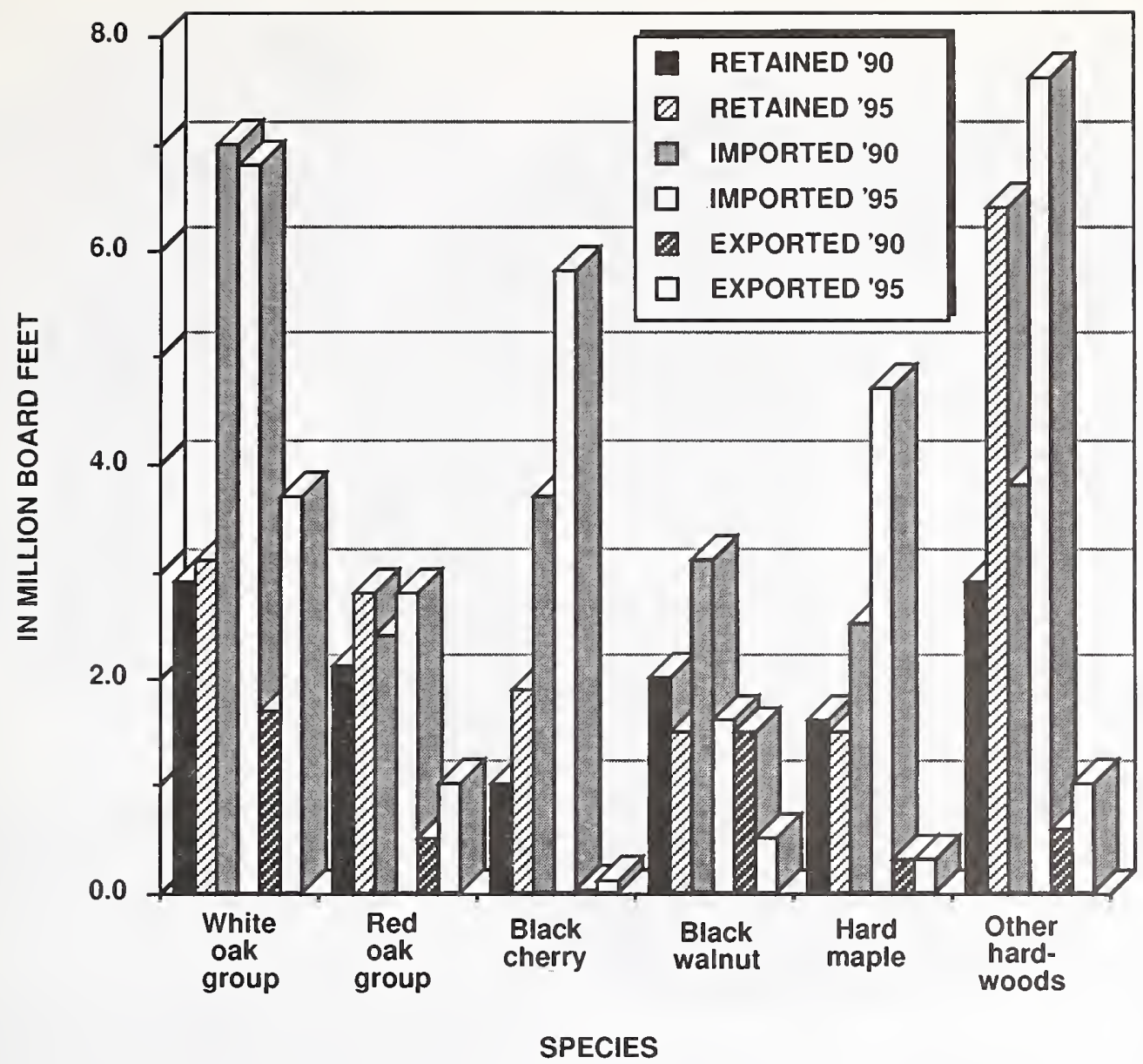

Figure 6.-Veneer log and bolt production retained, imported, and exported (to mills outside Indiana) by select species in Indiana, 1990 and 1995.

- The remaining volume prduced in the State was a small amount of oak and honeylocust ( 12 cords) used as industrial fuelwood at a rendering plant.

Residential fuelwood is a nonindustrial product in Indiana. The results of a residential fuelwood study conducted in 1996 are available in a separate Station publication, "Residential fuelwood consumption and production in Indiana, 1996," by Dennis M. May, Jeff Settle, and Tamara Benjamin, RB-NC-188, is available from the North Central Research Station.

\section{TIMBER REMOVALS}

- In 1995, loggers harvested more than 116.5 million cubic feet of wood material from Indiana's forest (table 14).
- More than 77 million cubic feet of the total 116.5 million cubic feet was cut from the growing-stock inventory on Indiana's timberland, a decrease of nearly 20 percent from 1990 (fig. 7).

- Nearly 40 percent of the growing-stock removals came from the Knobs Unit, the region of the State where production of saw logs and veneer logs is concentrated (table 15).

- Red and white oak accounted for more than 43 percent of all growing-stock removals.

- Industrial roundwood harvesting also removed more than 407 million board feet of wood from the sawtimber portion of the growing-stock inventory in 1995 (table 16), a decrease of nearly 20 percent from 1990. 


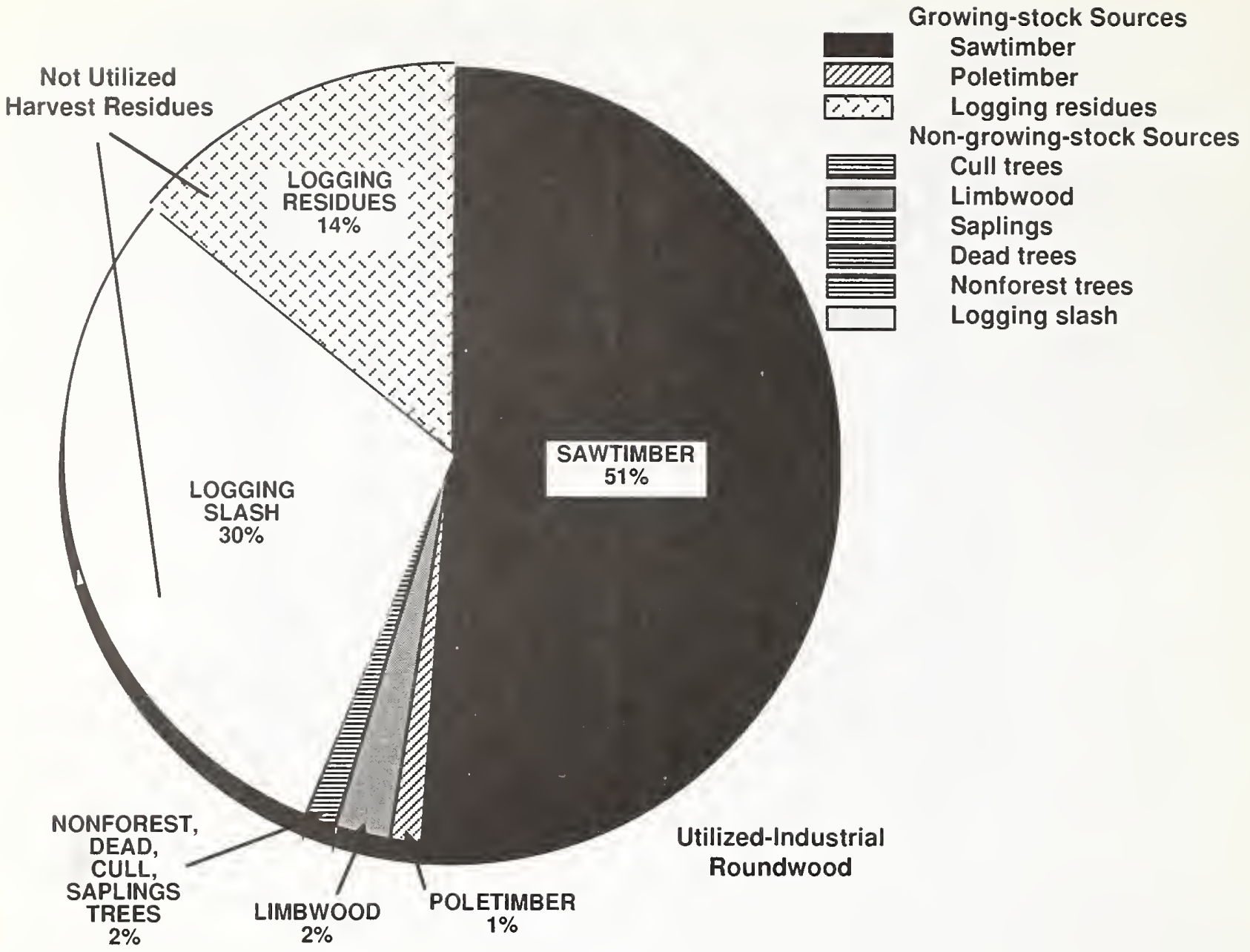

Figure 7.-Distribution of timber removals for industrial roundwood by source of material, Indiana, 1995.

- Nearly 40 percent of all sawtimber removals occurred in the Knobs Unit, the area of the State where saw-log production is concentrated.

- Sawtimber removals were concentrated in four species-red oak, white oak, yellowpoplar, and ash-which together accounted for more than two-thirds of all sawtimber removals. Red and white oak accounted for more than 43 percent of all sawtimber removals.

\section{HARVEST RESIDUES}

- In 1995, harvesting of industrial roundwood products left more than 51 million cubic feet of harvest residues on the ground (table 17), a decrease of nearly 20 percent from 1990 , generally due to the decrease in harvesting of saw logs in 1995.
- The Knobs Unit had more than 37 percent of the harvest residues in the State in 1995. The Lower Wabash and Northern Units had more than 27 percent each of harvest residues in the State.

- Four species-red oak, white oak, yellowpoplar, and ash-accounted for more than two-thirds of all harvest residues.

\section{PRIMARY MILL RESIDUE}

- In converting industrial roundwood into milled products, such as lumber, sheathing, and wood pulp, Indiana's primary woodusing industry generated 1.2 million green tons of wood and bark residues (table 18).

- Coarse and bark wood residues together made up three-quarters of the total volume in 1995; fine wood residue made up the remainder (fig. 8). 


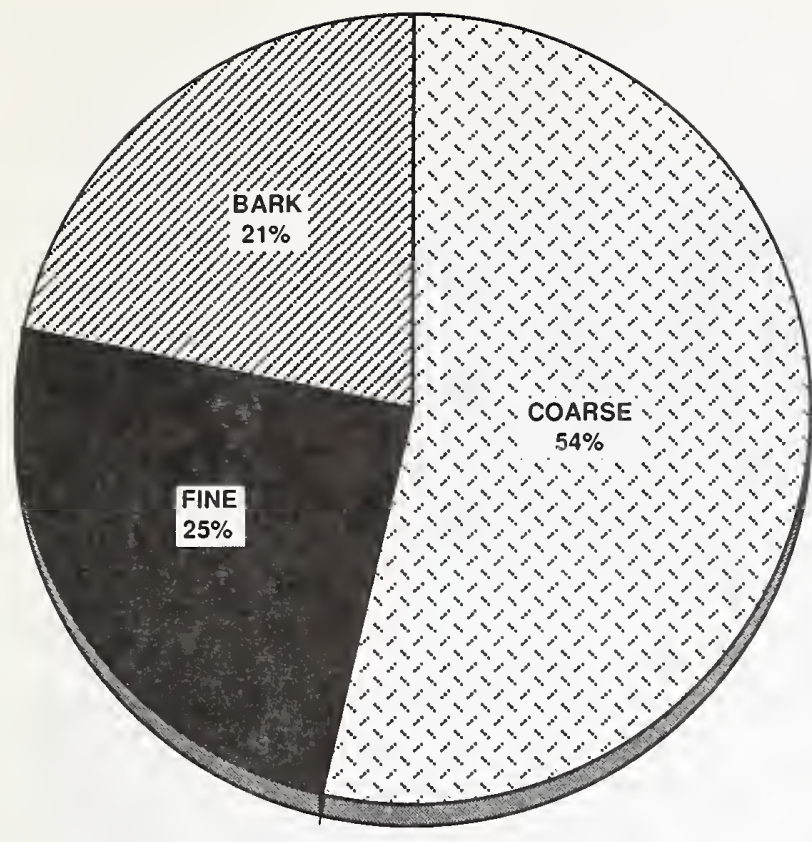

Figure 8.-Distribution of residues generated by primary wood-using mills by type of residue, Indiana, 1995.

- Almost all the mill residues were used; 40 percent ended up as miscellaneous products such as mulch and animal bedding (fig. 9).

- In general, most coarse wood residues were used for fiber products such as pulpwood or particleboard. Most fine and bark residues were used for miscellaneous products such as mulch and animal bedding.

- More than two-thirds of the mill residues were generated in the Knobs and Northern Units combined, and more than 43 percent of all unused mill residues were located in the Northern Unit.

\section{REGIONAL TRENDS}

\section{Knobs Unit}

- In 1995, more than 26 million cubic feet of roundwood was produced in the 17 counties that make up the Knobs Unit of Indiana; this accounted for more than 40 percent of the State's total output.

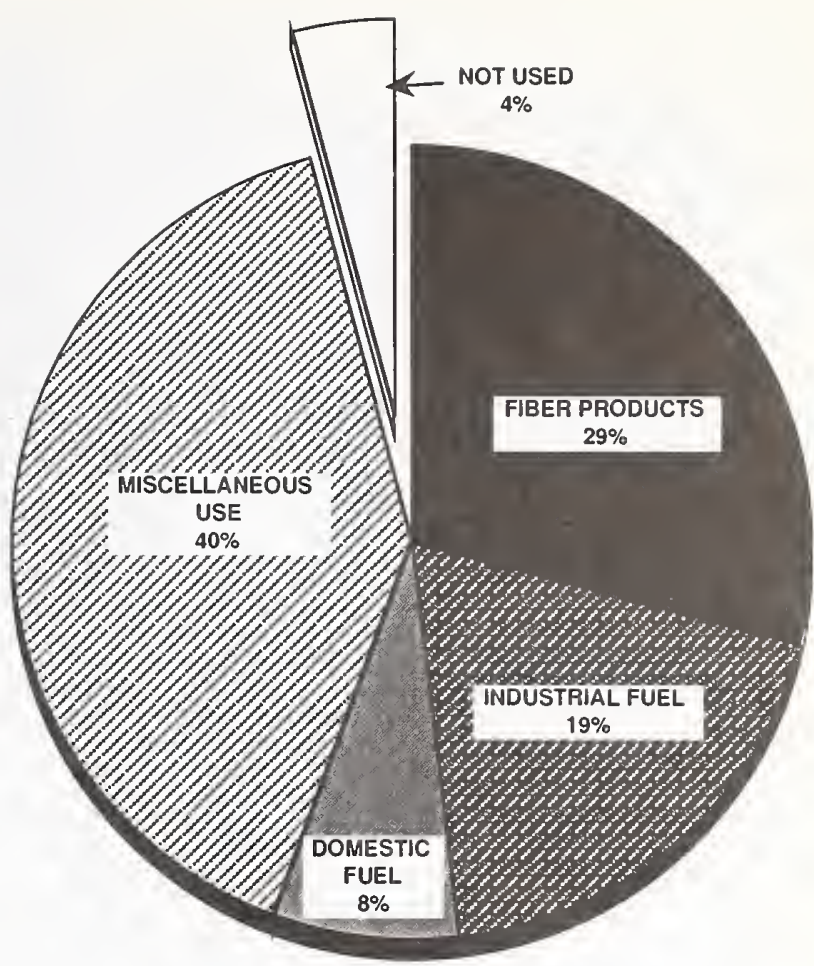

Figure 9.-Distribution of residues generated by primary wood-using mills by method of disposal, Indiana, 1995.

- The 26 million cubic feet of industrial roundwood reflects a 30-percent decline between 1990 and 1995 .

- Saw-log production of more than 21 million cubic feet accounted for more than fourfifths of the total roundwood production in this unit, reflecting a 10-percent decline from 1990.

- Veneer log production tripled from 1990 to 1995-from 690 thousand cubic feet to more than 2 million cubic feet. It accounted for more than 7 percent of the unit's total roundwood output.

- Pulpwood production increased by nearly 15 percent from 1990 to 1995 and accounted for more than 7 percent of the unit's total roundwood output.

- The Knobs Unit produced nearly 38 percent of the State's saw logs, nearly 63 percent of the veneer logs, more than 66 percent of the pulpwood, and nearly 79 percent of the cooperage logs (fig. 10). 


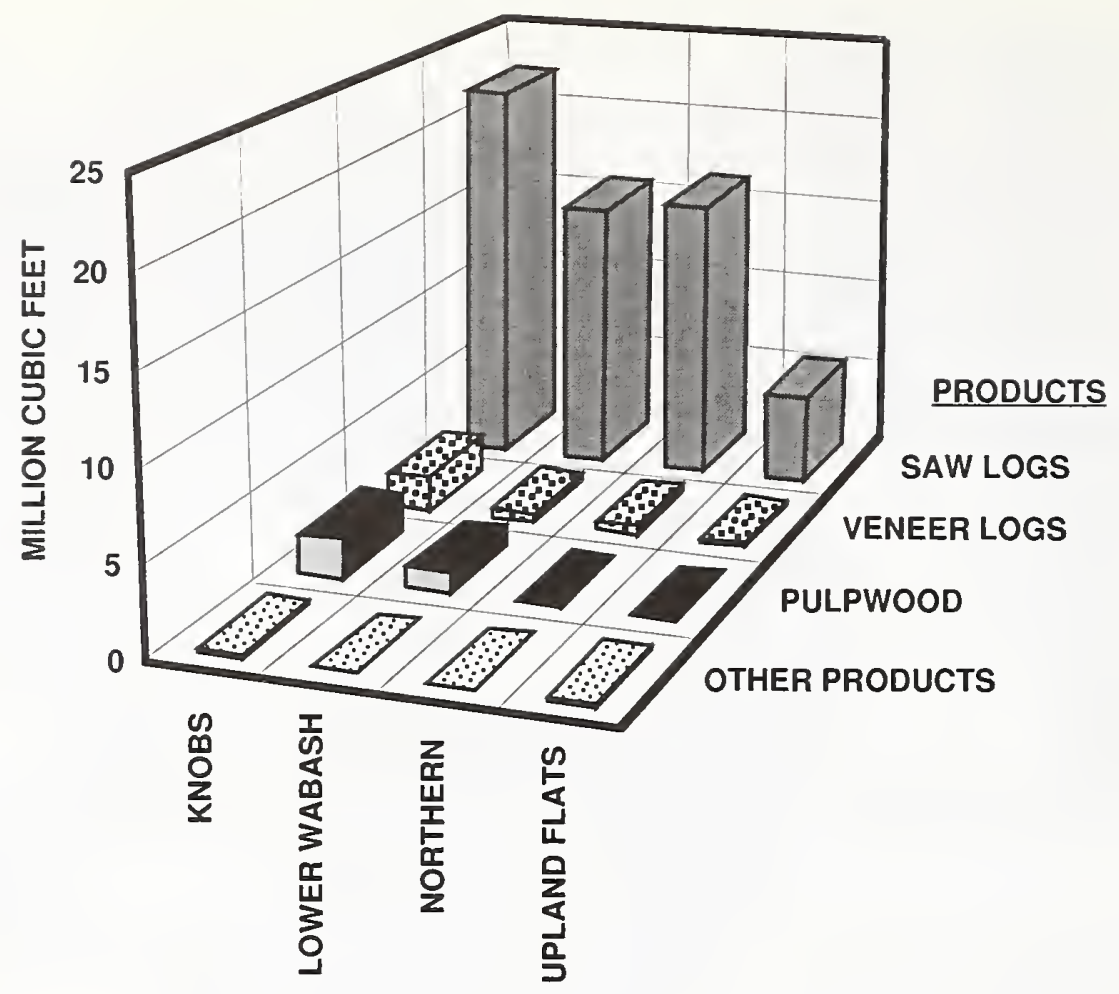

FOREST SURVEY UNITS

Figure 10.-Distribution of roundwood products harvested by unit, Indiana, 1995.

- In 1995, the Knobs Unit had 74 sawmills, 5 veneer mills, 2 particleboard mills, and 1 miscellaneous mill.

- Nearly 60 percent of the sawmills in the region had receipts greater than 1 million board feet, while 28 percent of the mills had less than 500 thousand board feet of receipts.

\section{Lower Wabash Unit}

- Between 1990 and 1995, roundwood production from the 14 counties that make up the Lower Wabash Unit decreased by 2 percent to 17 million cubic feet.

- This unit accounted for more than 26 percent of the State's total roundwood output in 1995, an increase of 5 percent from 1990.

- Saw-log production of more than 15 million cubic feet accounted for more than 90 percent of the total roundwood production in this unit.
- Veneer log production increased by more than 30 percent between 1990 and 1995 . and accounted for nearly 3 percent of the unit's total roundwood output in 1995.

- Pulpwood production between 1990 and 1995 increased by more than 14 percent and accounted for more than 6 percent of the unit's total roundwood output.

- The Lower Wabash Unit produced more than 26 percent of the saw logs, more than 15 percent of the veneer logs, more than 31 percent of the pulpwood, and nearly 3 percent of the cooperage logs in the State.

- In 1995, 34 mills including 30 sawmills, 2 veneer mills, 1 pulpmill, and 1 miscellaneous mill operated in the Lower Wabash Unit.

- Only 22 sawmills in the Lower Wabash Unit had receipts of more than 1 million board feet, while 20 percent of the mills had receipts less than 500 thousand board feet. 


\section{Northern Unit}

- The 52-county Northern Unit produced the third largest amount of roundwood in the State. In 1995, this unit produced almost 17 million cubic feet of industrial roundwood, 10 percent less than in 1990. Total production of industrial roundwood was more than one-quarter of the State's total industrial roundwood output.

- Saw-log production of more than 16 million cubic feet accounted for nearly 97 percent of the total roundwood produced in this unit in 1995.

- Veneer log production decreased by more than 43 percent between 1990 and 1995, and accounted for nearly 3 percent of the unit's total roundwood output in 1995.

- Pulpwood production increased from none in 1990 to 79 thousand cubic feet in 1995 , and accounted for less than 1 percent of the unit's total roundwood output in 1995.

- The Northern Unit produced nearly 27 percent of the State's saw logs, more than 14 percent of the veneer logs, and more than 2 percent of the pulpwood produced in 1995.

- In 1995, 75 sawmills and 5 veneer mills operated in the Northern Unit.

- Nearly half of the sawmills in the Northern Unit had receipts of 1 million board feet or more, while more than 40 percent of the mills had receipts of less than 500 thousand board feet.

\section{Upland Flats Unit}

- In 1995, the nine counties that make up the Upland Flats Unit produced more than 5 million cubic feet of industrial roundwood, nearly 18 percent less than in 1990. Total production of industrial roundwood in 1995 was nearly 8 percent of the State's total industrial roundwood output.

- Saw-log production decreased by 10 percent between 1990 and 1995 to 4.9 million cubic feet, this volume accounted for more than 94 percent of the unit's industrial roundwood production.

- Veneer log production declined by more than 41 percent from 1990 to 230 thousand cubic feet of roundwood output in 1995.

Veneer log production accounted for more than 4 percent of the unit's total roundwood output.

- Cooperage log production quadrupled to 56 thousand cubic feet in 1995; this volume accounted for more than 1 percent of the unit's roundwood output.

- The Upland Flats Unit produced more than 8 percent of the State's saw logs, 7 percent of the veneer logs, and more than 18 percent of the cooperage logs.

- In 1995, 13 sawmills operated in the Upland Flats Unit.

- More than 38 percent of the sawmills in the unit had receipts of more than 1 million board feet; more than 46 percent of the mills had receipts of less than 500 thousand board feet.

\section{APPENDIX}

\section{STUDY METHODS}

This study was a cooperative effort of the Indiana Department of Natural Resources (IDNR) and the North Central Research Station (NCRS). Using mail questionnaires supplied by NCRS and designed to determine the size and composition of the State's primary woodusing industry, its use of roundwood, and its generation and disposition of wood residues, the IDNR canvassed all primary wood-using mills within the State. The IDNR followed up on nonresponding mills by using additional mailings, telephone, and personal contacts until a 100-percent response was achieved. Completed questionnaires were sent to NCRS for editing and processing.

As part of data editing and processing, all industrial roundwood volumes reported on the questionnaires were converted to standard units of measure using regional conversion factors. Timber removals by source of material and harvest residues generated during logging 
were estimated from standard product volumes using factors developed from logging utilization studies previously conducted by NCRS. Finalized data on Indiana's industrial roundwood receipts were loaded into a regional timber removals data base and supplemented with data on out-of-State uses of Indiana roundwood to provide a complete assessment of Indiana's timber product output.

\section{DEFINITION OF TERMS}

Board foot.-Unit of measure applied to roundwood. It relates to lumber that is 1 foot long, 1 foot wide, and 1 inch thick (or its equivalent).

Bolt.-A short log, no more than 16 to 20 feet long, to be sawn for lumber or peeled for veneer.

Central stem.-The portion of a tree between a 1-foot stump and the minimum 4.0-inch top diameter outside bark, or point where the central stem breaks into limbs.

Coarse mill residue.-Wood residue suitable for chipping such as slabs, edgings, and veneer cores.

Commercial species.-Tree species presently or prospectively suitable for industrial wood products. (Note: Excludes species of typically small size, poor form, or inferior quality such as hophornbeam, Osage-orange, and redbud.)

Cull removals.-Net volume of rough and rotten trees plus the net volume in sections of the central stem of growing-stock trees that do not meet regional merchantability standards, harvested for industrial roundwood products.

Dead removals. - Net volume of dead trees harvested for industrial roundwood products.

Diameter at breast height (d.b.h.).-The outside bark diameter at 4.5 feet above the forest floor on the uphill side of the tree. For determining breast height, the forest floor includes the duff layer that may be present, but does not include unincorporated woody debris that may rise above the ground line.
Fine mill residue.-Wood residue not suitable for chipping such as sawdust and veneer clippings.

Forest land.-Land at least 16.7 percent stocked by forest trees of any size, or formerly having had such tree cover, and not currently developed for nonforest use. (Note: Stocking is measured by comparing specified standards with basal area and/or number of trees, age or size, and spacing.) The minimum area for classification of forest land is 1 acre. Roadside, streamside, and shelterbelt strips of timber must have a crown width of at least 120 feet to qualify as forest land. Unimproved roads and trails, streams, or other bodies of water or clearings in forest areas shall be classed as forest if less than 120 feet wide.

Growing-stock removals.-The growing-stock volume removed from the timberland inventory by harvesting industrial roundwood products. (Note: Includes sawtimber removals, poletimber removals, and logging residues.)

Growing-stock tree.-A live timberland tree of commercial species that meets specified standards of size, quality, and merchantability. (Note: Excludes rough, rotten, and dead trees.)

Growing-stock volume.-Net volume of growing-stock trees 5.0 inches d.b.h. and over, from 1 foot above the ground to a minimum 4.0-inch top diameter outside bark of the central stem or the point where the central stem breaks into limbs.

Hardwoods.-Dicotyledonous trees, usually broad-leaved and deciduous.

Harvest residues. - The total net volume of unused portions of trees cut or killed by logging. (Note: Includes both logging residues and logging slash.)

Industrial roundwood products.-Saw logs, pulpwood, veneer logs, poles, commercial posts, piling, cooperage logs, particleboard bolts, shaving bolts, lath bolts, charcoal bolts, and chips from roundwood used for pulp or board products. 
Industrial roundwood exports. - The quantity of industrial roundwood harvested in a geographical area and transported to other geographical areas.

Industrial roundwood imports.-The quantity of industrial roundwood received from other geographical areas.

Industrial roundwood production.-The quantity of industrial roundwood harvested in a geographic area plus all industrial roundwood exported to other geographical areas.

Industrial roundwood receipts.-The quantity of industrial roundwood harvested for commercial mills in a geographic area plus all industrial roundwood imported from other geographical areas.

Industrial roundwood retained.-The quantity of industrial roundwood harvested from and processed by commercial mills within the same geographical area.

International $\mathbf{1}$ /4-inch rule. - A log rule or formula for estimating the board foot volume of logs, allowing 1/2-inch of taper for each 4foot length. The rule appears in a number of forms that allow for kerf. In the form used by FIA, a 1/4-inch of kerf is assumed. This rule is used as the USDA Forest Service standard log rule in the Eastern United States.

Limbwood removals-Net volume of all portions of a tree other than the central stem, (including forks, large limbs, tops, and stumps) harvested for industrial roundwood products.

Logging residue.-The net volume of unused portions of the merchantable central stem of growing-stock trees cut or killed by logging.

Logging slash.-The net volume of unused portions of the unmerchantable (non-growing-stock) sections of trees cut or killed by logging.

Merchantable sections.-Refers to sections of the central stem of growing-stock trees that meet either pulpwood or saw-log specifications.
Net volume.-Gross volume less deductions for rot, sweep, or other defects affecting use for roundwood products.

Noncommercial species.-Tree species of typically small size, poor form, or inferior quality that normally do not develop into trees suitable for industrial roundwood products. Classified in volume tables as rough trees.

Nonforest land.-Land that has never supported forests, and land formerly forested where use for timber management is precluded by development for other uses. (Note: Includes areas used for crops, orchards, Christmas trees, improved pasture, residential areas, city parks, improved roads of any width and adjoining clearings, powerline clearings of any width, and 1- to 39.9-acre areas of water classified by the Bureau of the Census as land. If intermingled in forest areas, improved roads and nonforest strips must be more than 120 feet wide and more than 1 acre to qualify as nonforest land.)

Nonforest land removals.-Net volume of trees on nonforest lands harvested for industrial roundwood products.

Poletimber.-A growing-stock tree at least 5.0 inches d.b.h. but smaller than sawtimber size (9.0 inches d.b.h. for softwoods, 11.0 inches d.b.h. for hardwoods).

Poletimber removals.-Net volume in the merchantable central stem of poletimber trees harvested for industrial roundwood products.

Primary wood-using mills.-Mills receiving roundwood or chips from roundwood for processing into products.

Primary wood-using mill residue.-Wood materials (coarse and fine) and bark generated at manufacturing plants from roundwood processed into principal products. These residues include wood products (byproducts) obtained incidental to production of principal products and wood materials not utilized for some product. 
Rotten tree.-A tree that does not meet regional merchantability standards because of excessive unsound cull.

Rough tree.-A tree that does not meet regional merchantability standards because of excessive sound cull. Includes noncommercial tree species.

Roundwood.-Logs, bolts, or other round sections cut from trees (including chips from roundwood).

Sapling.-A live tree between 1.0 and 5.0 inches d.b.h.

Sapling removals. - Net volume in saplings harvested for industrial roundwood products.

Saw-log portion.-That portion of the central stem of sawtimber trees between the stump and the saw-log top.

Saw-log top.-The point on the central stem of sawtimber trees above which a saw log cannot be produced. The minimum saw-log top is 7.0 inches d.o.b. for softwoods and 9.0 inches d.o.b. for hardwoods.

Sawtimber removals.-As used in table 14, sawtimber removals refers to the net volume in the merchantable central stem of sawtimber trees harvested for industrial roundwood products. (Note: Includes the saw-log and upper stem portions of sawtimber trees.) When referring to the sawtimber volume removed from the timberland inventory as in table 16, sawtimber removals refers to the net volume in the saw-log portion of sawtimber trees harvested for roundwood products or left on the ground as harvest residue, and is usually expressed in thousands of board feet (International 1/4-inch rule).

Sawtimber tree.-A growing-stock tree containing at least a 12 -foot saw log or two noncontiguous saw logs 8 feet or longer, and meeting regional specifications for freedom from defect. Softwoods must be at least 9.0 inches d.b.h. and hardwoods must be at least 11.0 inches d.b.h.

Sawtimber volume.-Net volume in the saw$\log$ portion of sawtimber trees.
Softwoods. - Coniferous trees, usually evergreen, having needles or scale-like leaves.

Timber product output.-The volume of roundwood products produced from an area's forests.

Timberland.-Forest land that is producing, or is capable of producing, in excess of 20 cubic feet per acre per year of industrial roundwood products under natural conditions, is not withdrawn from timber utilization by statute or administrative regulation, and is not associated with urban or rural development.

Tree.-A woody plant usually having one or more perennial stems, a more or less definitely formed crown of foliage, and a height of at least 12 feet at maturity.

Upper stem portion.-That portion of the central stem of sawtimber trees between the saw-log top and the minimum top diameter of 4.0 inches outside bark or the point where the central stem breaks into limbs.

Veneer log or bolt.-A log or bolt used in the production of plywood, finished panels, containers, or veneer sheets, both rotary cut and sliced.

\section{COMMON AND SCIENTIFIC NAMES OF TREE SPECIES MENTIONED IN THIS REPORT}

\section{SOFTWOODS}

Pine

Shortleaf pine ...................... Pinus echinata Virginia pine ...................... Pinus virginiana Eastern white pine ................. Pinus strobus Red pine ............................. Pinus resinosa Scotch pine ...................... Pinus sylvestris Cypress ........................ Taxodium distichum Eastern redcedar ............ Juniperus virginiana

\section{HARDWOODS}

White oak

White oak ............................ Quercus alba Swamp white oak ................ Quercus bicolor Bur oak ..................... Quercus macrocarpa Swamp chestnut oak ....... Quercus michauxii Chinkapin oak.......... Buercus muehlenbergii Chestnut oak ..................... Quercus prinus Post oak ......................... Quercus stellata Red oak 
Northern red oak Quercus rubra

Cherrybark oak Quercus falcata var. pagodaefolia

Shumard oak Quercus shumardii

Black oak . Quercus velutina

Scarlet oak Quercus coccinea

Southern red oak - Guercus falcata

Shingle oak Quercus imbricaria

Pin oak Quercus palustris

Hickory

Mockernut hickory

Carya tomentosa

Shagbark hickory

Shellbark hickory

Pecan Carya ovata

Pignut hickory ... Carya laciniosa . Carya illinoensis

Bitternut hickory

Hard maple

Soft maple

Red maple Acer rubrum

Silver maple Acer saccharinum

Beech Fagus grandifolia

Sweetgum

Blackgum

Tupelo

. Carya glabra

Carya cordiformis . Acer saccharum

Black tupelo .... Nyssa sylvatica var. sylvatica Swamp tupelo ..... Nyssa sylvatica var. biflora Ash

White ash Fraxinus americana

Black ash Fraxinus nigra

Green ash

Blue ash Liquidambar styraciflua Nyssa sylvatica Cottonwood

Aspen

Bigtooth aspen

Quaking aspen

Populus grandidentata Populus tremuloides

American basswood Tilia americana

Yellow-poplar

Black cherry Liriodendron tulipifera Fraxinus pennsylvanica Fraxinus quadrangulata Populus deltoides

Black walnut

Elm Prunus serotina Juglans nigra

Winged elm Ulmus alata

American elm Ulmus americana

Siberian elm Ulmus pumila

Slippery elm Ulmus rubra

Rock elm Ulmus thomasii

American sycamore Birch

Yellow birch

River birch

Paper birch

Other hardwoods

Ohio buckeye

Hackberry Aesculus glabra Northern catalpa Celtis occidentalis Flowering dogwood Catalpa speciosa Common persimmon ..... Diospyros virginiana Honeylocust Gleditsia triacanthos Kentucky coffeetree ...... Gymnocladus dioicus
Butternut Juglans cinerea

Osage-orange Maclura pomifera

Cucumbertree Magnolia acuminita

Black locust Robinia pseudoacacia

Black willow Salix nigra

Sassafras Sassafras albidum

Boxelder Acer negundo

Balsam poplar Populus balsamifera

\section{TABLE TITLES}

Table 1.-Number of active primary woodusing mills, Indiana, 1980, 1984, 1990, and 1995

Table 2.-Industrial roundwood receipts by type of mill in Indiana, 1966, 1984, 1990 , and 1995

Table 3.--Industrial roundwood production by Forest Survey Unit, species group, and type of product, Indiana, 1995

Table 4.-Saw-log production and receipts in Indiana by species group, 1990 and 1995

Table 5.-Saw-log production by Forest Survey Unit, county, and species group, Indiana, 1995

Table 6.-Saw-log production by Forest Survey Unit, species group, and State of destination, Indiana, 1995

Table 7.-Saw-log receipts by Forest Survey Unit, species group, and State of origin, Indiana, 1995

Table 8.-Pulpwood production in Indiana by species group, 1966, 1976, 1984, 1990, and 1995

Table 9.-Roundwood pulpwood production by Forest Survey Unit and species group, Indiana, 1995

Table 10.-Veneer log and bolt production in Indiana by species group, 1966 , 1976, 1984, 1990, and 1995

Table 11.- Veneer log and bolt production by Forest Survey Unit, species group, and destination, Indiana, 1995

Table 12.-Veneer log and bolt production by Forest Survey Unit, county, and species group, Indiana, 1995 
Table 13.- Veneer log and bolt receipts by Forest Survey Unit, species group, and State of origin, Indiana, 1995

Table 14.-Wood material harvested for industrial roundwood by Forest Survey Unit, source of material, and species group, Indiana, 1995

Table 15.-Growing-stock removals from timberland for industrial roundwood by Forest Survey Unit, county, and species group, Indiana, 1995
Table 16.-Sawtimber removals from timberland for industrial roundwood by Forest Survey Unit, county, and species group. Indiana, 1995

Table 17.- - Harvest residues generated by industrial roundwood harvesting from timberland by Forest Survey Unit, county, and species group, Indiana, 1995

Table 18.- Residue produced at primary woodusing mills by type of material, type of use, and Forest Survey Unit, Indiana, 1995

Table 1.--Number of active primary wood-using mills, Indiana, 1980, 1984, 1990, and 1995

\begin{tabular}{lllll}
\hline Kind of mill & 1980 & 1984 & 1990 & 1995 \\
\hline
\end{tabular}

Sawmills 1/

Total

\begin{tabular}{lrrrr} 
Large 2/ & 99 & 112 & 126 & 108 \\
Medium 3/ & 59 & 47 & 25 & 20 \\
Small 4/ & 176 & 117 & 95 & 64 \\
\cline { 2 - 5 } & 334 & 276 & 246 & 192
\end{tabular}

\begin{tabular}{lrrrr} 
Pulp mills & 1 & 1 & 1 & 3 \\
Veneer mills & 16 & 16 & 14 & 12 \\
Other mills 5/ & 16 & 13 & 9 & 2 \\
\cline { 2 - 5 } Total & 367 & 306 & 270 & 209 \\
\hline
\end{tabular}

1/ Includes four handle plants.

2) Annual lumber production in excess of 1 million board feet.

3/ Annual lumber production from 1/2 million to 1 million board feet.

4/ Annual lumber production to 1/2 million board feet.

5/ Includes shavings, cabin logs, excelsior, cooperage, and handle plants. 
Table 2.--Industrial roundwood receipts by type of mill in Indiana, 1966, 1984, 1990, and 1995

(In million cubic feet)

\begin{tabular}{|c|c|c|c|c|}
\hline \multicolumn{5}{|c|}{ All species } \\
\hline Kind of mill & 1966 & 1984 & 1990 & 1995 \\
\hline Saw logs & 32.8 & 58.9 & 72.6 & 67.7 \\
\hline Pulpwood & 6.8 & 2.8 & 3.0 & 1.3 \\
\hline Veneer logs & 2.2 & 1.9 & 2.3 & 6.0 \\
\hline Other products $1 /$ & 3.6 & 2.0 & 2.2 & 0.9 \\
\hline Total & 45.4 & 65.6 & 80.1 & 75.9 \\
\hline \multicolumn{5}{|c|}{ Hardwoods } \\
\hline Saw logs & 32.6 & 58.7 & 72.6 & 67.4 \\
\hline Pulpwood & 6.7 & 2.8 & 3.0 & 1.3 \\
\hline Veneer logs & 2.2 & 1.9 & 2.3 & 6.0 \\
\hline Other products $1 /$ & 3.6 & 2.0 & 2.1 & 0.9 \\
\hline Total & 45.1 & 65.4 & 80.0 & 75.6 \\
\hline \multicolumn{5}{|c|}{ Softwoods } \\
\hline Saw logs & 0.2 & 0.2 & $2 /$ & 0.2 \\
\hline Pulpwood & 0.1 & .. & -- & $2 /$ \\
\hline Veneer logs & -- & $2 /$ & $2 /$ & $2 /$ \\
\hline Other products $1 /$ & $\cdots$ & .. & 0.1 & - \\
\hline Total & 0.3 & 0.2 & 0.1 & 0.2 \\
\hline
\end{tabular}

1/ Includes logs and bolts used for handles, mine timbers, cooperage, and other products.

2/ Less than 50 thousand cubic feet. 


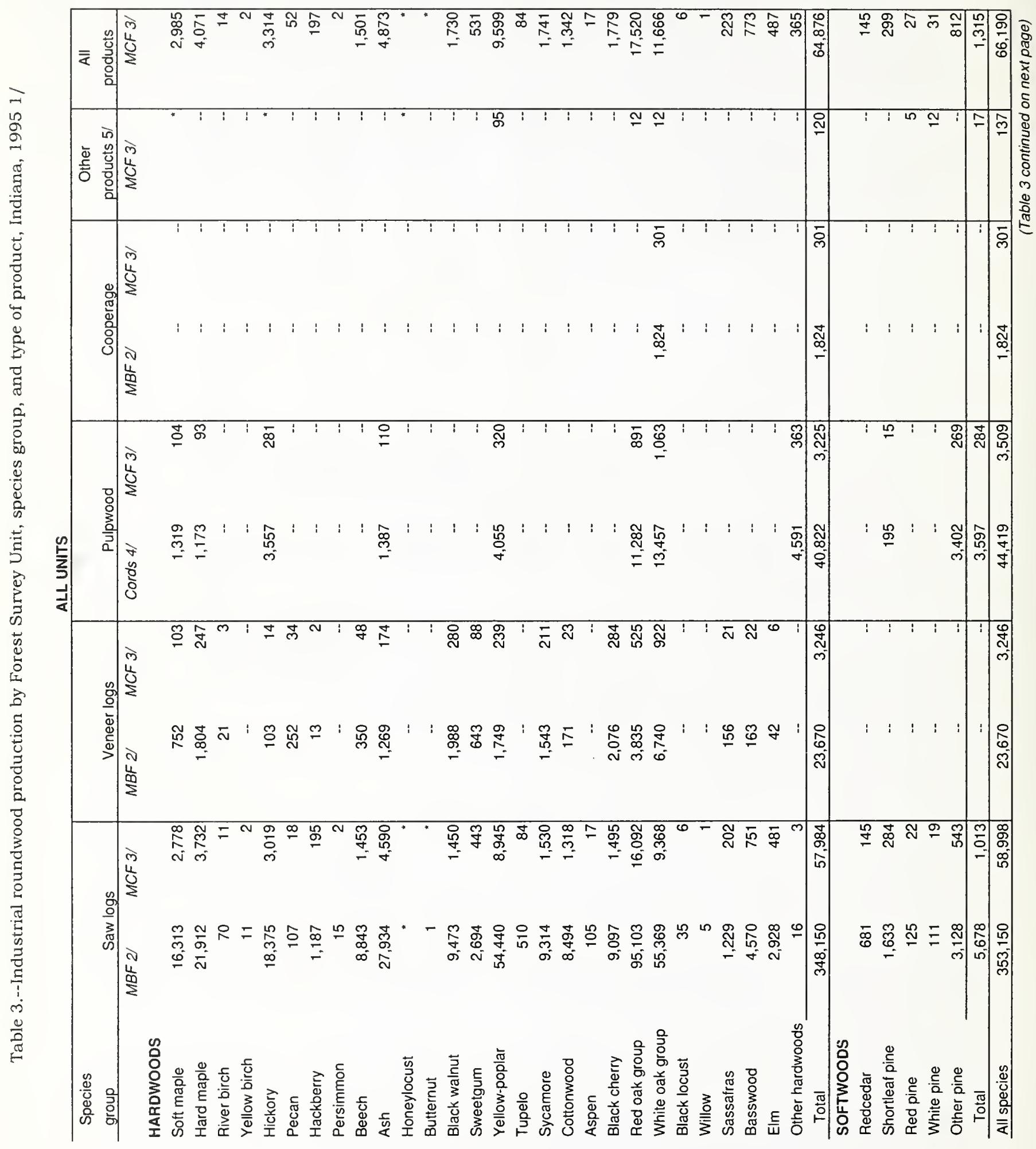




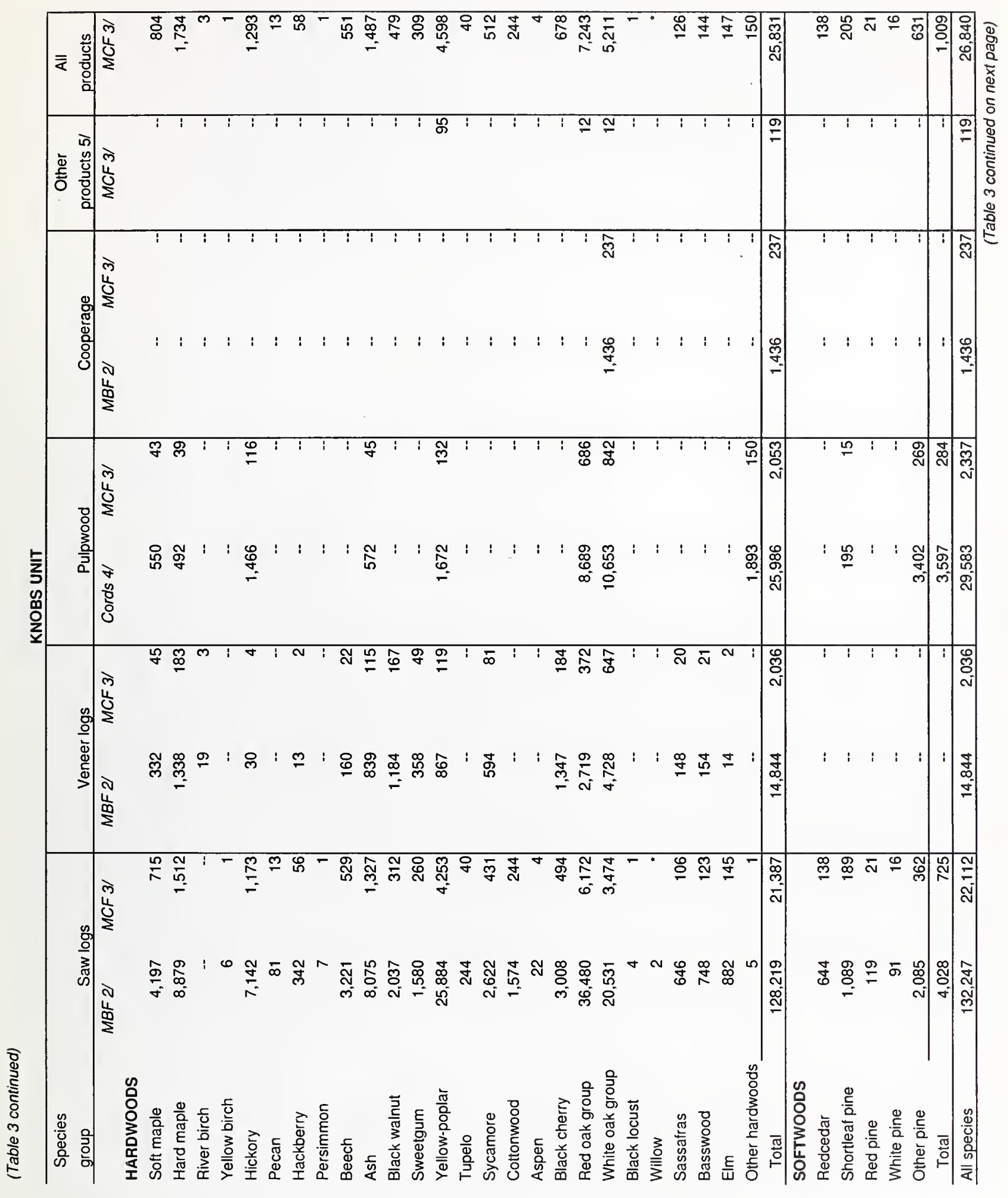




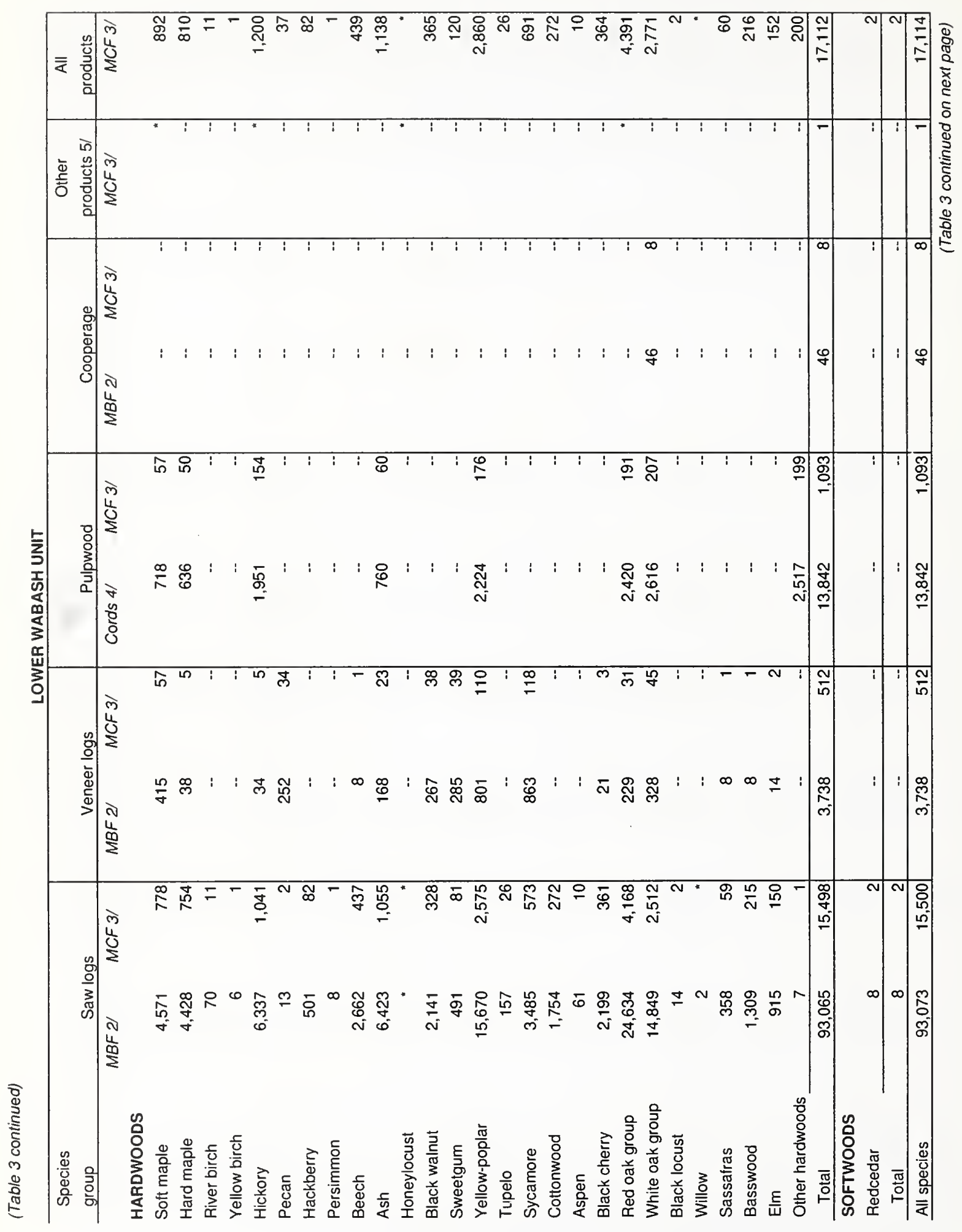




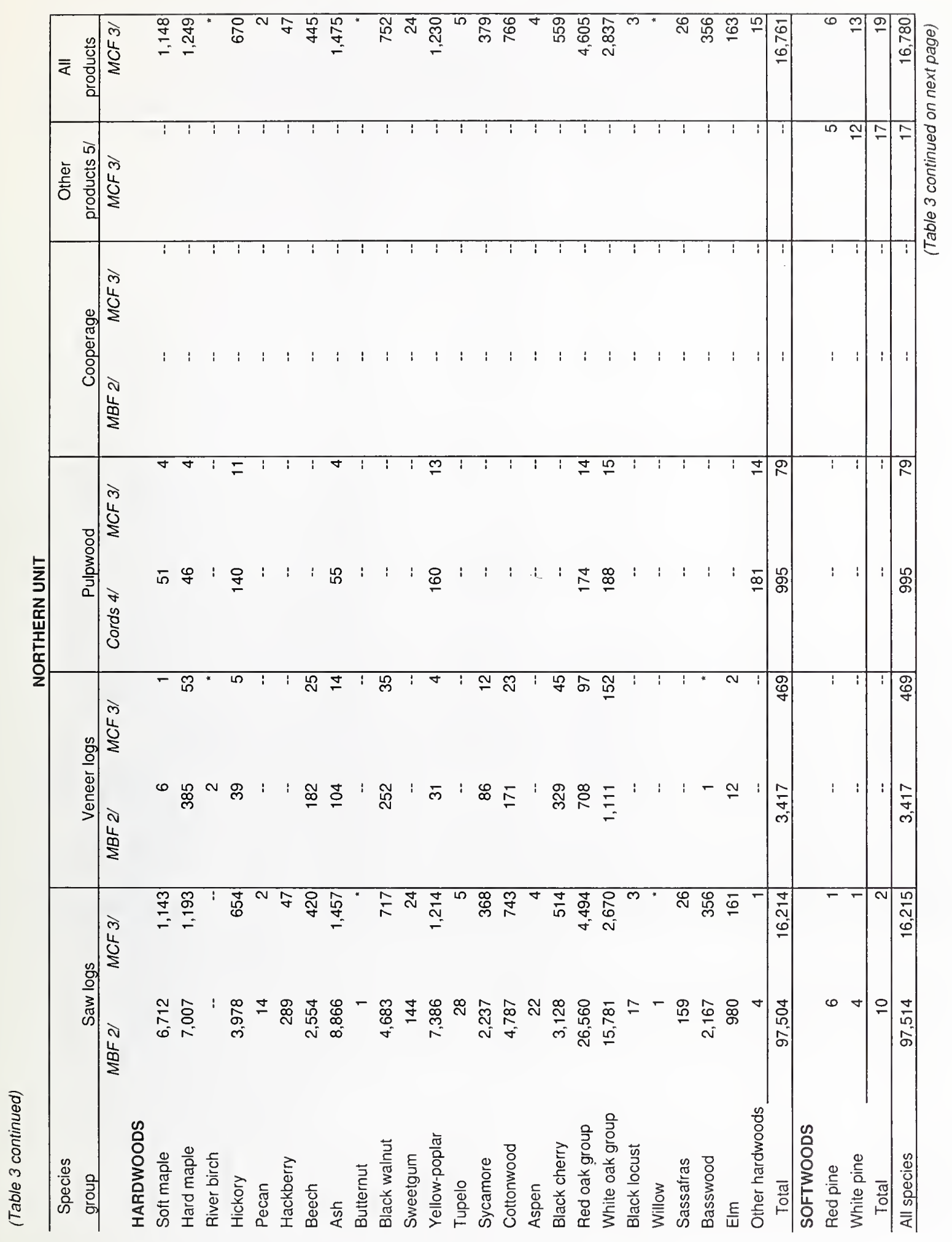




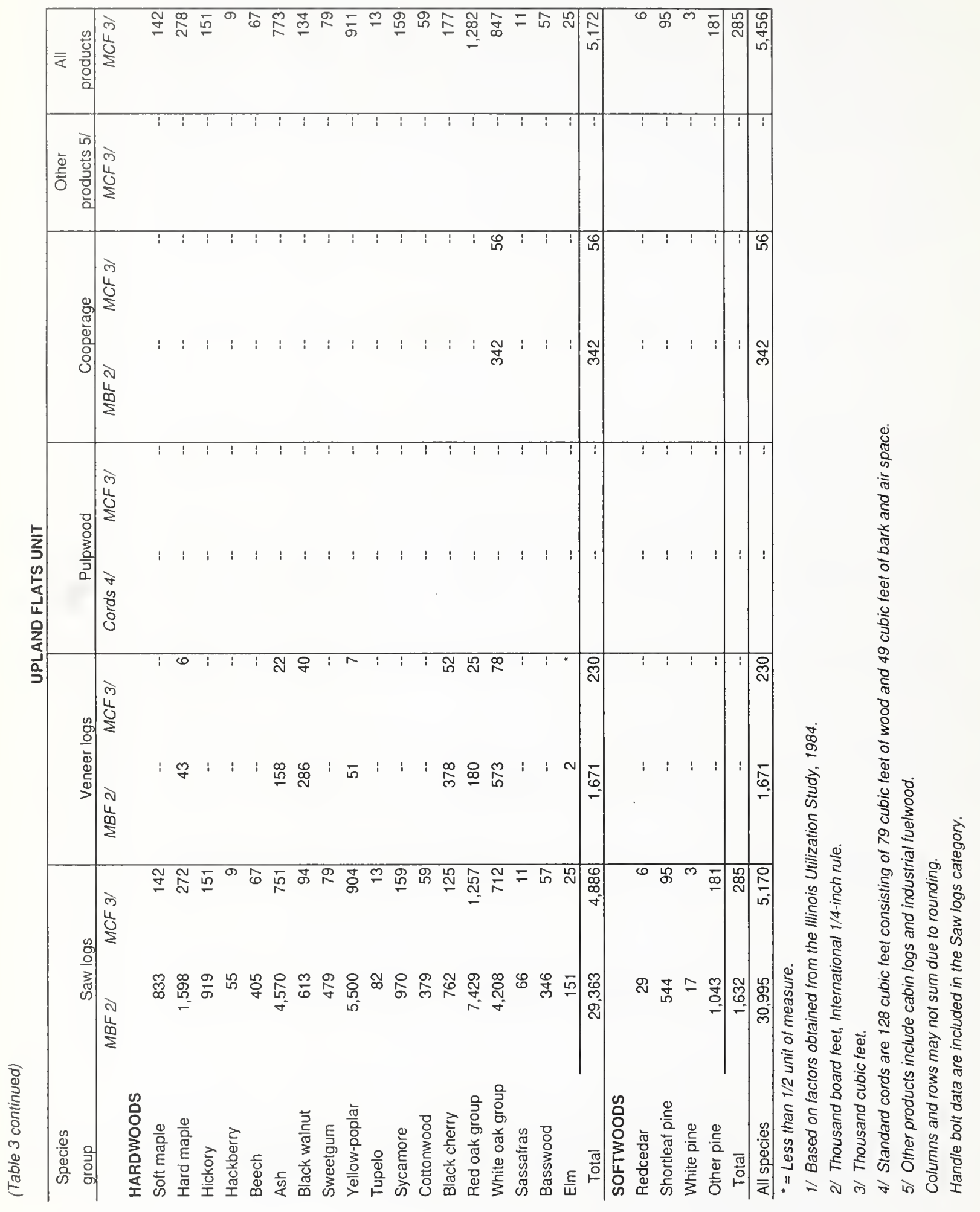


Table 4.--Saw-log production and receipts in Indiana by species group, 1990 and 1995 (In thousand board feet) $1 /$

\begin{tabular}{|c|c|c|c|c|c|c|}
\hline \multirow[b]{2}{*}{ Species group } & \multicolumn{3}{|c|}{ Production } & \multicolumn{3}{|c|}{ Receipts } \\
\hline & 1990 & 1995 & Change & 1990 & 1995 & Change \\
\hline \multicolumn{7}{|l|}{ HARDWOODS } \\
\hline Ash & 29,995 & 27,934 & $-2,061$ & 35,431 & 32,752 & $-2,679$ \\
\hline Aspen & 637 & 105 & -532 & 655 & 116 & -539 \\
\hline Basswood & 3,998 & 4,570 & 572 & 5,088 & 5,158 & 70 \\
\hline Beech & 11,001 & 8,843 & $-2,158$ & 12,063 & 9,804 & $-2,259$ \\
\hline Birch & 250 & 81 & -169 & 327 & 10 & -317 \\
\hline Blackgum & 1,597 & 510 & $-1,087$ & 1,557 & 160 & $-1,397$ \\
\hline Black cherry & 10,377 & 9,097 & $-1,280$ & 12,420 & 10,828 & $-1,592$ \\
\hline Cottonwood & 8,963 & 8,494 & -469 & 9,378 & 9,814 & 436 \\
\hline Elm & 1,506 & 2,928 & 1,422 & 1,937 & 3,226 & 1,289 \\
\hline Pecan & 1,287 & 107 & $-1,180$ & 1,528 & 107 & $-1,421$ \\
\hline Hickory & 21,221 & 18,375 & $-2,846$ & 25,392 & 21,039 & $-4,353$ \\
\hline Hard maple & 20,682 & 21,912 & 1,230 & 24,174 & 25,693 & 1,519 \\
\hline Soft maple & 16,110 & 16,313 & 203 & 21,094 & 21,130 & 36 \\
\hline Red oak group & 143,263 & 95,103 & $-48,160$ & 166,435 & 107,119 & $-59,316$ \\
\hline White oak group & 64,617 & 55,369 & $-9,248$ & 76,294 & 63,554 & $-12,740$ \\
\hline Sweet gum & 4,088 & 2,694 & $-1,394$ & 4,118 & 3,144 & -974 \\
\hline Sycamore & 12,480 & 9,314 & $-3,166$ & 14,191 & 10,269 & $-3,922$ \\
\hline Black walnut & 10,196 & 9,473 & -723 & 13,705 & 10,597 & $-3,108$ \\
\hline Yellow-poplar & 72,504 & 54,440 & $-18,064$ & 79,805 & 60,111 & $-19,694$ \\
\hline Other hardwoods & 707 & 2,489 & 1,782 & 735 & 2,895 & 2,160 \\
\hline Total & 435,419 & 348,151 & $-87,268$ & 506,327 & 397,526 & $-108,801$ \\
\hline \multicolumn{7}{|l|}{ SOFTWOODS } \\
\hline Pine & 289 & 4,997 & 4,708 & 317 & 305 & -12 \\
\hline Redcedar & 100 & 681 & 581 & 107 & 686 & 579 \\
\hline Total & 389 & 5,678 & 5,289 & 424 & 991 & 567 \\
\hline All species & 435,808 & 353,829 & $-81,979$ & 506,751 & 398,518 & $-108,233$ \\
\hline
\end{tabular}




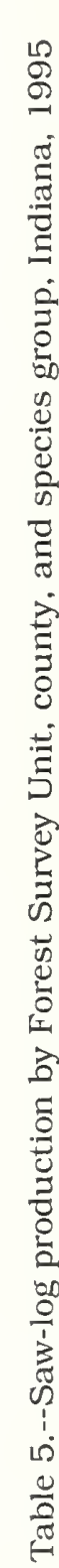

总壳|

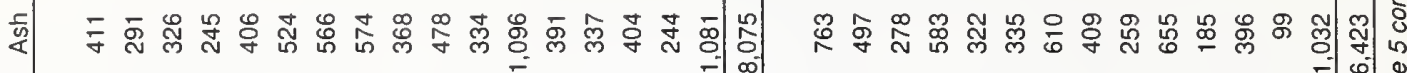

总

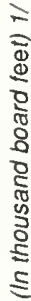

产

亲 츔

ล 马ํำ

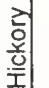

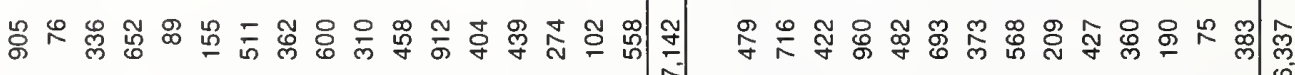

흘 돈

：：N：：：

: $: \wedge: \quad: \quad: \quad: \wedge \bar{\infty}$

은

$\sum_{i=\frac{1}{x}}^{\overline{0}}$

高

인

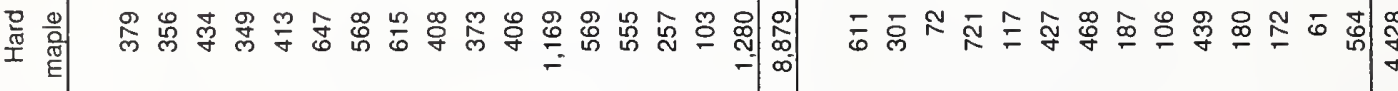

क

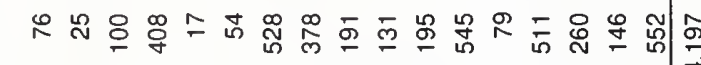

.

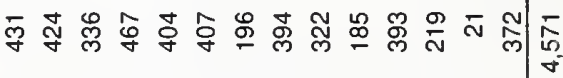

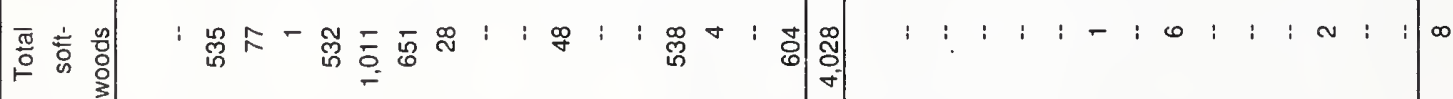

:

产

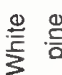

:

(

$\underset{\mathbb{2}}{\mathbb{2}}$

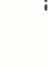

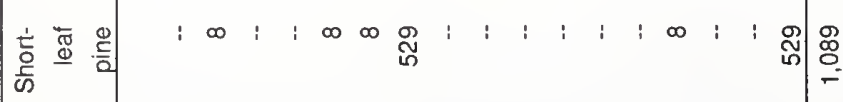

要 


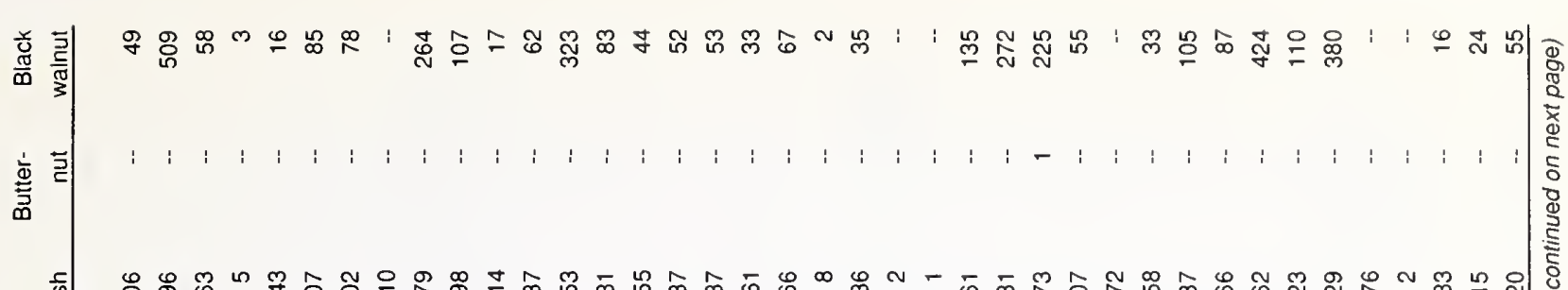

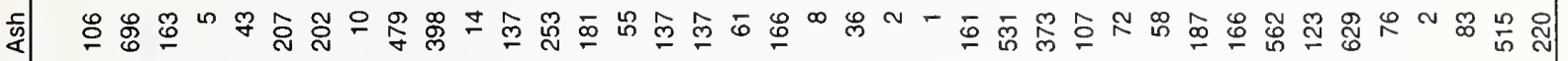

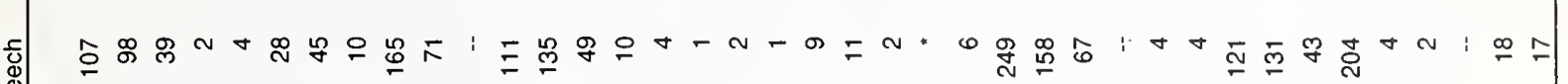

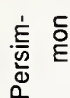

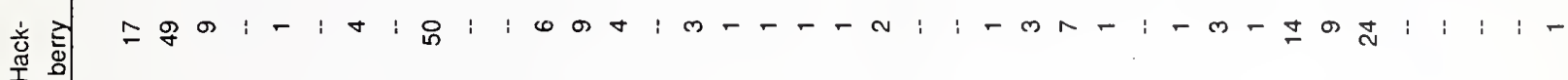

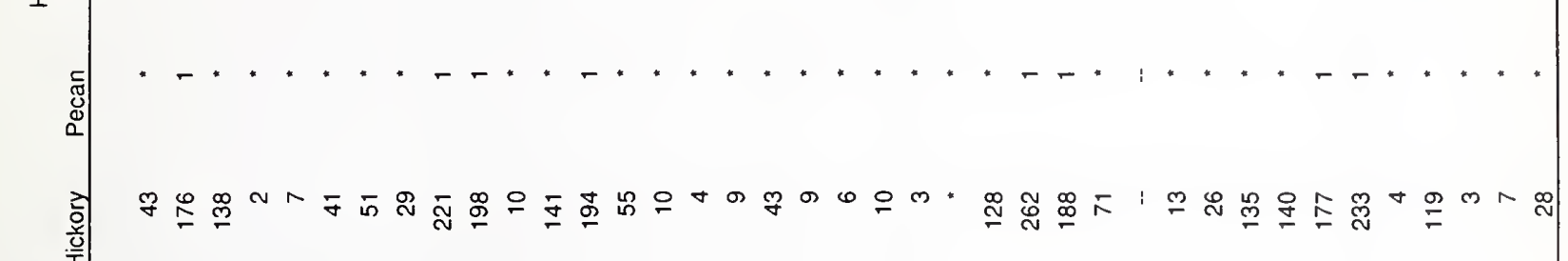

흥

产

뮴 임

产 弟

홓

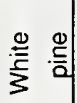

욤

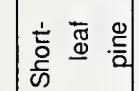

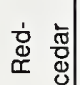

年

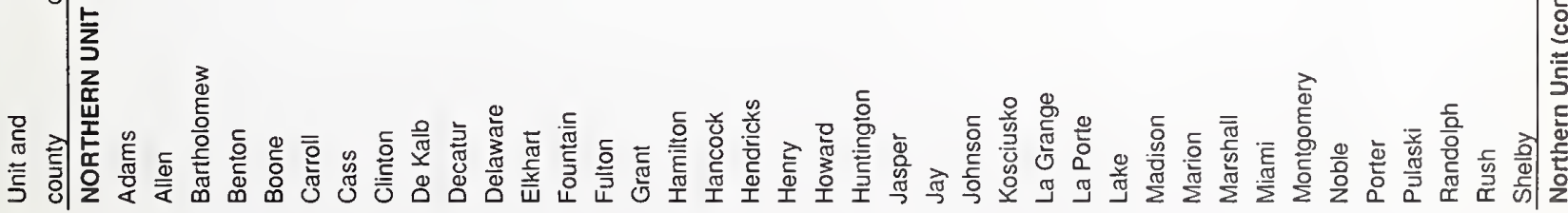

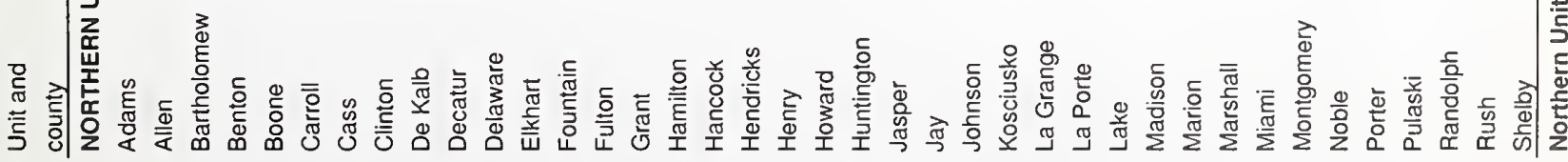




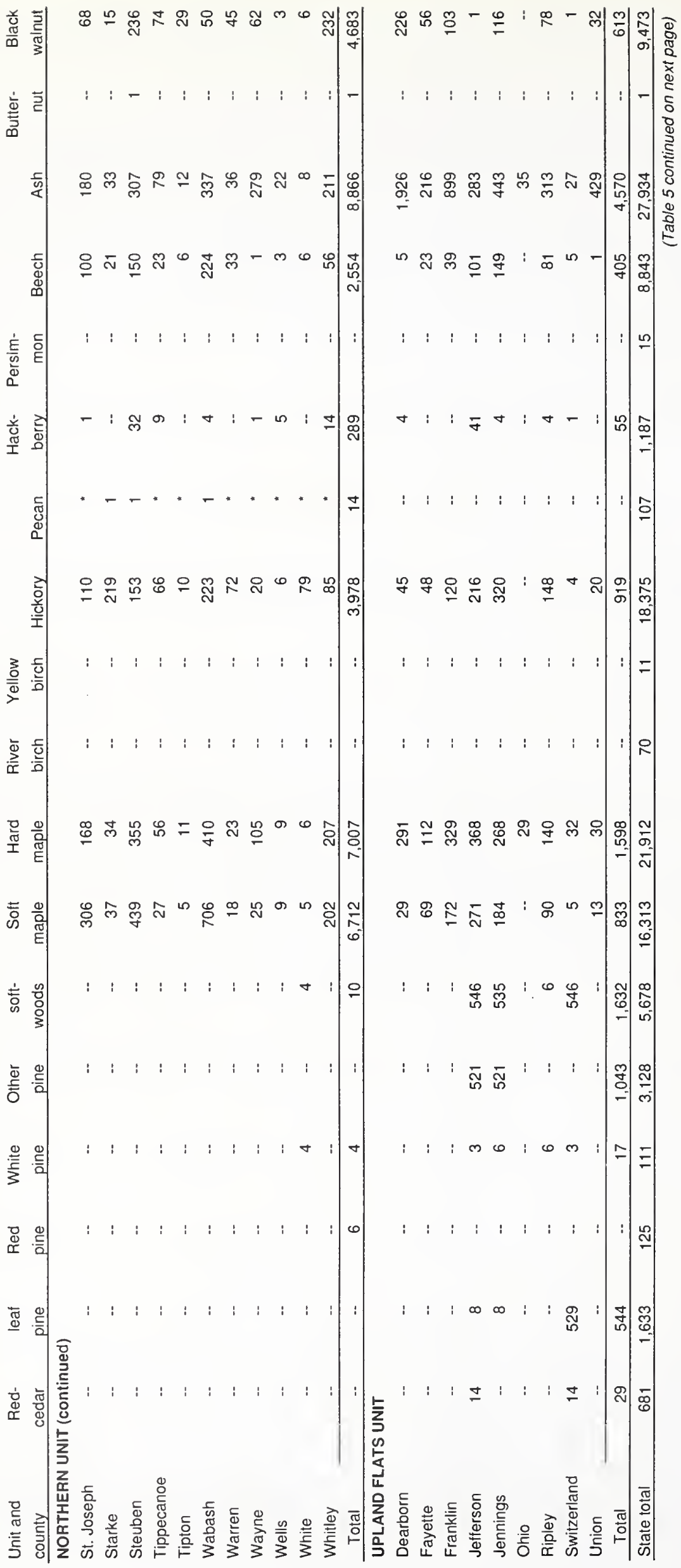




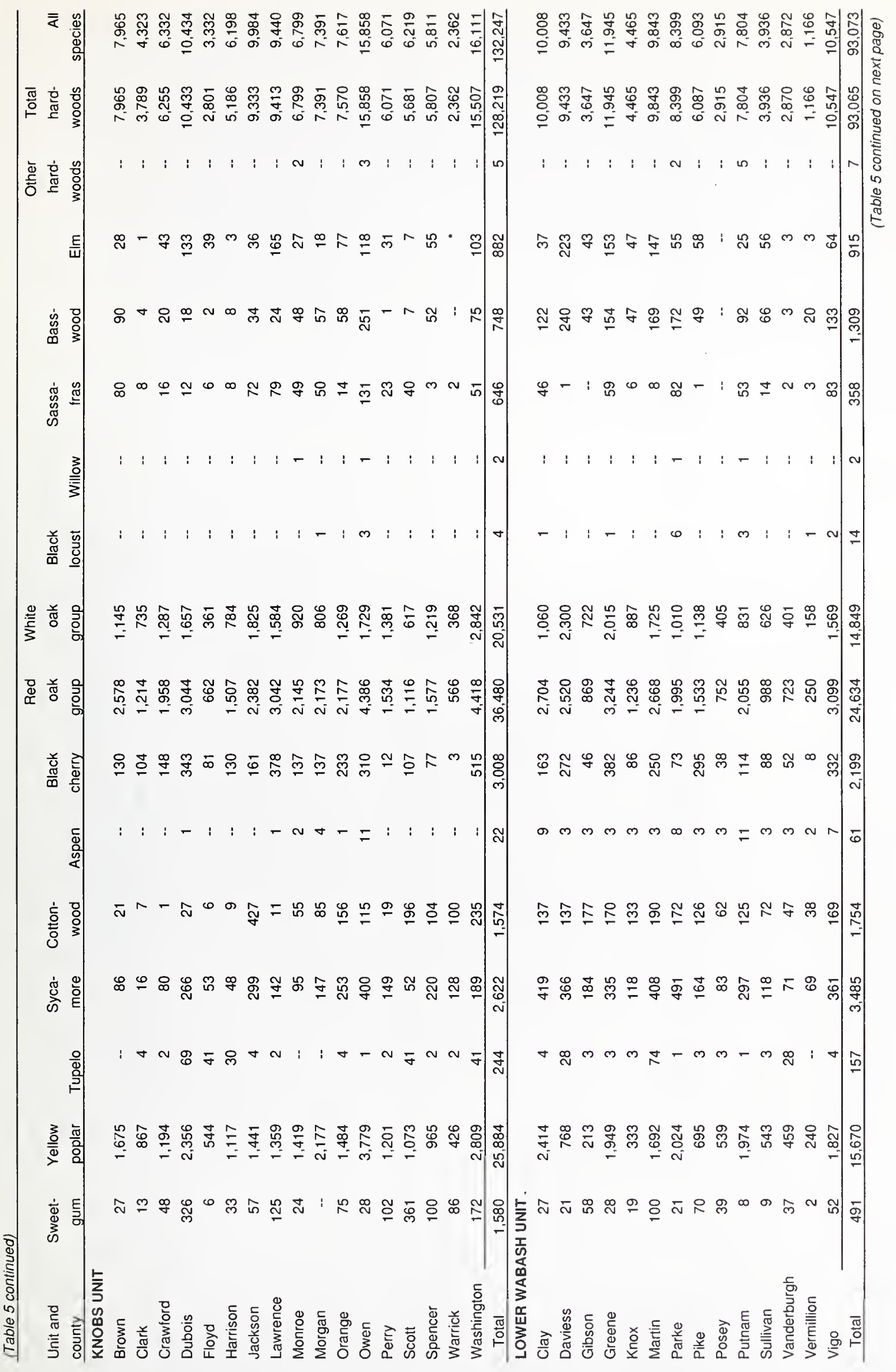




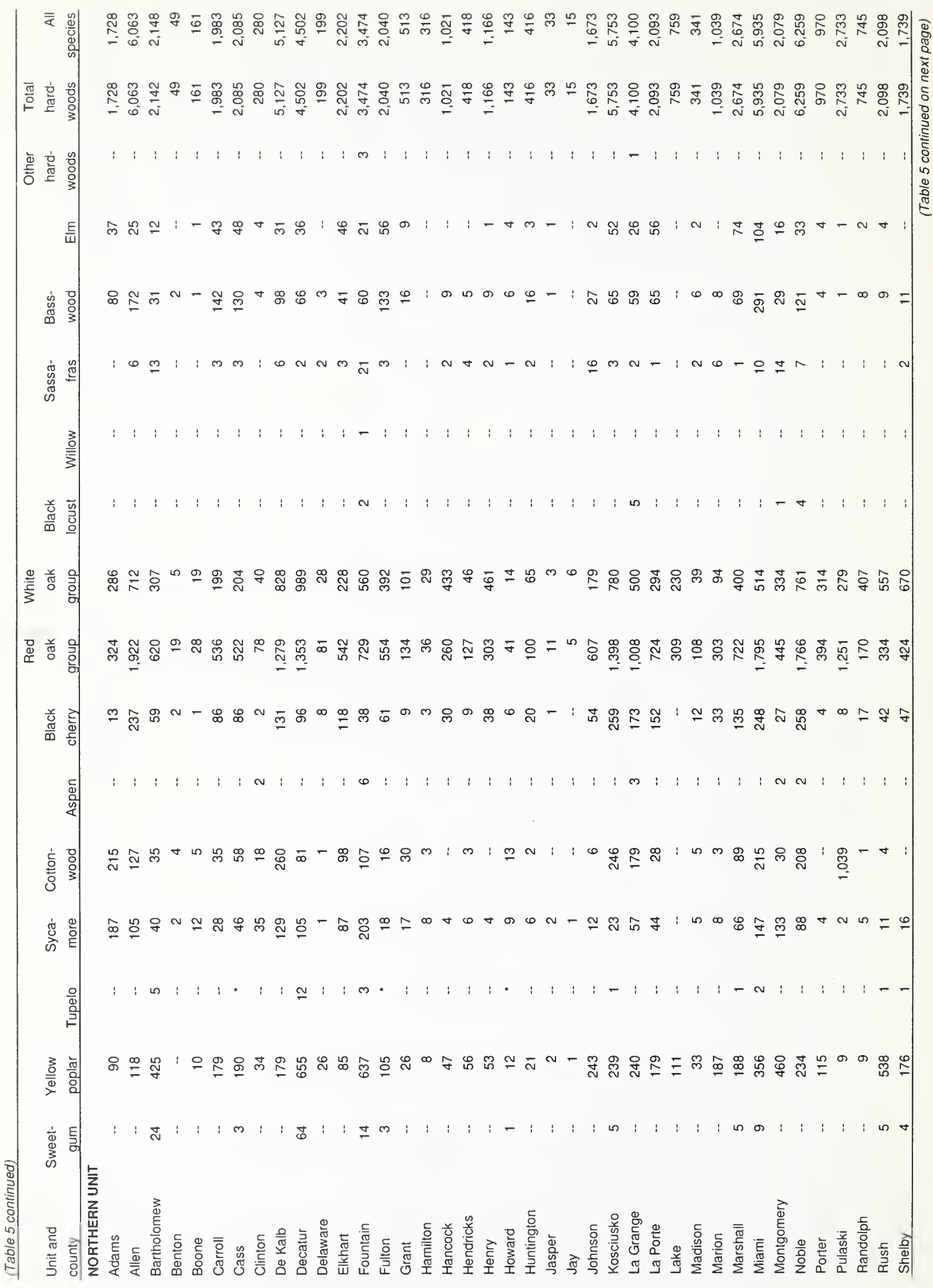




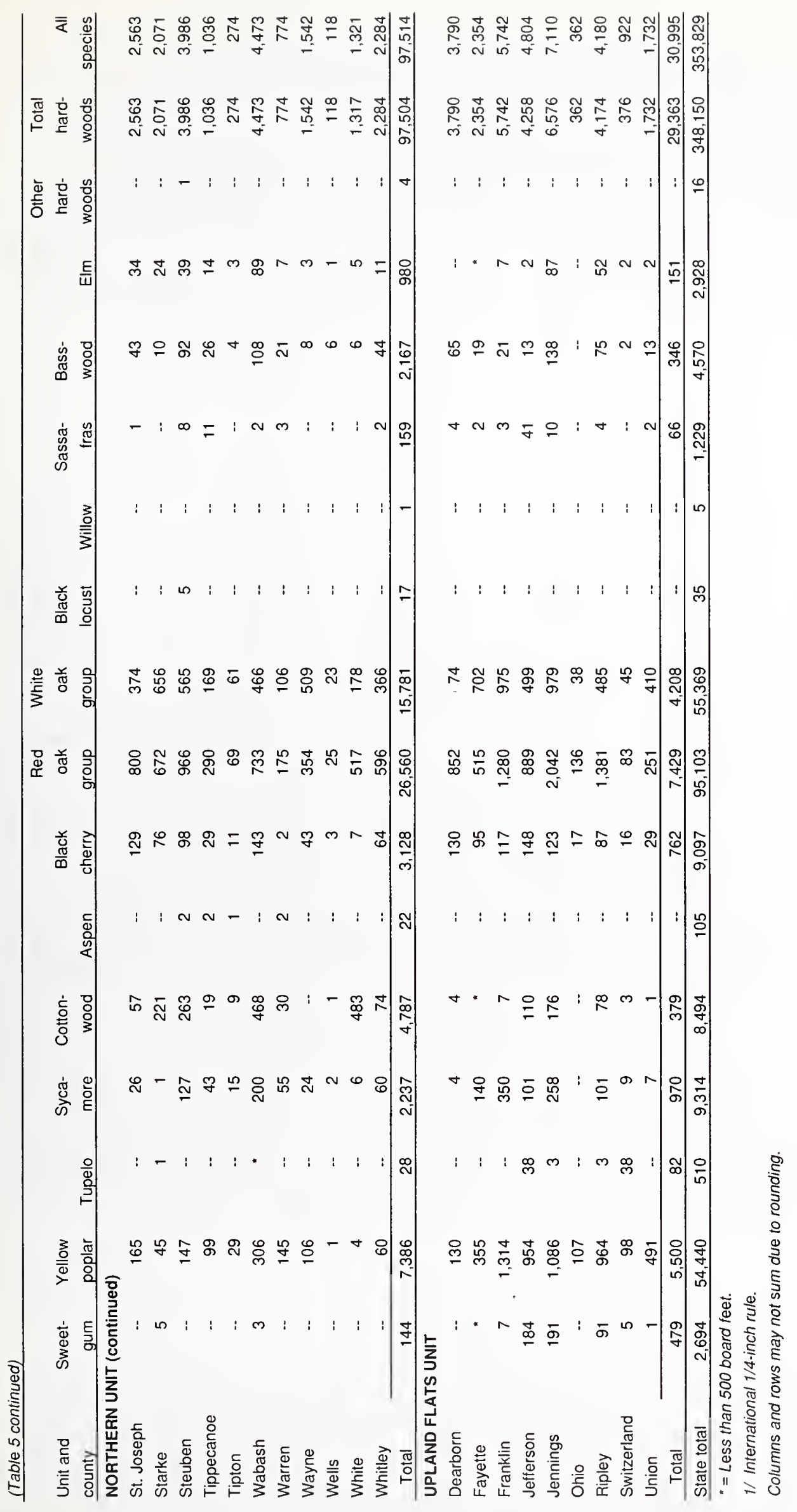


Table 6.--Saw-log production by Forest Survey Unit, species group, and State of destination, Indiana, 1995

(In thousand board feet) 1/

\section{ALL UNITS}

\begin{tabular}{|c|c|c|c|c|c|c|}
\hline Species & Total & Indiana & Michigan & Kentucky & Ohio & $\begin{array}{l}\text { Other } \\
\text { States }\end{array}$ \\
\hline \multicolumn{7}{|l|}{ HARDWOODS } \\
\hline Soft maple & 16,313 & 16,070 & 149 & 10 & 84 & -- \\
\hline Hard maple & 21,912 & 21,515 & 111 & 75 & 211 & -- \\
\hline River birch & 70 & 10 & -- & 60 & -- & -- \\
\hline Yellow birch & 11 & -- & -- & 11 & -- & - \\
\hline Hickory & 18,375 & 18,298 & 11 & 10 & 56 & -. \\
\hline Pecan & 107 & 107 & .. & -- & -- & -- \\
\hline Hackberry & 1,187 & 1,187 & -- & -- & -- & -- \\
\hline Persimmon & 15 & 15 & -- & * & -- & .. \\
\hline Beech & 8,843 & 8,735 & 2 & 75 & 31 & -- \\
\hline Ash & 27,934 & 27,272 & 84 & 20 & 557 & -. \\
\hline Honeylocust & * & * & -- & -- & -- & -- \\
\hline Butternut & 1 & 1 & .. & -- & -- & -- \\
\hline Black walnut & 9,473 & 8,212 & 25 & 21 & 1,215 & -- \\
\hline Sweetgum & 2,694 & 2,694 & -- & -- & -- & -- \\
\hline Yellow-poplar & 54,440 & 53,760 & 18 & 567 & 96 & -- \\
\hline Tupelo & 510 & 156 & -- & 354 & -- & -. \\
\hline Sycamore & 9,314 & 9,149 & - & 80 & 85 & -. \\
\hline Cottonwood & 8,494 & 8,404 & -- & 80 & 10 & -- \\
\hline Aspen & 105 & 105 & - & -- & -- & -- \\
\hline Black cherry & 9,097 & 9,046 & 36 & -- & 15 & -- \\
\hline Red oak group & 95,103 & 92,099 & 729 & 822 & 1,454 & -- \\
\hline White oak group & 55,369 & 53,523 & 276 & 561 & 1,009 & -- \\
\hline Black locust & 35 & 35 & -- & -- & -- & -- \\
\hline Willow & 5 & 5 & -- & -- & -. & -- \\
\hline Sassafras & 1,229 & 1,229 & -- & -- & -- & - \\
\hline Basswood & 4,570 & 4,360 & 20 & 71 & 119 & -- \\
\hline Elm & 2,928 & 2,840 &.- & 71 & 17 & -- \\
\hline Other hardwoods & 16 & 16 & -- & $\cdots$ & -- & - \\
\hline Total & 348,150 & 338,844 & 1,459 & 2,888 & 4,959 & .. \\
\hline \multicolumn{7}{|l|}{ SOFTWOODS } \\
\hline Redcedar & 681 & 681 & -- & -- & -. & -- \\
\hline Shortleaf pine & 1,633 & 69 & -- & -- & -- & 1,564 \\
\hline Red pine & 125 & 125 & -- & -- & -- & -- \\
\hline White pine & 111 & 111 & -- & -- & -- & -- \\
\hline Other pine & 3,128 & -. & -- & -- & -- & 3,128 \\
\hline$\frac{\text { Total }}{\text { All species }}$ & $\begin{array}{r}5,678 \\
353,829\end{array}$ & $\begin{array}{r}986 \\
339,830\end{array}$ & $\begin{array}{r}-- \\
1,459\end{array}$ & $\begin{array}{r}-- \\
2,888\end{array}$ & $\begin{array}{r}-- \\
4,959\end{array}$ & $\frac{4,692}{4,692}$ \\
\hline
\end{tabular}


(Table 6 continued)

\section{KNOBS UNIT}

\begin{tabular}{|c|c|c|c|c|c|c|}
\hline Species & Total & Indiana & Michigan & Kentucky & Ohio & $\begin{array}{l}\text { Other } \\
\text { States }\end{array}$ \\
\hline \multicolumn{7}{|l|}{ HARDWOODS } \\
\hline Soft maple & 4,197 & 4,191 & -- & 5 & -- & -- \\
\hline Hard maple & 8,879 & 8,824 & -- & 55 & -- & -- \\
\hline Yellow birch & 6 & -- & -- & 6 & -- & -- \\
\hline Hickory & 7,142 & 7,136 & -- & 6 & -- & -- \\
\hline Pecan & 81 & 81 & -- & -- & -- & -- \\
\hline Hackberry & 342 & 342 & -- & -- & -- & -- \\
\hline Persimmon & 7 & 7 & -- & * & -- & -- \\
\hline Beech & 3,221 & 3,184 & -- & 37 & -- & -. \\
\hline Ash & 8,075 & 8,069 & -- & 6 & -- & -- \\
\hline Black walnut & 2,037 & 2,029 & -- & 8 & -- & -- \\
\hline Sweetgum & 1,580 & 1,580 & -- & - & -- & -- \\
\hline Yellow-poplar & 25,884 & 25,619 & -- & 265 & -- & -- \\
\hline Tupelo & 244 & 67 & -- & 177 & -- & -- \\
\hline Sycamore & 2,622 & 2,607 & $-\cdot$ & 15 & -- & -- \\
\hline Cottonwood & 1,574 & 1,535 & -. & 39 & -- & -- \\
\hline Aspen & 22 & 22 & -- & -- & -- & -- \\
\hline Black cherry & 3,008 & 3,008 & -- & -- & -- & -- \\
\hline Red oak group & 36,480 & 36,041 & -- & 439 & -- & -- \\
\hline White oak group & 20,531 & 20,208 & -- & 324 & -- & -- \\
\hline Black locust & 4 & 4 & -- & -- & -- & -- \\
\hline Willow & 2 & 2 & -- & -- & -- & -- \\
\hline Sassafras & 646 & 646 & -- & -- & -. & -. \\
\hline Basswood & 748 & 733 & -- & 15 & - & -- \\
\hline Elm & 882 & 848 & -- & 33 & -- & -- \\
\hline Other hardwoods & 5 & 5 & -- & -- & -- & -- \\
\hline Total & 128,219 & 126,788 & -- & 1,431 & -- & - \\
\hline \multicolumn{7}{|l|}{ SOFTWOODS } \\
\hline Redcedar & 644 & 644 & -- & -- & -- & -- \\
\hline Shortleaf pine & 1,089 & 46 & -- & -- & -- & 1,043 \\
\hline Red pine & 119 & 119 & -- & -- & -- & -- \\
\hline White pine & 91 & 91 & -- & -- & -- &.- \\
\hline Other pine & 2,085 & -- & -- & -- & -- & 2,085 \\
\hline Total & 4,028 & 900 & - & -- & -- & 3,128 \\
\hline All species & 132,247 & 127,688 & -- & 1,431 & -- & 3,128 \\
\hline
\end{tabular}




\begin{tabular}{|c|c|c|c|c|c|c|}
\hline Species & Total & Indiana & Michigan & Kentucky & Ohio & $\begin{array}{l}\text { Other } \\
\text { States }\end{array}$ \\
\hline \multicolumn{7}{|l|}{ HARDWOODS } \\
\hline Soft maple & 4,571 & 4,567 & -- & 5 & -- & -- \\
\hline Hard maple & 4,428 & 4,408 & -- & 20 & -. & -- \\
\hline River birch & 70 & 10 & -- & 60 & -- & -- \\
\hline Yellow birch & 6 & -- & -- & 6 & -- & -- \\
\hline Hickory & 6,337 & 6,332 & -- & 4 & -- & -- \\
\hline Pecan & 13 & 13 & -- & -- & -- & -- \\
\hline Hackberry & 501 & 501 & -- & -- & -- & -- \\
\hline Persimmon & 8 & 8 & .. & * & -- & -- \\
\hline Beech & 2,662 & 2,625 & -- & 38 & -- & -- \\
\hline Ash & 6,423 & 6,414 & -. & 8 & -- & -- \\
\hline Honeylocust & * & * & -- & -- & -- & -- \\
\hline Black walnut & 2,141 & 2,128 & -. & 13 & -- & -- \\
\hline Sweetgum & 491 & 491 & -- & -- & -- & -- \\
\hline Yellow-poplar & 15,670 & 15,368 & -- & 302 & -- & -- \\
\hline Tupelo & 157 & 45 & -. & 112 & -- & -- \\
\hline Sycamore & 3,485 & 3,426 & -- & 58 & -- & -- \\
\hline Cottonwood & 1,754 & 1,720 & -- & 34 & -- & -- \\
\hline Aspen & 61 & 61 & -- & -- & -- & -- \\
\hline Black cherry & 2,199 & 2,199 & -- & -- & -- & -- \\
\hline Red oak group & 24,634 & 24,252 & -- & 383 & -- & -- \\
\hline White oak group & 14,849 & 14,612 & -- & 237 & -- & -- \\
\hline Black locust & 14 & 14 & -- & -- & -- & -- \\
\hline Willow & 2 & 2 & -. & -- & -- & -- \\
\hline Sassafras & 358 & 358 & -- & -- & -- & -- \\
\hline Basswood & 1,309 & 1,259 & -- & 50 & -- & -- \\
\hline Elm & 915 & 882 & -- & 33 & -- & -. \\
\hline Other hardwoods & 7 & 7 & -- & -- & -- & - \\
\hline Total & 93,065 & 91,703 & -- & 1,362 & -- & - \\
\hline \multicolumn{7}{|l|}{ SOFTWOODS } \\
\hline Redcedar & 8 & 8 & -- & -- & -- & - \\
\hline Total & 8 & 8 & -- & -- & -- & -- \\
\hline All species & 93,073 & 91,710 & $\ldots$ & 1,362 & -- & -- \\
\hline
\end{tabular}




\begin{tabular}{|c|c|c|c|c|c|c|}
\hline Species & Total & Indiana & Michigan & Kentucky & Ohio & $\begin{array}{l}\text { Other } \\
\text { States }\end{array}$ \\
\hline \multicolumn{7}{|l|}{ HARDWOODS } \\
\hline Soft maple & 6,712 & 6,480 & 149 & -- & 84 & -- \\
\hline Hard maple & 7,007 & 6,716 & 111 & -- & 180 & -- \\
\hline Hickory & 3,978 & 3,924 & 11 & -- & 43 & -- \\
\hline Pecan & 14 & 14 & -- & -- & -- & -- \\
\hline Hackberry & 289 & 289 & -- & -- & -- & -- \\
\hline Beech & 2,554 & 2,524 & 2 & -- & 29 & -- \\
\hline Ash & 8,866 & 8,515 & 84 & -. & 266 & -- \\
\hline Butternut & 1 & 1 & -- & -- & -- & -- \\
\hline Black walnut & 4,683 & 3,533 & 25 & -- & 1,125 & -- \\
\hline Sweetgum & 144 & 144 & -- & -- & -- & -- \\
\hline Yellow-poplar & 7,386 & 7,334 & 18 & -- & 35 & -- \\
\hline Tupelo & 28 & 28 & -- & -- & -- & -- \\
\hline Sycamore & 2,237 & 2,186 & -- & -- & 52 & -- \\
\hline Cottonwood & 4,787 & 4,778 & -- & -- & 9 & -- \\
\hline Aspen & 22 & 22 & -- & -- & -- & -- \\
\hline Black cherry & 3,128 & 3,079 & 36 & -- & 13 & -- \\
\hline Red oak group & 26,560 & 24,841 & 729 & -- & 991 & -- \\
\hline White oak group & 15,781 & 14,848 & 276 & -. & 657 & -- \\
\hline Black locust & 17 & 17 & -- & -- & -- & -- \\
\hline Willow & 1 & 1 & -- & -- & -- & -- \\
\hline Sassafras & 159 & 159 & -- & -- & -- & -- \\
\hline Basswood & 2,167 & 2,039 & 20 & -- & 108 & -- \\
\hline Elm & 980 & 967 & -- & -- & 14 & -- \\
\hline Other hardwoods & 4 & 4 & -- & -- & -- & - \\
\hline Total & 97,504 & 92,440 & 1,459 & -- & 3,604 & - \\
\hline \multicolumn{7}{|l|}{ SOFTWOODS } \\
\hline Red pine & 6 & 6 & -- & -- & -- & -- \\
\hline White pine & 4 & 4 & -- & -- & -- & - \\
\hline Total & 10 & 10 & -- & -- & -- & - \\
\hline All species & 97,514 & 92,451 & 1,459 & -- & 3,604 & - \\
\hline
\end{tabular}


(Table 6 continued)

\begin{tabular}{|c|c|c|c|c|c|c|}
\hline \multicolumn{7}{|c|}{ UPLAND FLATS } \\
\hline Species & Total & Indiana & Michigan & Kentucky & Ohio & $\begin{array}{r}\text { Other } \\
\text { States }\end{array}$ \\
\hline \multicolumn{7}{|l|}{ HARDWOODS } \\
\hline Soft maple & 833 & 833 & -. & -- & -- & -- \\
\hline Hard maple & 1,598 & 1,567 & -- & -- & 31 & -- \\
\hline Hickory & 919 & 905 & -- & -- & 13 & -- \\
\hline Hackberry & 55 & 55 & -- & -- & -- & -- \\
\hline Beech & 405 & 403 & -. & -- & 2 & -- \\
\hline Ash & 4,570 & 4,273 & -- & 6 & 291 & -- \\
\hline Black walnut & 613 & 523 & -- & -- & 90 & -- \\
\hline Sweetgum & 479 & 479 & -- & -- & -- & -- \\
\hline Yellow-poplar & 5,500 & 5,439 & -. & -. & 61 & -- \\
\hline Tupelo & 82 & 17 & -- & 65 & -- & $\therefore$ \\
\hline Sycamore & 970 & 929 & -- & 7 & 33 & -- \\
\hline Cottonwood & 379 & 372 & -. & 7 & 1 & -. \\
\hline Black cherry & 762 & 760 & -- & -- & 2 & -- \\
\hline Red oak group & 7,429 & 6,966 & -- & -- & 463 & -- \\
\hline White oak group & 4,208 & 3,856 & -- & -- & 352 & $-\cdot$ \\
\hline Sassafras & 66 & 66 & -- & -- & -- & -- \\
\hline Basswood & 346 & 329 & -- & 6 & 11 & -- \\
\hline Elm & 151 & 143 & -- & 5 & 3 & - \\
\hline Total & 29,363 & 27,913 & - & 95 & 1,355 & - \\
\hline \multicolumn{7}{|l|}{ SOFTWOODS } \\
\hline Redcedar & 29 & 29 & -. & -- & -- & -- \\
\hline Shortleaf pine & 544 & 23 & -- & -- & -- & 521 \\
\hline White pine & 17 & 17 & -- & .. & -- & \\
\hline Other pine & 1,043 &.- & -- & -- & -- & 1,043 \\
\hline Total & 1,632 & 68 & -- & - & -- & 1,564 \\
\hline All species & 30,995 & 27,981 & - & 95 & 1,355 & 1,564 \\
\hline
\end{tabular}

${ }^{*}=$ Less than 500 board feet.

1/ International 1/4-inch rule.

Colums and rows may not sum due to rounding. 
Table 7.--Saw-log receipts by Forest Survey Unit, species group, and State of origin, Indiana, 1995

(In thousand board feet) $1 /$

ALL UNITS

\begin{tabular}{|c|c|c|c|c|c|c|c|}
\hline \multirow[b]{2}{*}{$\begin{array}{l}\text { Species } \\
\text { group }\end{array}$} & \multicolumn{7}{|c|}{ State of origin } \\
\hline & $\begin{array}{r}\text { All } \\
\text { States } \\
\end{array}$ & Indiana & Illinois & Michigan & Kentucky & Ohio & $\begin{array}{r}\text { Other } \\
\text { States }\end{array}$ \\
\hline \multicolumn{8}{|l|}{ HARDWOODS } \\
\hline Soft maple & 21,130 & 16,070 & 2,357 & 1,356 & 858 & 487 & 1 \\
\hline Hard maple & 25,693 & 21,515 & 738 & 1,328 & 1,677 & 431 & 4 \\
\hline River birch & 10 & 10 & -- & -- & -- & -- & -- \\
\hline Hickory & 21,039 & 18,298 & 1,401 & 452 & 743 & 145 & -- \\
\hline Pecan & 107 & 107 & -- & $-\cdot$ & -- & -- & -. \\
\hline Hackberry & 1,454 & 1,187 & 166 & 36 & 10 & 55 & -- \\
\hline Persimmon & 20 & 15 & -- & -- & 5 & -- & -- \\
\hline Beech & 9,804 & 8,735 & 381 & 428 & 155 & 105 & -- \\
\hline Ash & 32,752 & 27,272 & 1,472 & 1,152 & 2,005 & 828 & 22 \\
\hline Honeylocust & * & * & -- & -- & -- & -- & -- \\
\hline Butternut & 2 & 1 & -- & 1 & -- & -- & -- \\
\hline Black walnut & 10,597 & 8,212 & 789 & 538 & 764 & 272 & 23 \\
\hline Sweetgum & 3,144 & 2,694 & 162 & -- & 288 & -. & -- \\
\hline Yellow-poplar & 60,111 & 53,760 & 2,898 & 991 & 2,214 & 240 & 8 \\
\hline Tupelo & 160 & 156 & 4 & -. & -- & .- & -- \\
\hline Sycamore & 10,269 & 9,149 & 676 & 233 & 66 & 146 & 1 \\
\hline Cottonwood & 9,814 & 8,404 & 764 & 298 & 115 & 232 & -- \\
\hline Aspen & 116 & 105 & 8 & 3 & -- & -- & -- \\
\hline Black cherry & 10,828 & 9,046 & 431 & 578 & 572 & 166 & 35 \\
\hline Red oak group & 107,119 & 92,099 & 6,107 & 3,726 & 3,580 & 1,559 & 49 \\
\hline White oak group & 63,554 & 53,523 & 3,884 & 1,404 & 2,648 & 1,989 & 104 \\
\hline Black locust & 50 & 35 & 9 & 6 & -- & -- & -- \\
\hline Willow & 5 & 5 & -- & -- & -- & -- & -- \\
\hline Sassafras & 1,347 & 1,229 & 63 & 31 & 11 & 13 & -- \\
\hline Basswood & 5,158 & 4,360 & 230 & 428 & 14 & 125 & 1 \\
\hline Elm & 3,226 & 2,840 & 165 & 182 & 5 & 34 & -- \\
\hline Other hardwoods & 17 & 16 & -- & 1 & - & - & - \\
\hline Total & 397,526 & 338,844 & 22,705 & 13,170 & 15,730 & 6,828 & 249 \\
\hline \multicolumn{8}{|l|}{ SOFTWOODS } \\
\hline Redcedar & 686 & 681 & -- & -- & 5 & -- & -- \\
\hline Shortleaf pine & 69 & 69 & -- & -- & -- & -- & -- \\
\hline Red pine & 125 & 125 & -- & -- & -- & -- & - \\
\hline White pine & 111 & 111 & -- & -- &.- & .. & - \\
\hline Total & 991 & 986 & -- & - & 5 & -- & - \\
\hline All species & 398,518 & 339,830 & 22,705 & 13,170 & 15,735 & 6,828 & 249 \\
\hline
\end{tabular}

Rows and columns may not sum due to rounding. 


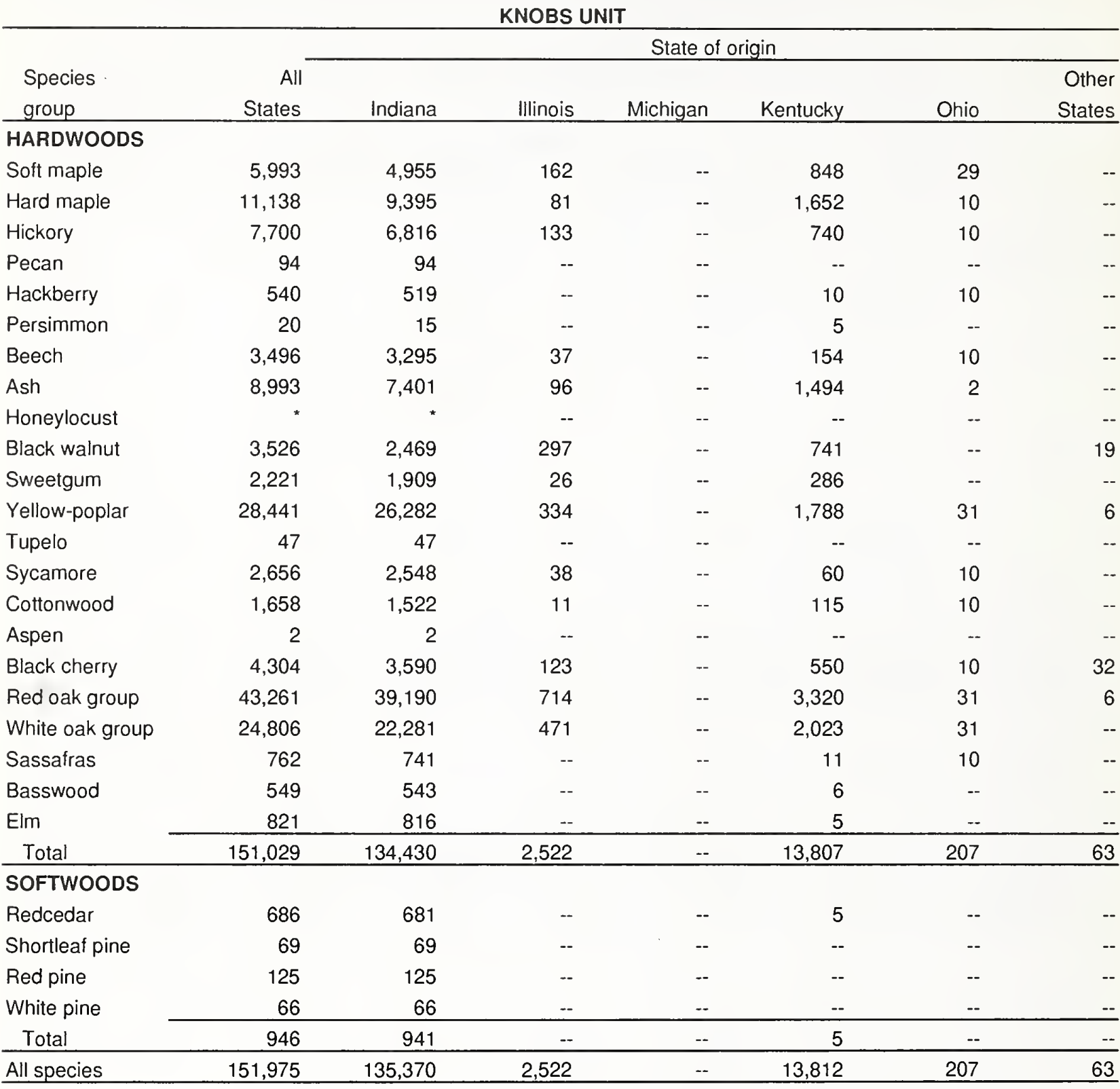

(Table 7 continued on next page) 


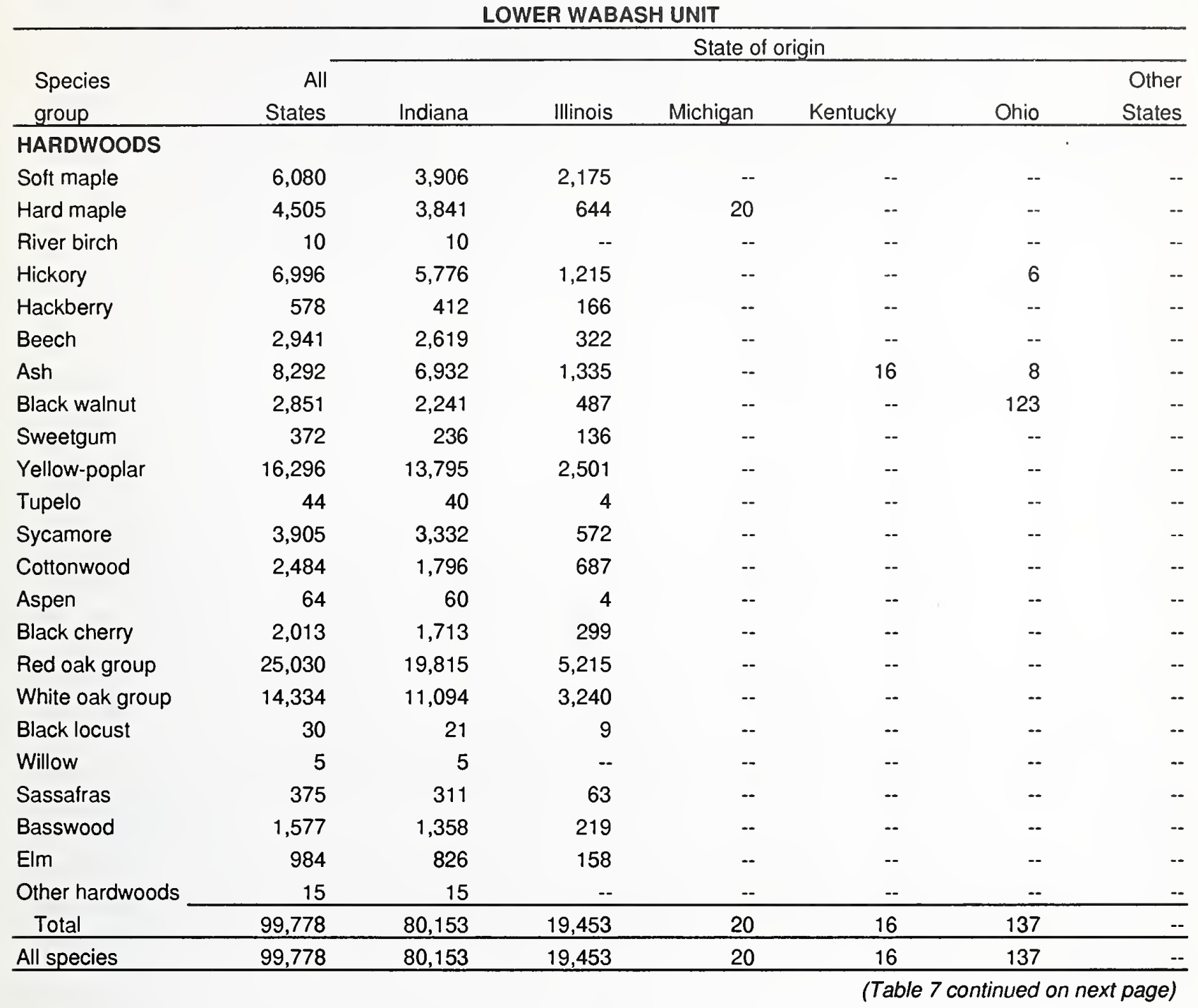




\begin{tabular}{|c|c|c|c|c|c|c|c|}
\hline \multicolumn{8}{|c|}{ NORTHERN UNIT } \\
\hline \multirow{3}{*}{$\begin{array}{l}\text { Species } \\
\text { group }\end{array}$} & \multicolumn{7}{|c|}{ State of origin } \\
\hline & All & & & & & & Other \\
\hline & States & Indiana & Illinois & Michigan & Kentucky & Ohio & States \\
\hline \multicolumn{8}{|l|}{ HARDWOODS } \\
\hline Soft maple & 8,455 & 6,610 & 20 & 1,356 & 9 & 458 & 1 \\
\hline Hard maple & 8,984 & 7,218 & 13 & 1,308 & 22 & 420 & 4 \\
\hline Hickory & 5,901 & 5,267 & 53 & 452 & -- & 129 & - \\
\hline Pecan & 14 & 14 & -- & -- & -- & -- & - \\
\hline Hackberry & 334 & 254 & -. & 36 & -- & 44 & - \\
\hline Beech & 3,149 & 2,605 & 21 & 428 & -- & 95 & - \\
\hline Ash & 12,932 & 10,754 & 41 & 1,152 & 216 & 746 & 22 \\
\hline Butternut & 2 & 1 & -- & 1 & -- & -- &.- \\
\hline Black walnut & 4,047 & 3,329 & 5 & 538 & 22 & 149 & 4 \\
\hline Sweetgum & 175 & 175 & -- & -- & -- & -- & - \\
\hline Yellow-poplar & 8,829 & 7,664 & 64 & 991 & 11 & 97 & 2 \\
\hline Tupelo & 28 & 28 & -- & -- & -- & -- &.- \\
\hline Sycamore & 2,807 & 2,368 & 66 & 233 & 4 & 135 & 1 \\
\hline Cottonwood & 5,324 & 4,738 & 66 & 298 & -- & 222 & - \\
\hline Aspen & 50 & 43 & 4 & 3 & -- & -. &.- \\
\hline Black cherry & 4,091 & 3,324 & 9 & 578 & 22 & 155 & 4 \\
\hline Red oak group & 34,327 & 28,612 & 178 & 3,726 & 256 & 1,513 & 43 \\
\hline White oak group & 22,520 & 18,256 & 174 & 1,404 & 624 & 1,958 & 104 \\
\hline Black locust & 20 & 14 & -- & 6 & -. & -. & - \\
\hline Sassafras & 209 & 175 & -- & 31 & -. & 3 & - \\
\hline Basswood & 2,767 & 2,194 & 10 & 428 & 9 & 125 & 1 \\
\hline Elm & 1,244 & 1,021 & 7 & 182 & -- & 34 & - \\
\hline Other hardwoods & 2 & 1 & -- & 1 & -. & .- &.- \\
\hline Total & 126,212 & 104,665 & 731 & 13,150 & 1,196 & 6,284 & 186 \\
\hline \multicolumn{8}{|l|}{ SOFTWOODS } \\
\hline White pine & 4 & 4 & -- & -- & -. & - & - \\
\hline Total & 4 & 4 & -- & -- & -- & -- & -- \\
\hline All species & 126,216 & 104,669 & 731 & 13,150 & 1,196 & 6,284 & 186 \\
\hline
\end{tabular}

(Table 7 continued on next page) 


\begin{tabular}{|c|c|c|c|c|c|c|c|}
\hline \multicolumn{8}{|c|}{ UPLAND FLATS UNIT } \\
\hline \multirow[b]{2}{*}{$\begin{array}{l}\text { Species } \\
\text { group }\end{array}$} & \multicolumn{7}{|c|}{ State of origin } \\
\hline & $\begin{array}{r}\text { All } \\
\text { States }\end{array}$ & Indiana & Illinois & Michigan & Kentucky & Ohio & $\begin{array}{l}\text { Other } \\
\text { States }\end{array}$ \\
\hline \multicolumn{8}{|l|}{ HARDWOODS } \\
\hline Soft maple & 601 & 599 & -- & -- & 1 & -- & -- \\
\hline Hard maple & 1,065 & 1,062 & -- & -- & 3 & 1 & -- \\
\hline Hickory & 442 & 439 & .. & -- & 3 & -- & -. \\
\hline Hackberry & 3 & 3 & -- & -- & -- & -- & -- \\
\hline Beech & 218 & 217 & -- & -- & 1 & -- & -- \\
\hline Ash & 2,535 & 2,185 & -- & -- & 279 & 72 & -- \\
\hline Black walnut & 173 & 173 & -. & -- & -- & -- & -- \\
\hline Sweetgum & 376 & 374 & -- & -- & 1 & -- & -- \\
\hline Yellow-poplar & 6,546 & 6,019 & -- & -- & 415 & 112 & -- \\
\hline Tupelo & 41 & 41 & - & -- & -- & -- & -- \\
\hline Sycamore & 902 & 900 & -- & -- & 1 & -- & .. \\
\hline Cottonwood & 348 & 348 & - & -- & -- & -- & -- \\
\hline Black cherry & 420 & 419 & -- & -- & -- & 1 & -- \\
\hline Red oak group & 4,501 & 4,482 & -- & -- & 4 & 15 & -- \\
\hline White oak group & 1,893 & 1,892 & -- & -- & 1 & -- & -- \\
\hline Sassafras & 1 & 1 & -- & - & -- & -- & -- \\
\hline Basswood & 265 & 265 & -- & -- & -- & -- & -- \\
\hline Elm & 177 & 177 & - & -- & -- & -- & - \\
\hline Total & 20,507 & 19,596 & -- & -- & 711 & 200 & - \\
\hline \multicolumn{8}{|l|}{ SOFTWOODS } \\
\hline White pine & 41 & 41 & -- & -- & -- & -- & - \\
\hline Total & 41 & 41 & -- & -- & -- & -- & - \\
\hline All species & 20,549 & 19,638 & -- & -- & 711 & 200 & - \\
\hline
\end{tabular}


Table 8.--Pulpwood production in Indiana by species group, 1966, 1976, 1984, 1990, and 1995

(In standard cords, unpeeled)

\begin{tabular}{lrrrrr}
\hline Species group & 1966 & 1976 & 1984 & 1990 & 1995 \\
\hline ROUNDwOOD & & & & & \\
Soft hardwoods & 45,365 & 17,555 & 14,912 & 11,594 & 5,375 \\
Hard hardwoods & 48,064 & 40,379 & 20,420 & 26,332 & 35,448 \\
Softwoods & 662 & -- & - &.. & 3,597 \\
$\quad$ Total & 94,091 & 57,934 & 35,332 & 37,926 & 44,419 \\
\hline & & & & & \\
RESIDUE & & & & & \\
Hardwoods & 2,349 & 114,060 & 170,568 & 151,108 & 230,698 \\
$\quad$ Softwoods & -- & -- & -- & 266 & 35,303 \\
All material & 96,440 & 171,994 & 205,900 & 189,300 & 310,421 \\
\hline
\end{tabular}


Table 9.--Roundwood pulpwood production by Forest Survey Unit and species group, Indiana, 1995

(In standard cords, unpeeled) 1/

\begin{tabular}{|c|c|c|c|c|c|}
\hline \multirow{3}{*}{$\begin{array}{l}\text { Species } \\
\text { group }\end{array}$} & \multirow{3}{*}{$\begin{array}{r}\text { All } \\
\text { Units } \\
\end{array}$} & \multicolumn{3}{|c|}{ Lower } & \multirow{2}{*}{$\begin{array}{r}\text { Upland } \\
\text { Flats }\end{array}$} \\
\hline & & Knobs & Wabash & Northern & \\
\hline & & Unit & Unit & Unit & Unit \\
\hline \multicolumn{6}{|l|}{ HARDWOODS } \\
\hline Soft maple & 1,319 & 550 & 718 & 51 & -- \\
\hline Hard maple & 1,173 & 492 & 636 & 46 & -- \\
\hline Hickory & 3,557 & 1,466 & 1,951 & 140 & -- \\
\hline Ash & 1,387 & 572 & 760 & 55 & -- \\
\hline Yellow-poplar & 4,055 & 1,672 & 2,224 & 160 & -- \\
\hline Red oak group & 11,282 & 8,689 & 2,420 & 174 & -- \\
\hline White oak group & 13,457 & 10,653 & 2,616 & 188 & .- \\
\hline Other hardwoods & 4,591 & 1,893 & 2,517 & 181 & - \\
\hline Total & 40,822 & 25,986 & 13,842 & 995 & - \\
\hline \multicolumn{6}{|l|}{ SOFTWOODS } \\
\hline Shortleaf pine & 195 & 195 & -- & -- & -- \\
\hline \multirow{2}{*}{$\begin{array}{l}\text { Other softwoods } \\
\text { Total }\end{array}$} & 3,402 & 3,402 & -- & -- & - \\
\hline & 3,597 & 3,597 & -- & -- & - \\
\hline All species & 44,419 & 29,583 & 13,842 & 995 & - \\
\hline
\end{tabular}

1/ A standard cord, unpeeled, is 128 cubic feet consisting of 79 cubic feet of wood and 49 cubic feet of bark and air space. 
Table 10.--Veneer log and bolt production in Indiana by species group, 1966, 1976, 1984, 1990, and 1995

(In thousand board feet) $1 /$

\begin{tabular}{|c|c|c|c|c|c|}
\hline Species group & 1966 & 1976 & 1984 & 1990 & 1995 \\
\hline Ash & 381 & 609 & 461 & 640 & 1,269 \\
\hline Basswood & 2 & 15 & 16 & 8 & 163 \\
\hline Black cherry & 140 & 99 & 34 & 708 & 2,076 \\
\hline Cottonwood & 1,129 & 668 & 383 & 464 & 171 \\
\hline Sweetgum & 502 & 386 & 165 & 165 & 643 \\
\hline Pecan & 732 & 354 & 231 & 298 & 252 \\
\hline Hard maple & 1,080 & 273 & 234 & 1,895 & 1,804 \\
\hline Soft maple & 36 & 266 & 314 & 200 & 752 \\
\hline Red oak group & 429 & 1,683 & 3,184 & 2,620 & 3,835 \\
\hline White oak group & 1,681 & 5,428 & 4,968 & 4,549 & 6,740 \\
\hline Sycamore & 565 & 525 & 330 & 271 & 1,543 \\
\hline Black walnut & 6,412 & 3,426 & 2,889 & 3,472 & 1,988 \\
\hline Yellow-poplar & 2,469 & 1,242 & 565 & 761 & 1,749 \\
\hline Other hardwoods & 205 & 6 & 382 & 693 & 685 \\
\hline Pine & -- & -- & 21 & 21 & -- \\
\hline All species & 17,729 & 16,956 & 14,177 & 16,765 & 23,670 \\
\hline
\end{tabular}

1/ International 1/4-inch rule. 


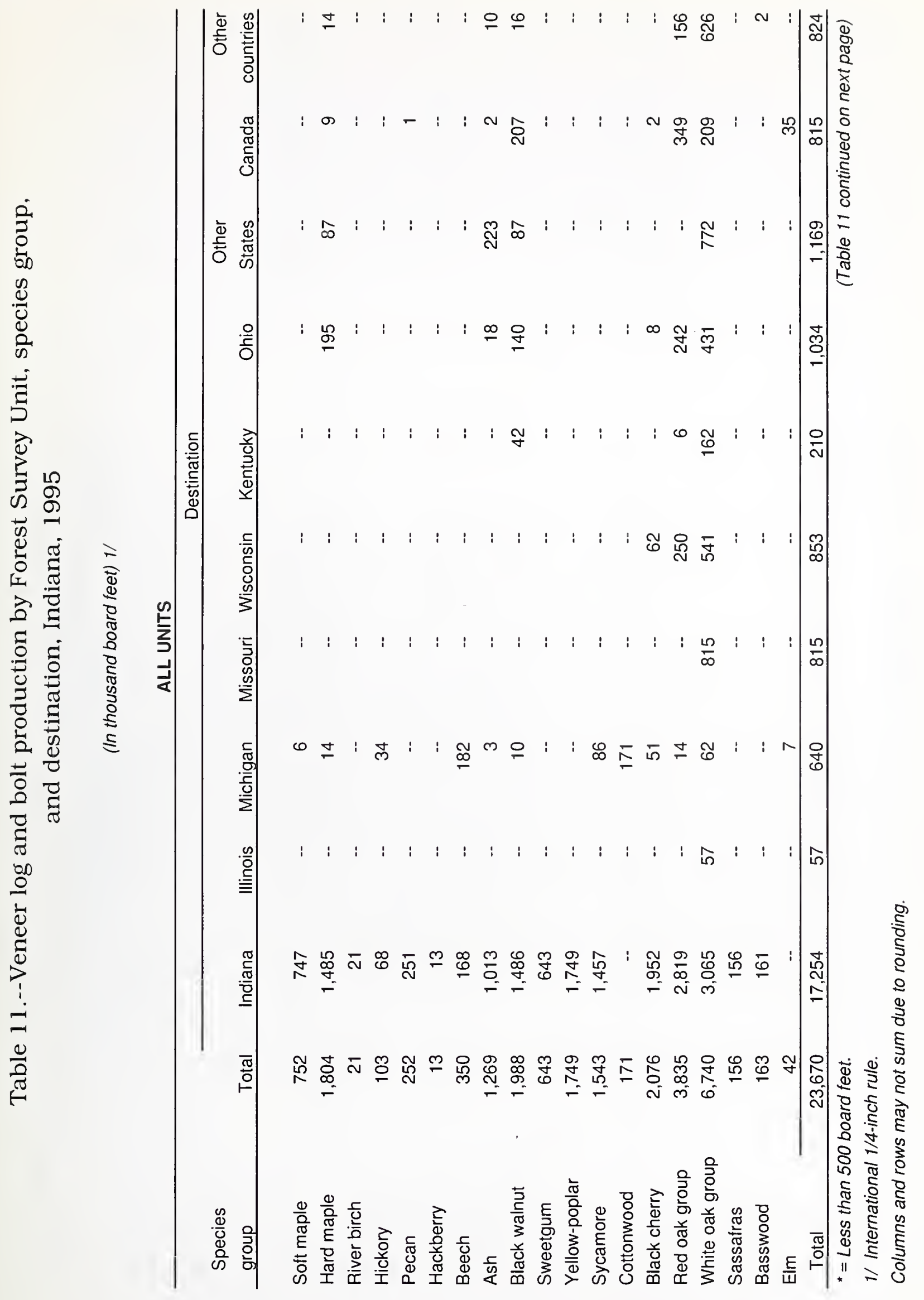




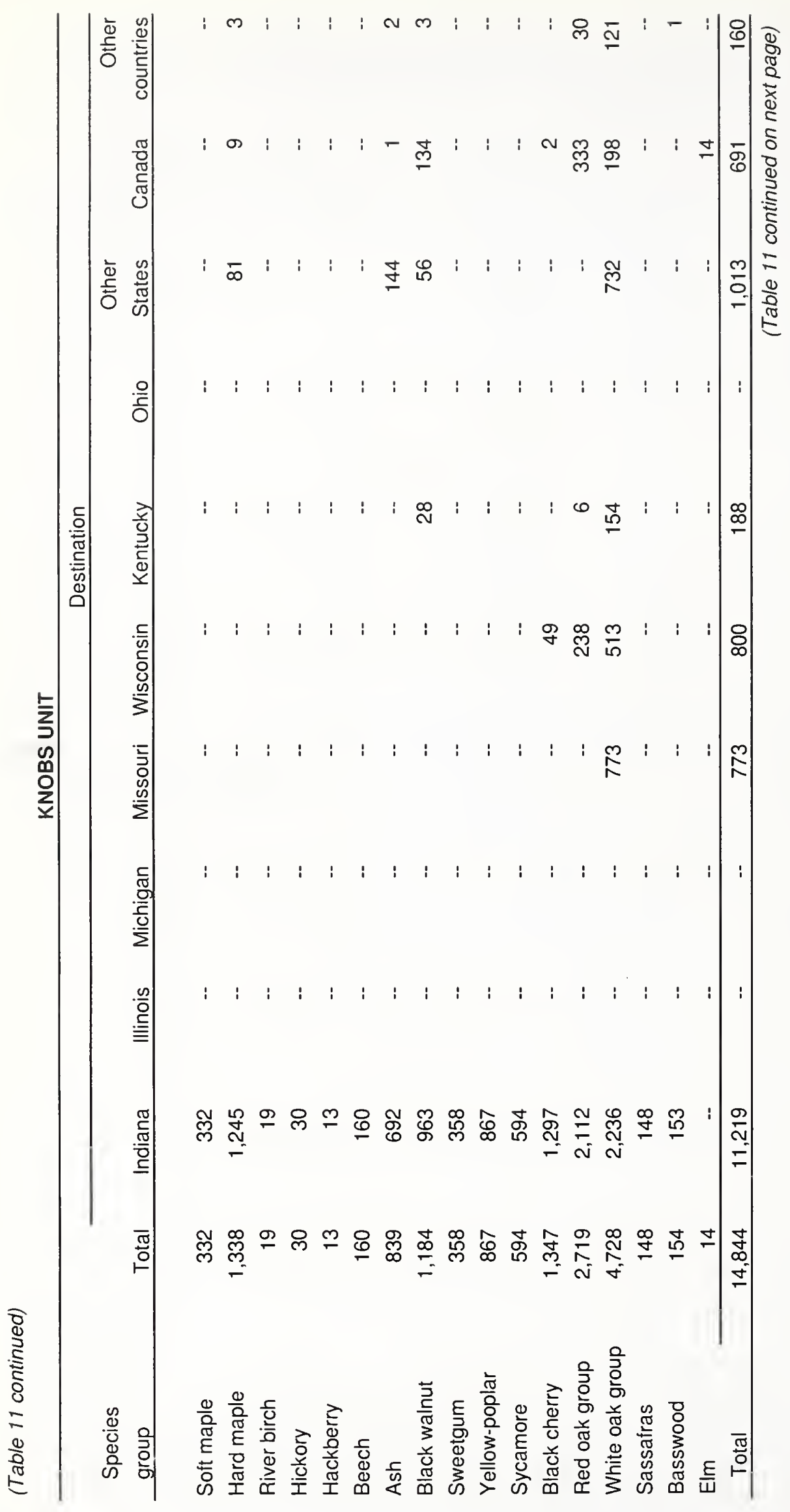




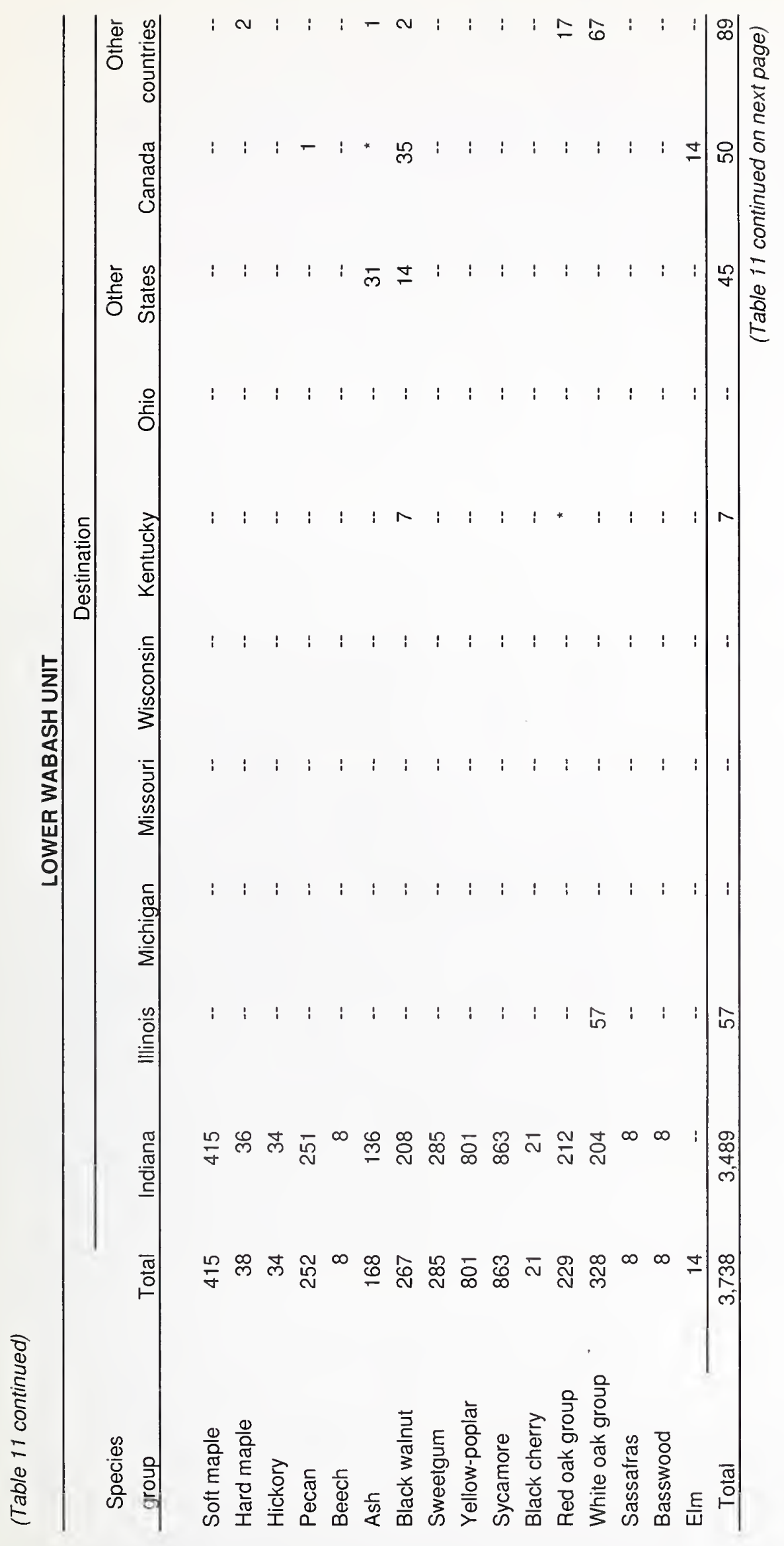




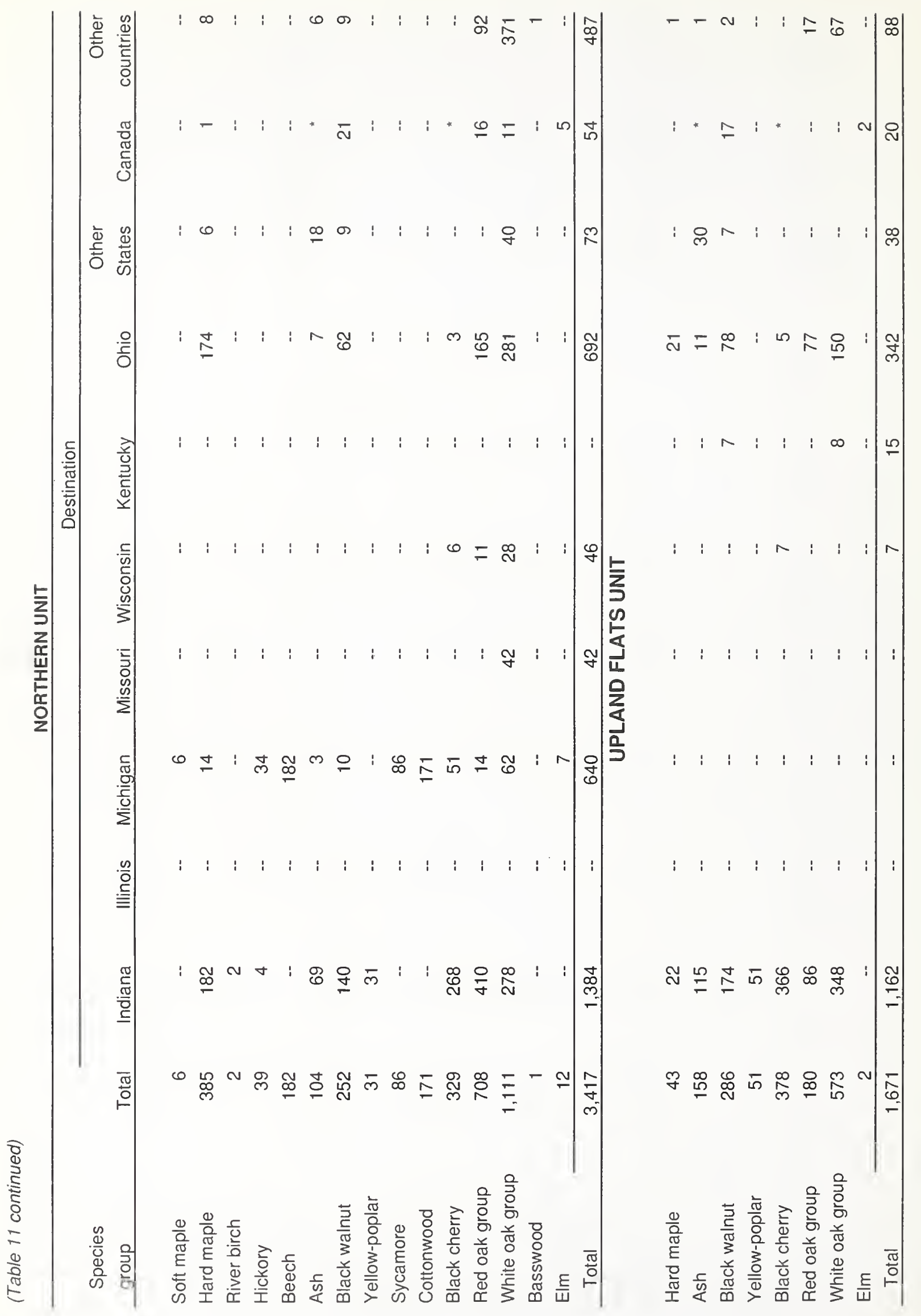




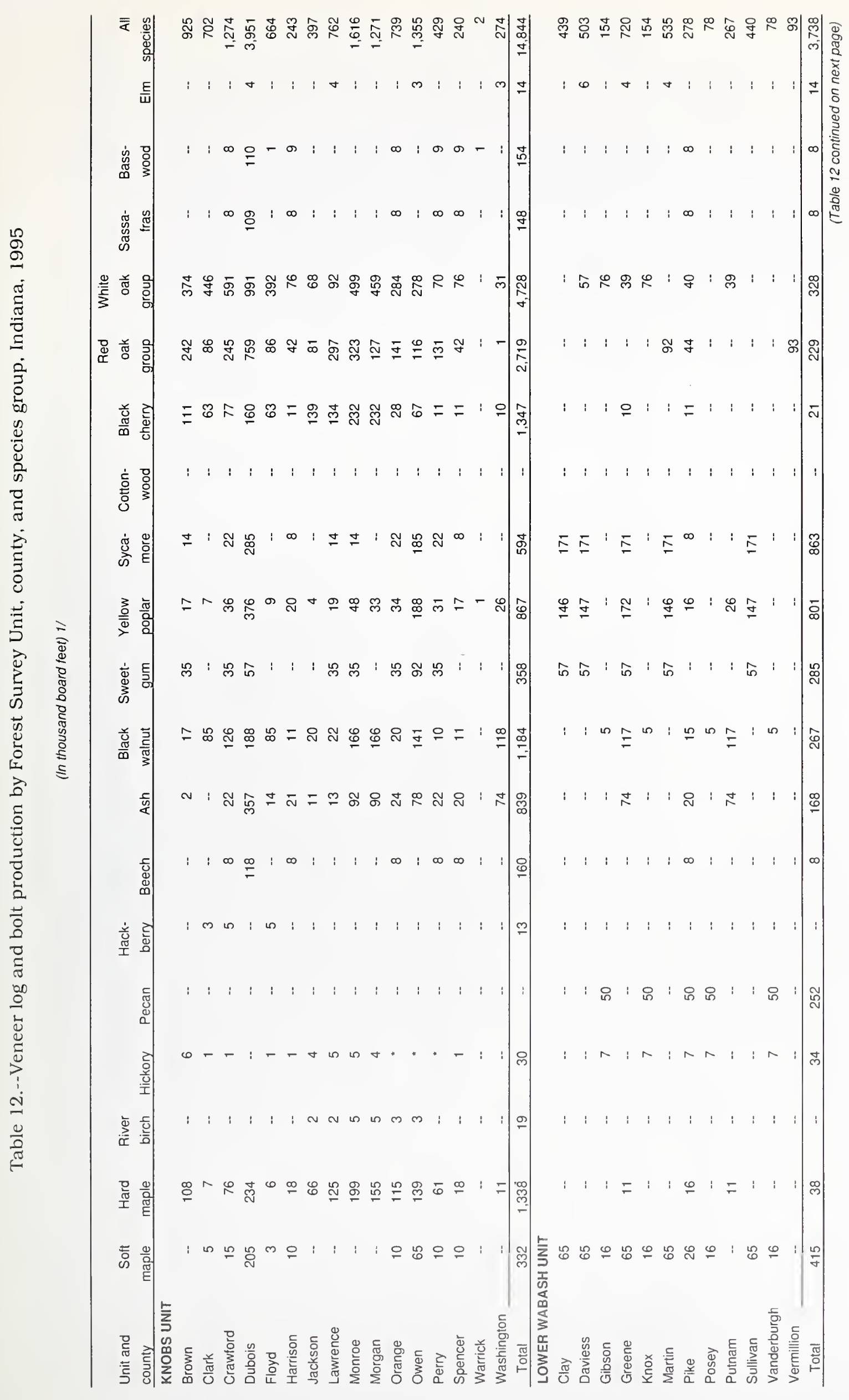




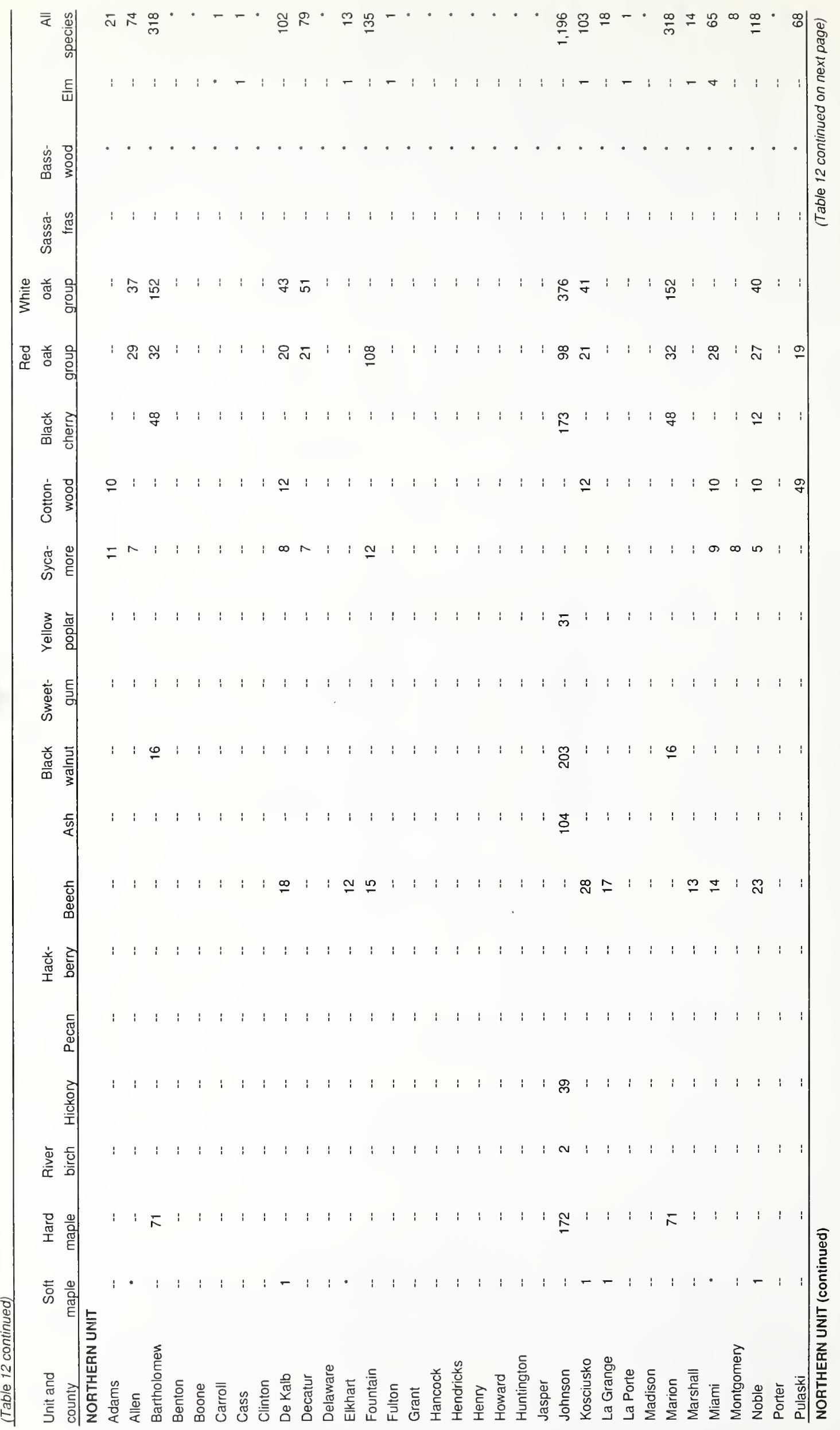




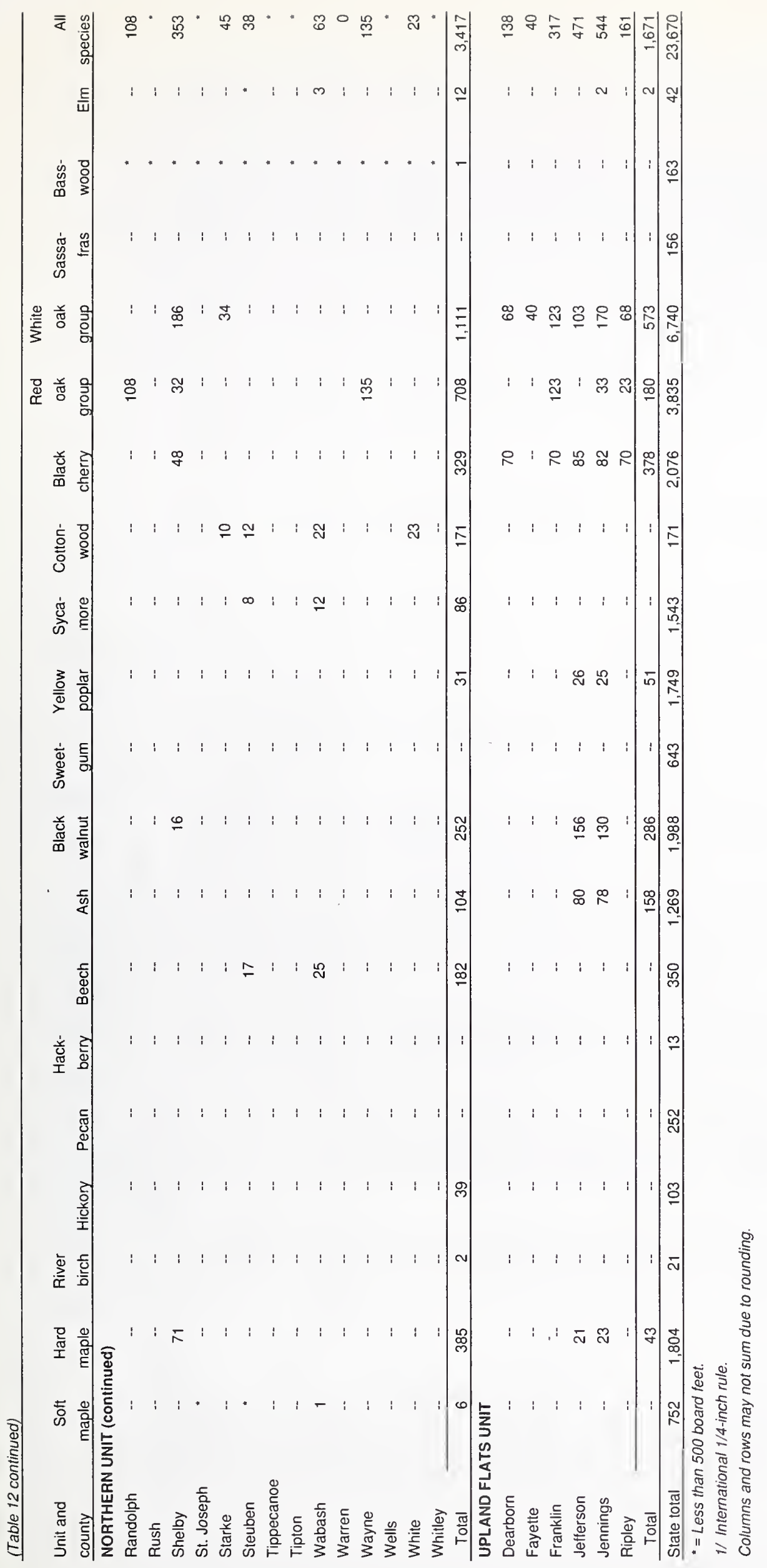




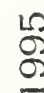

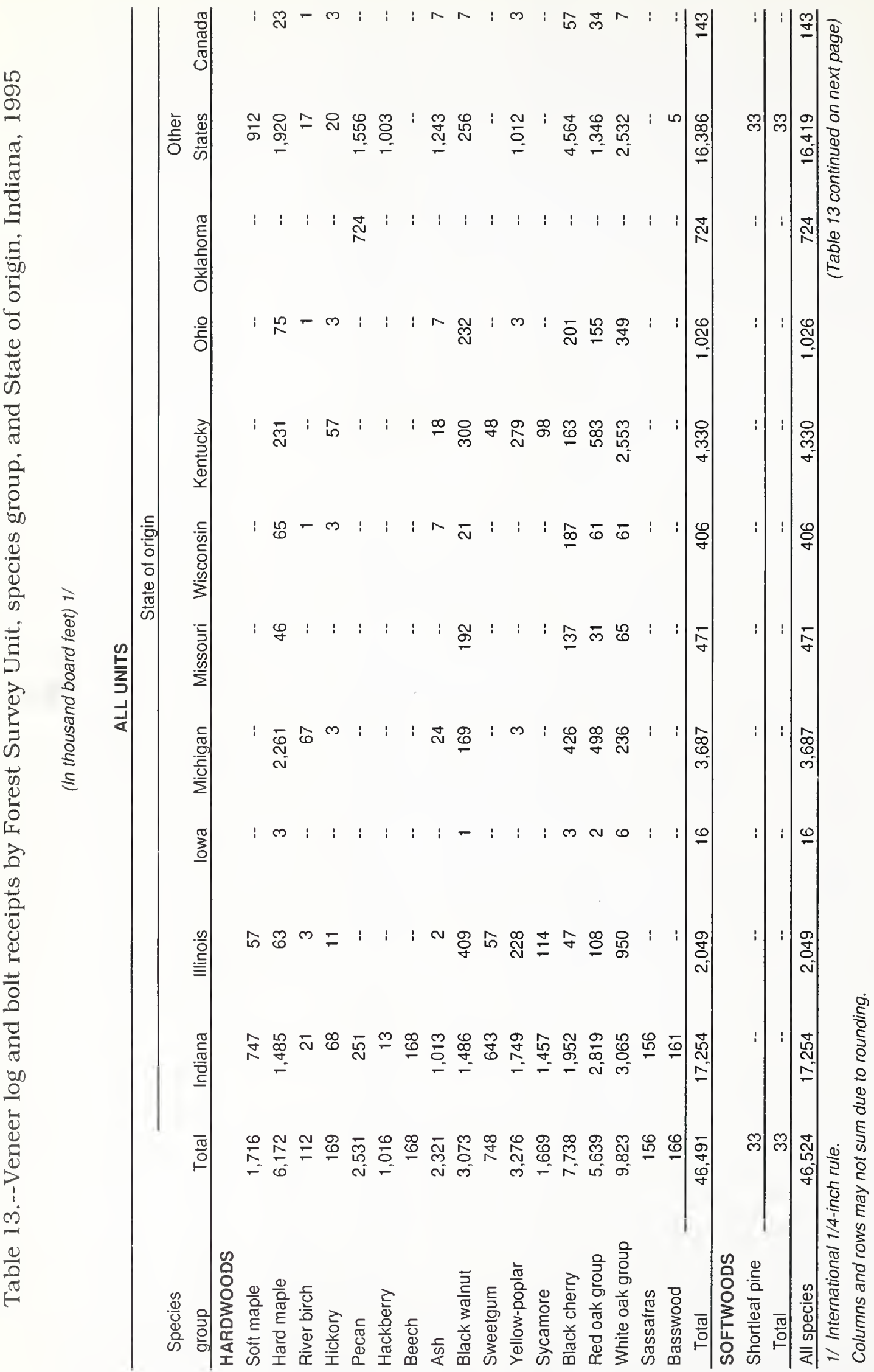




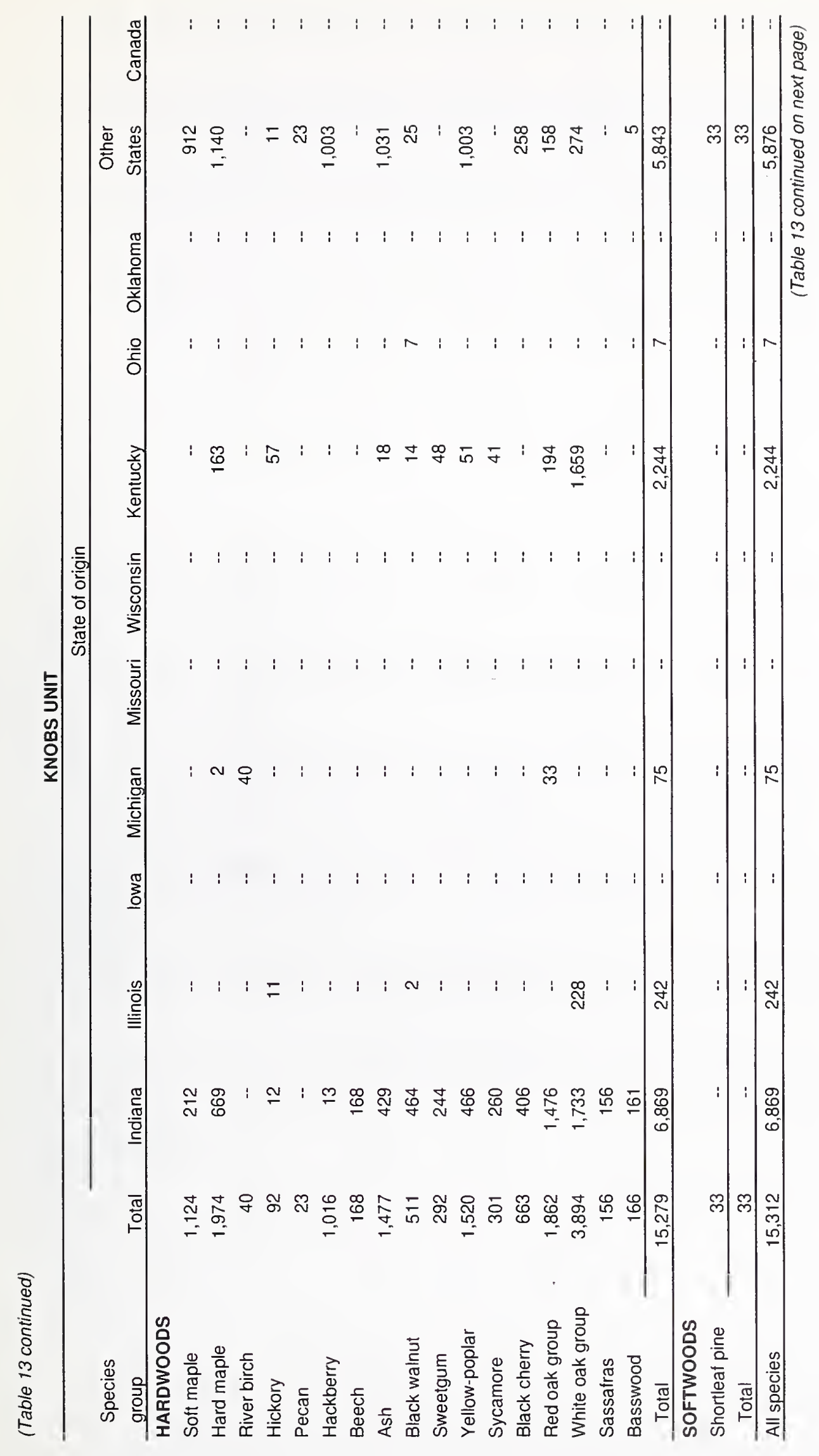




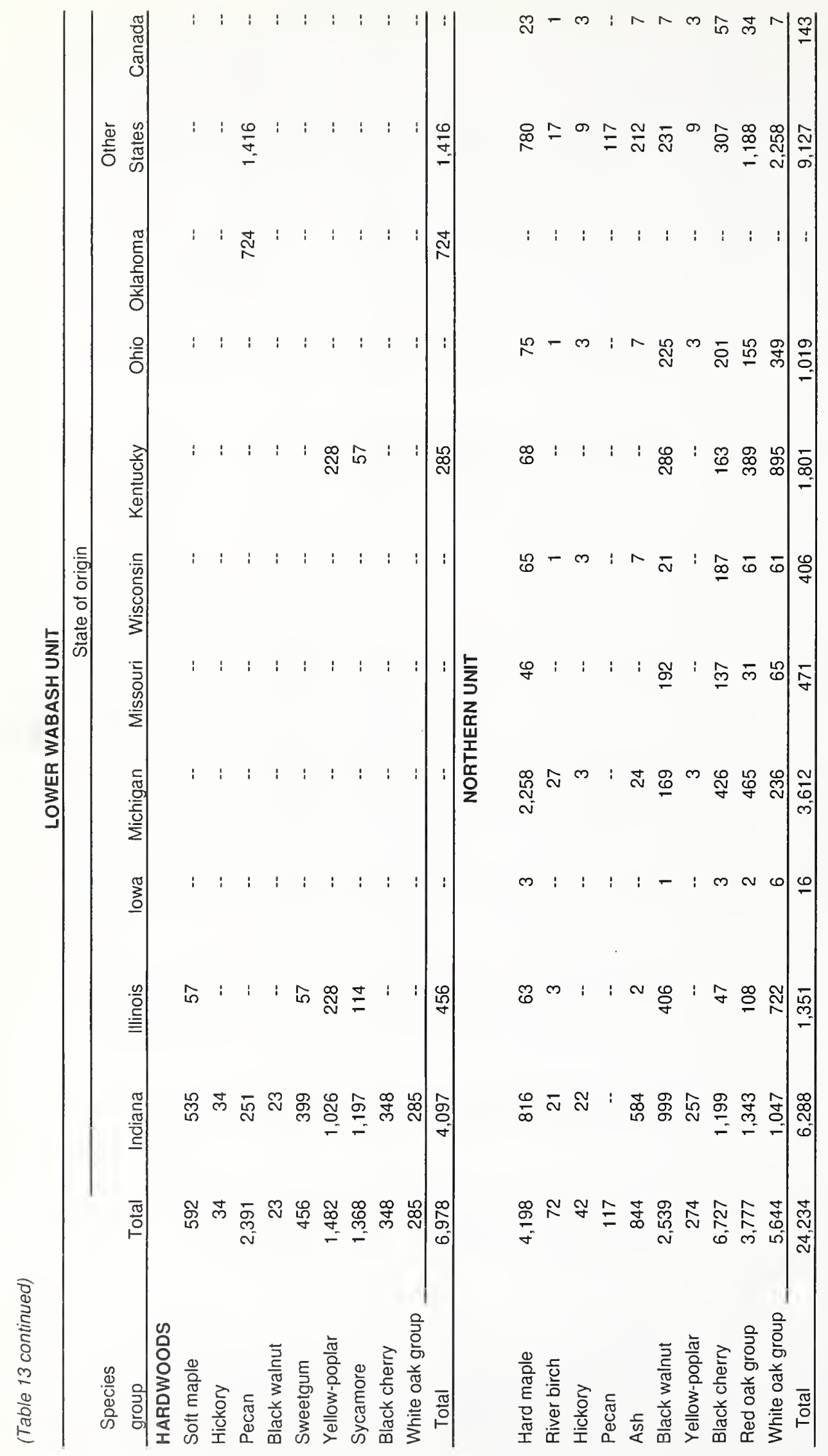




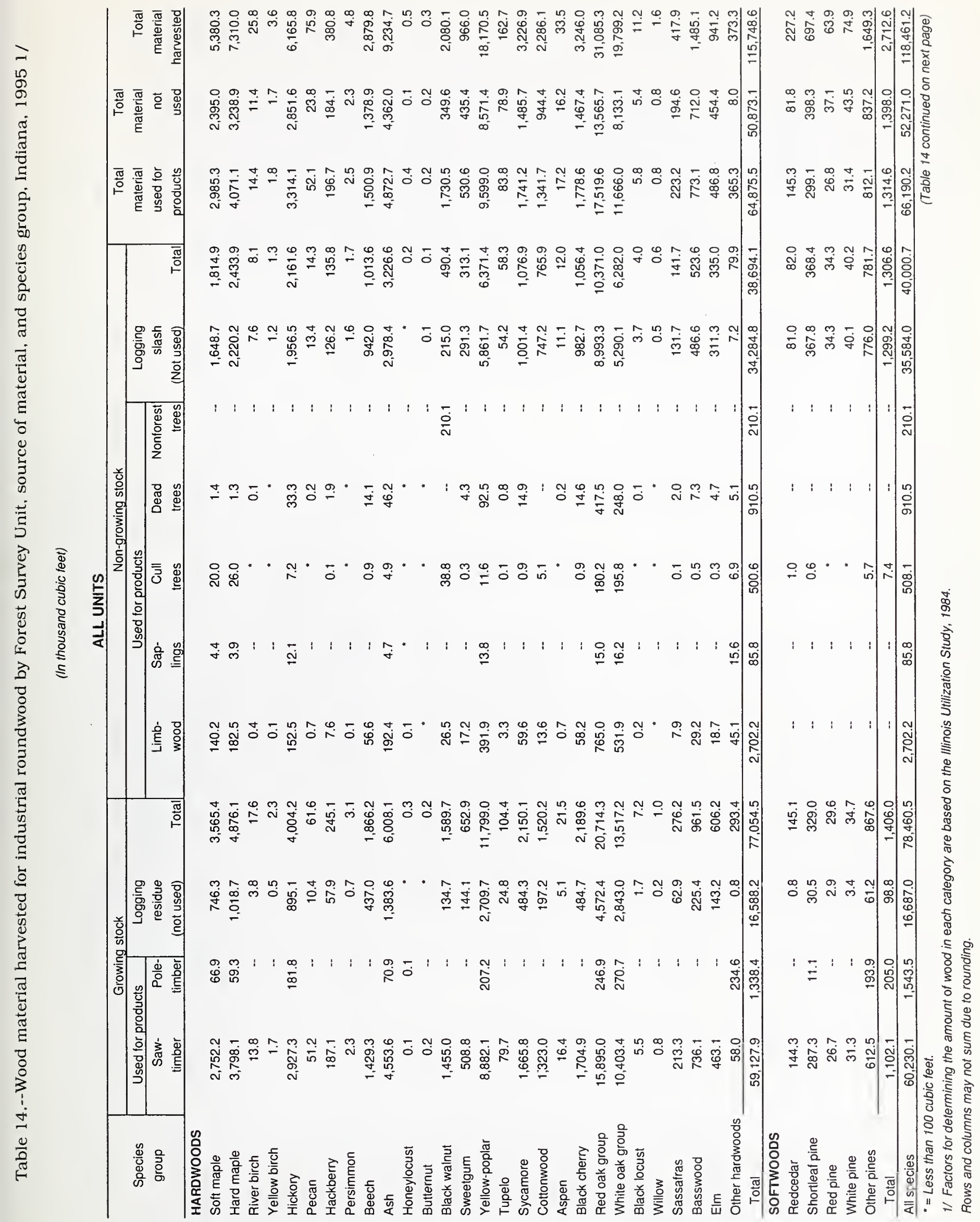




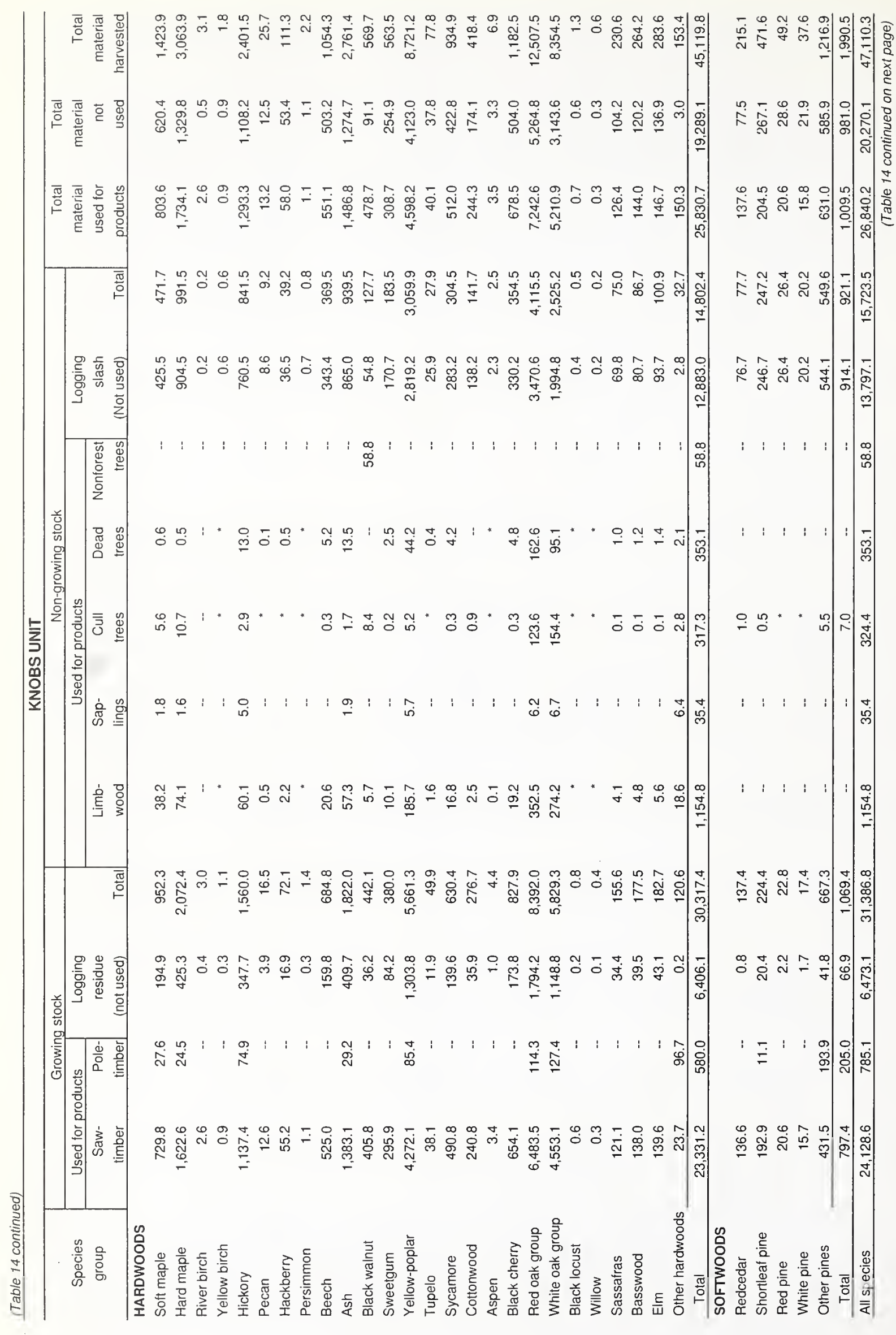




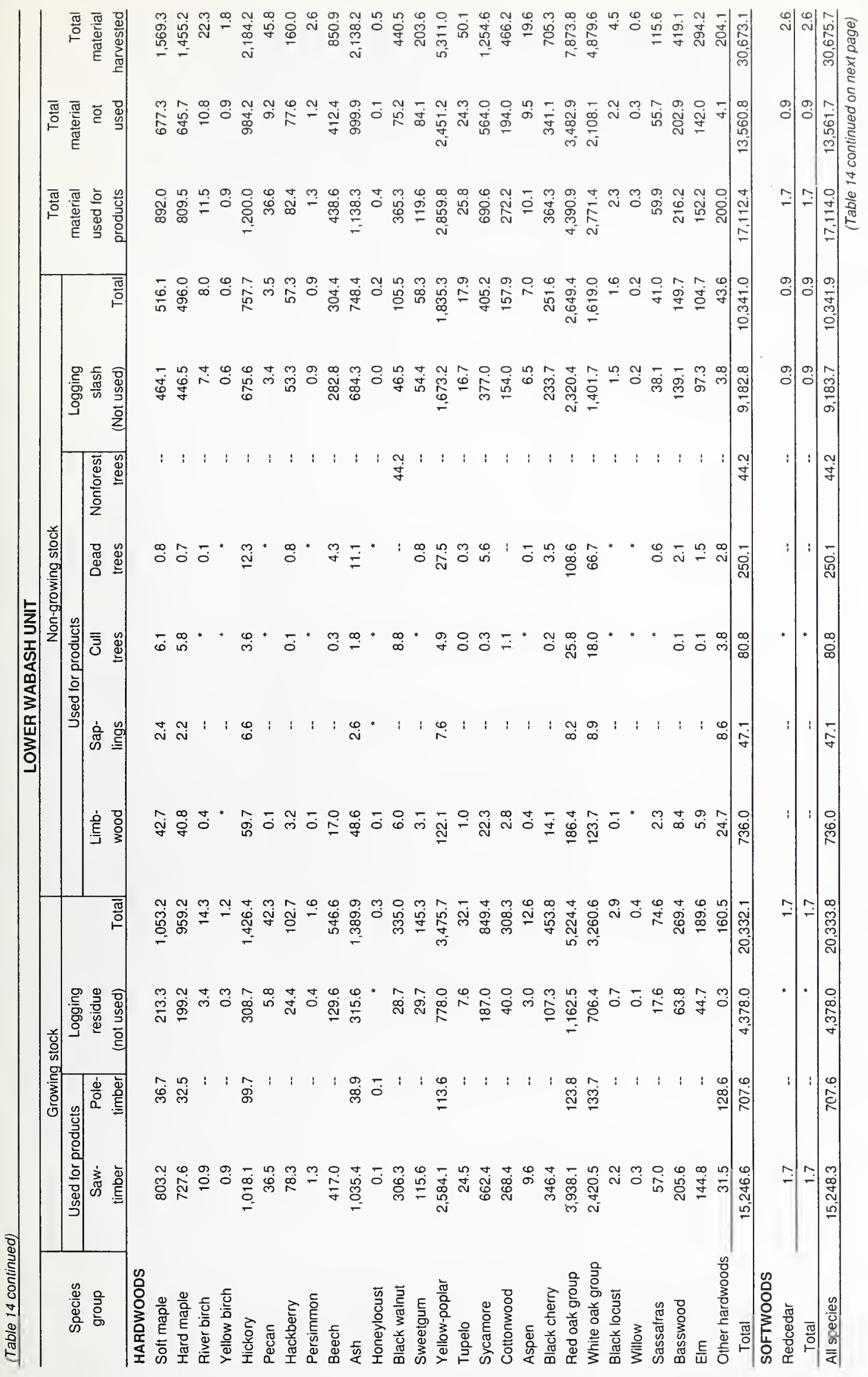




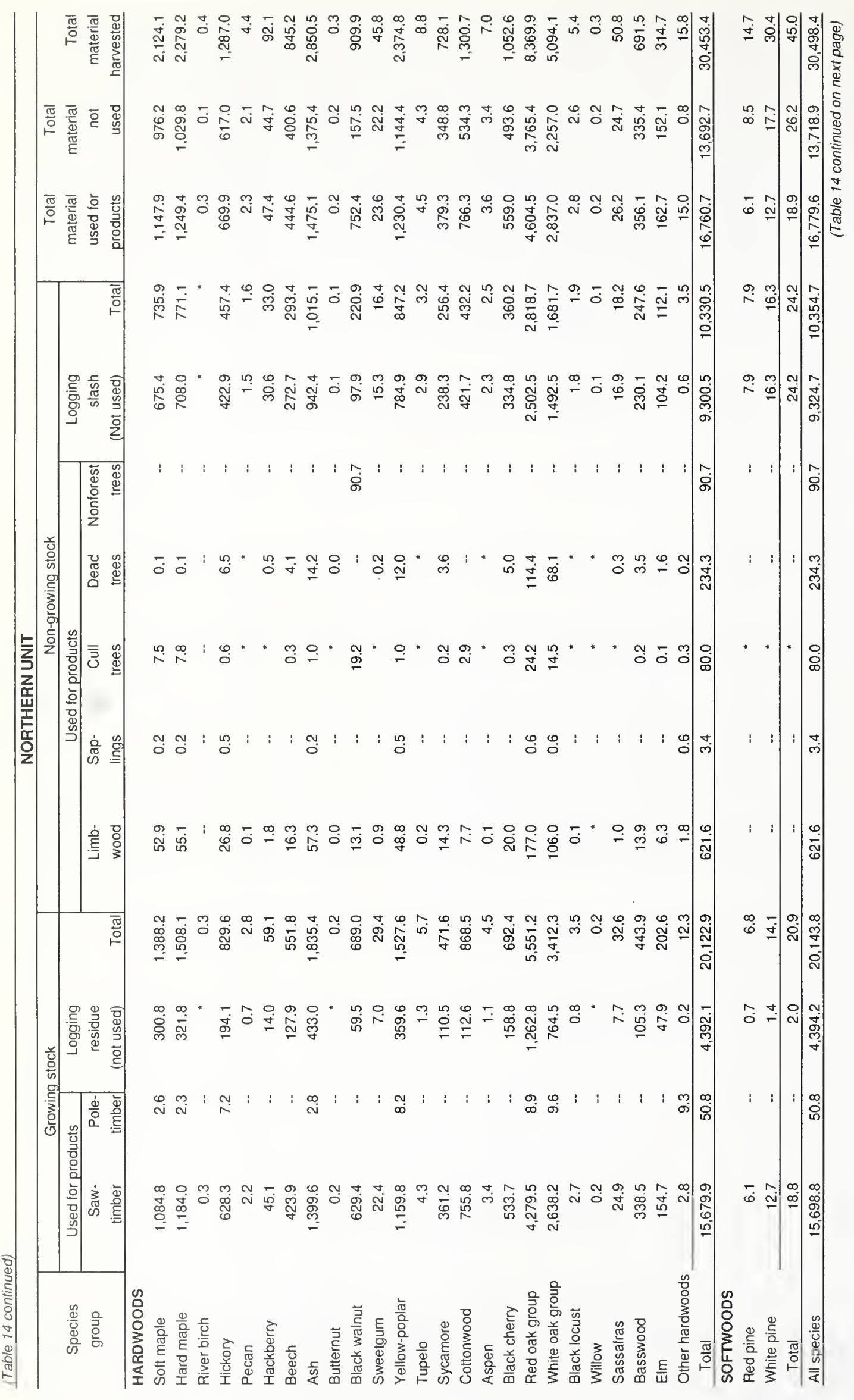




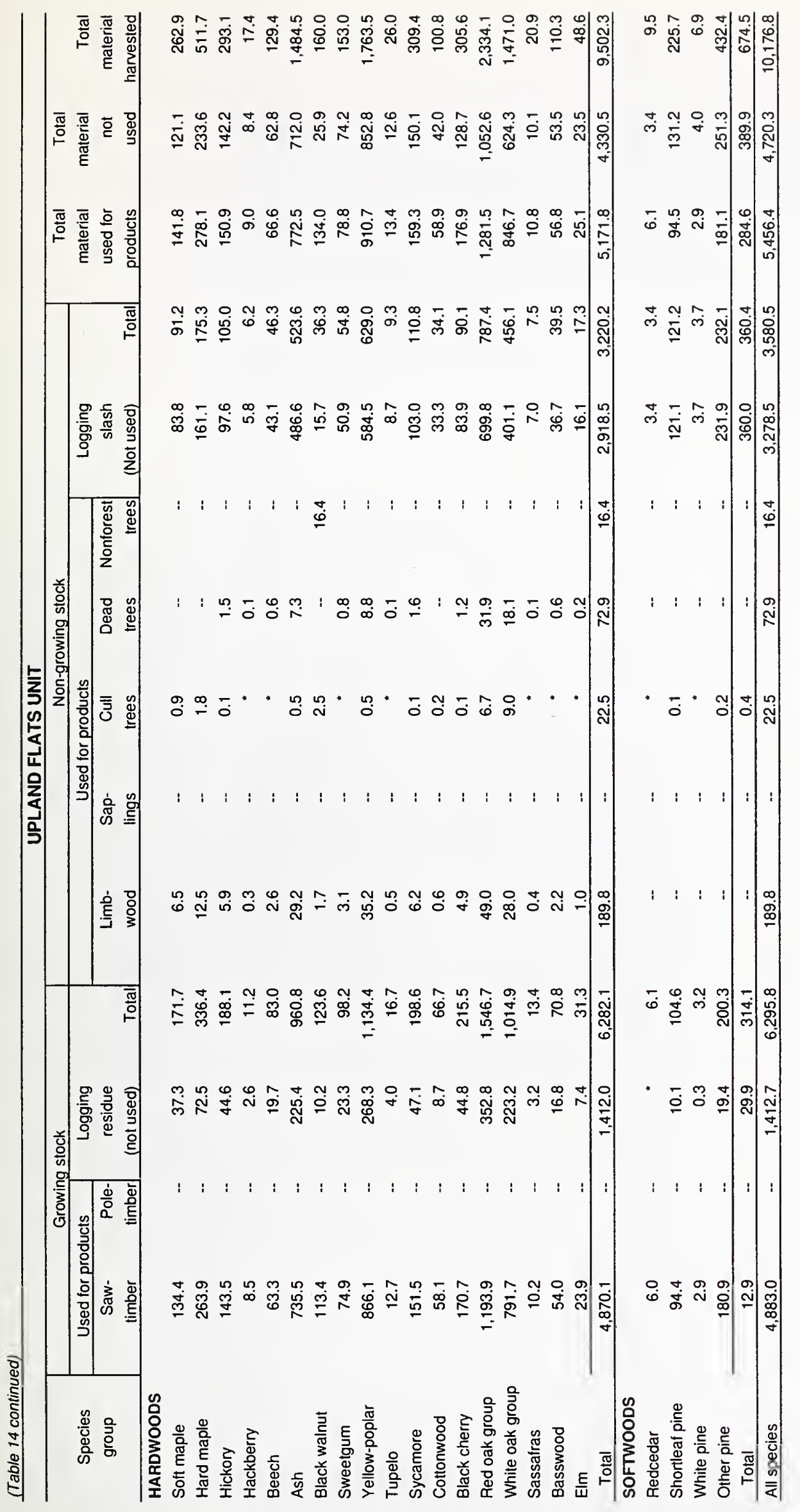




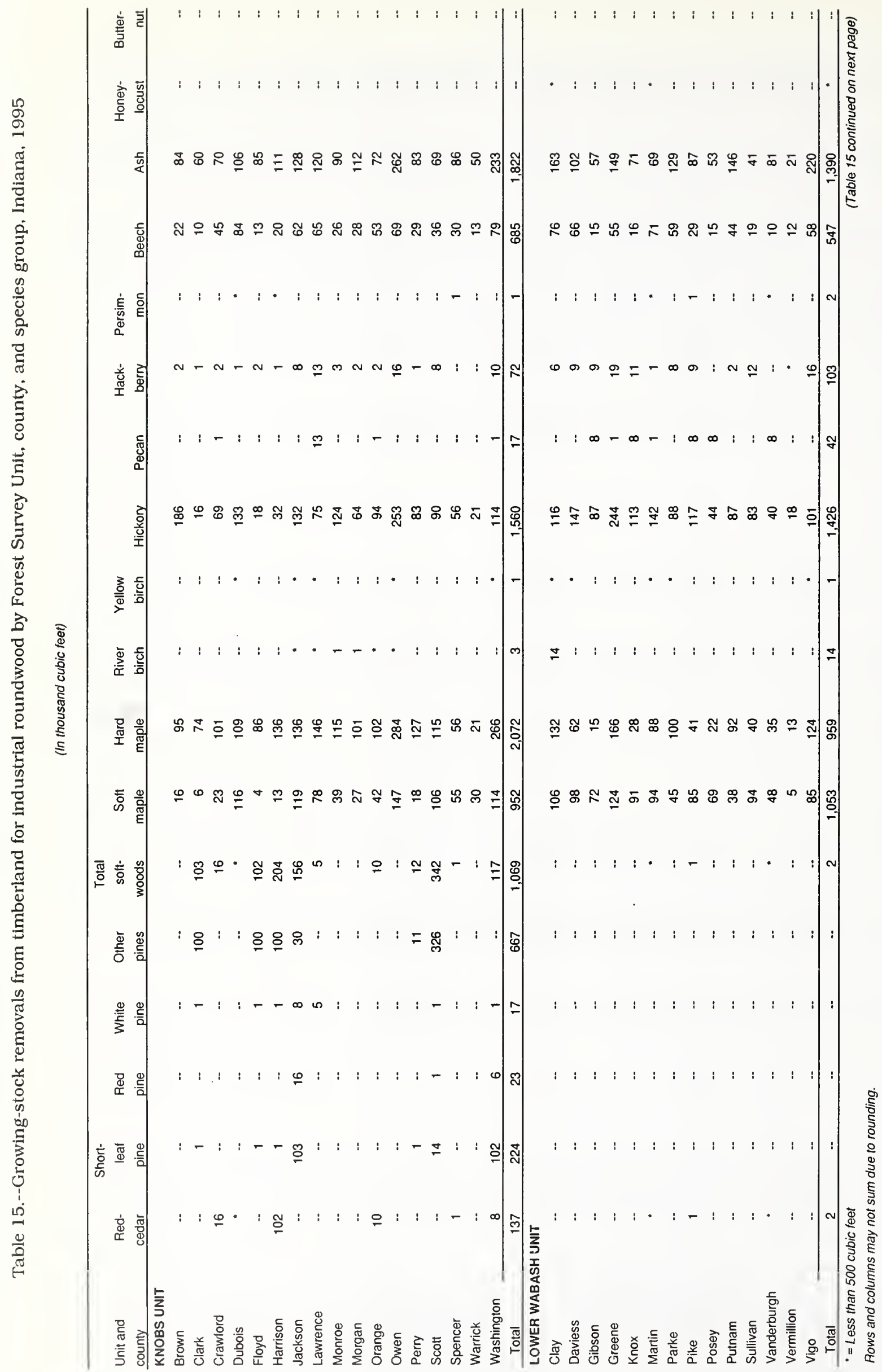




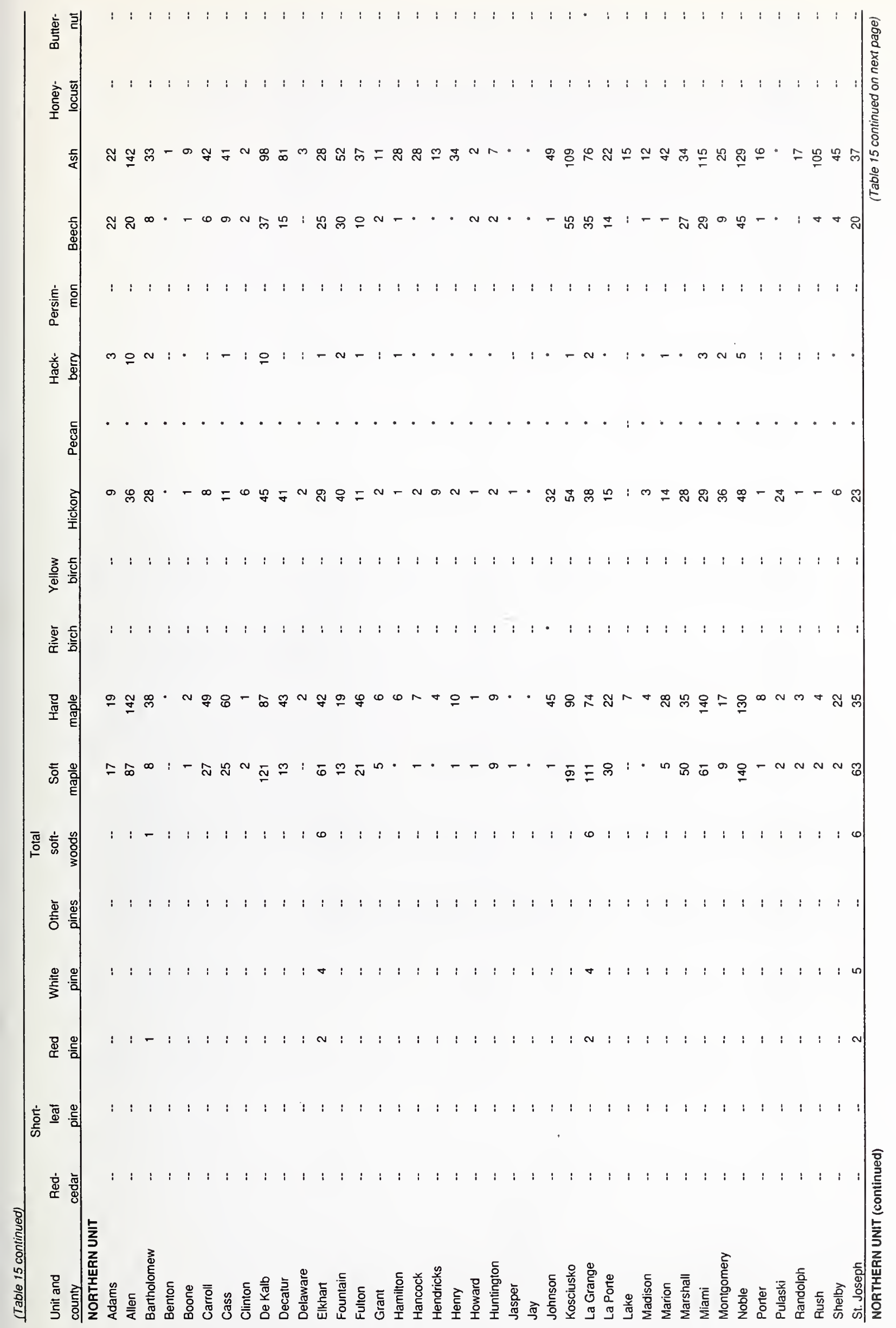




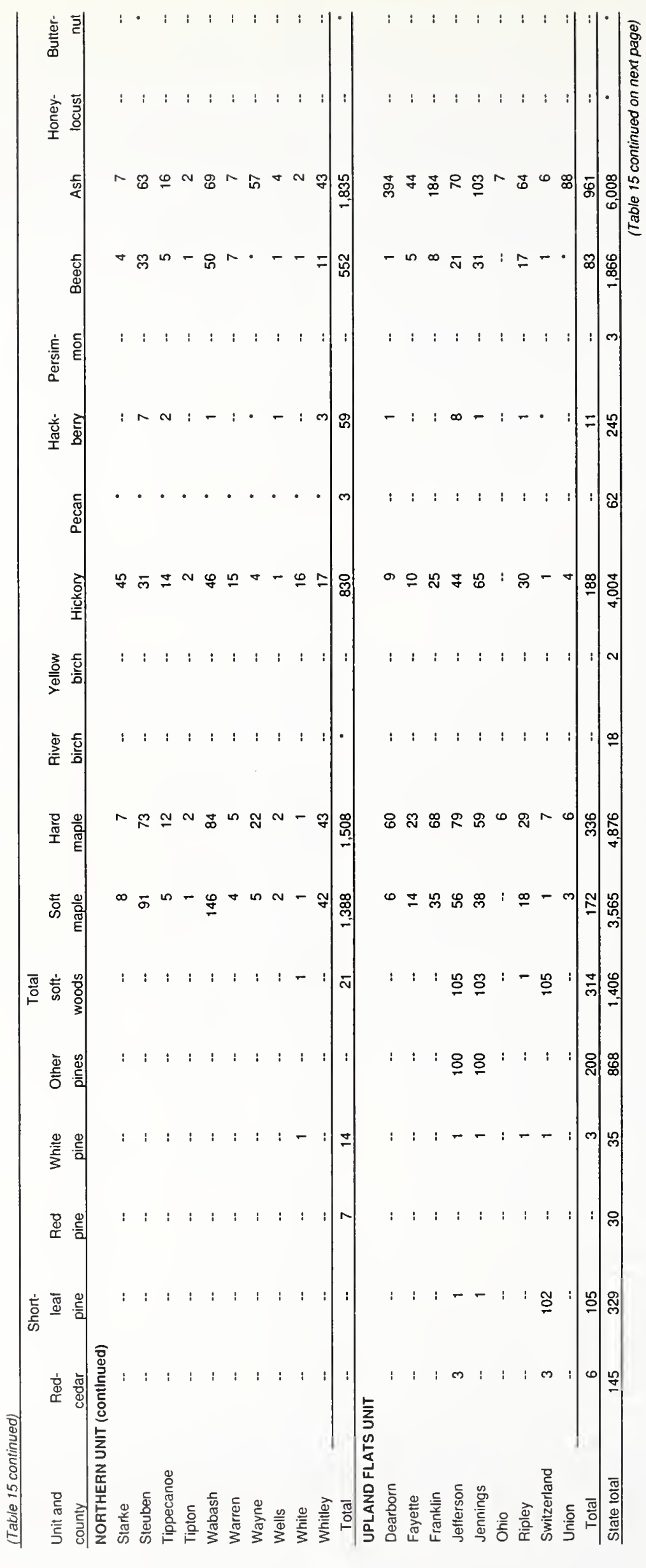




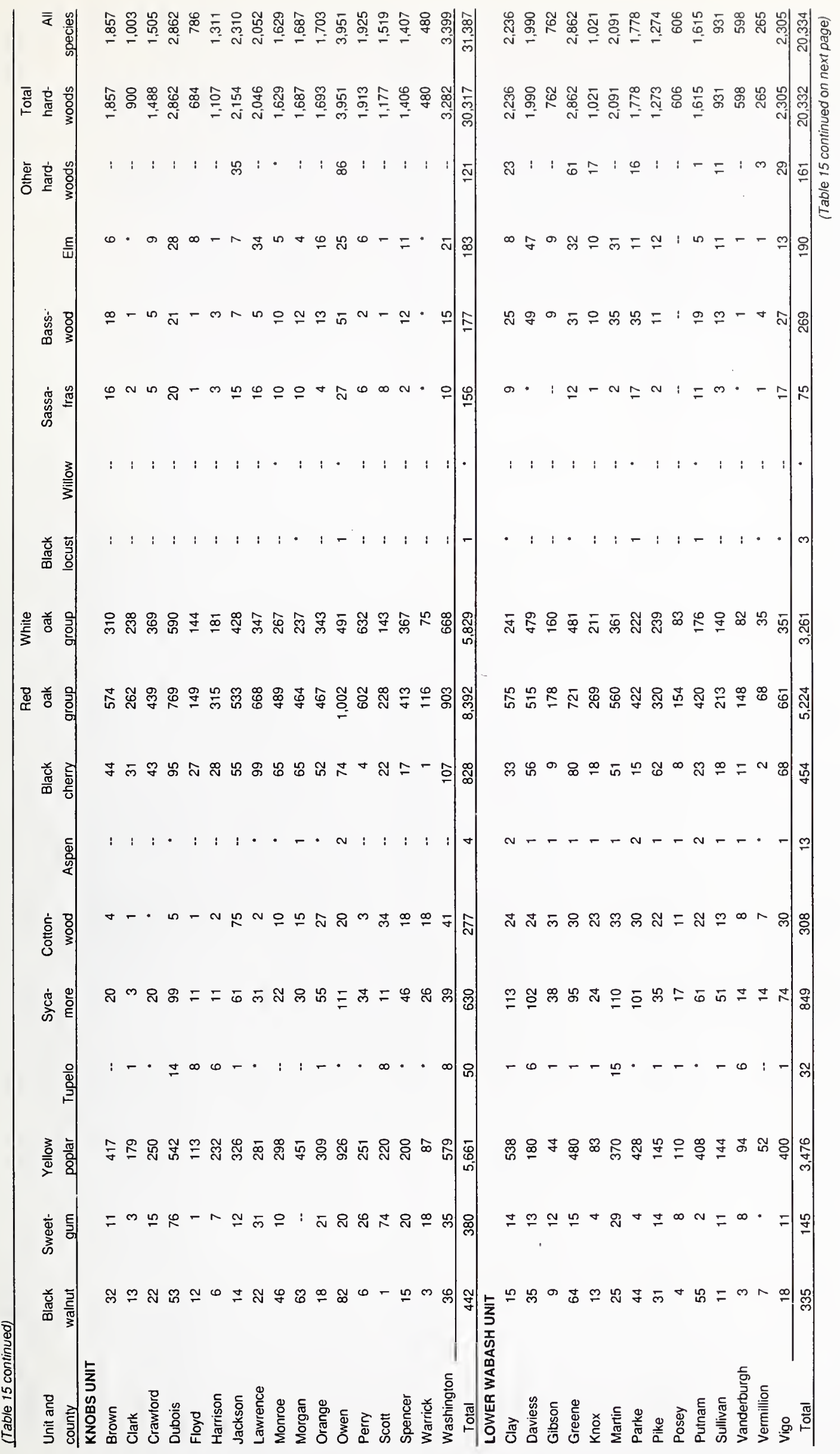




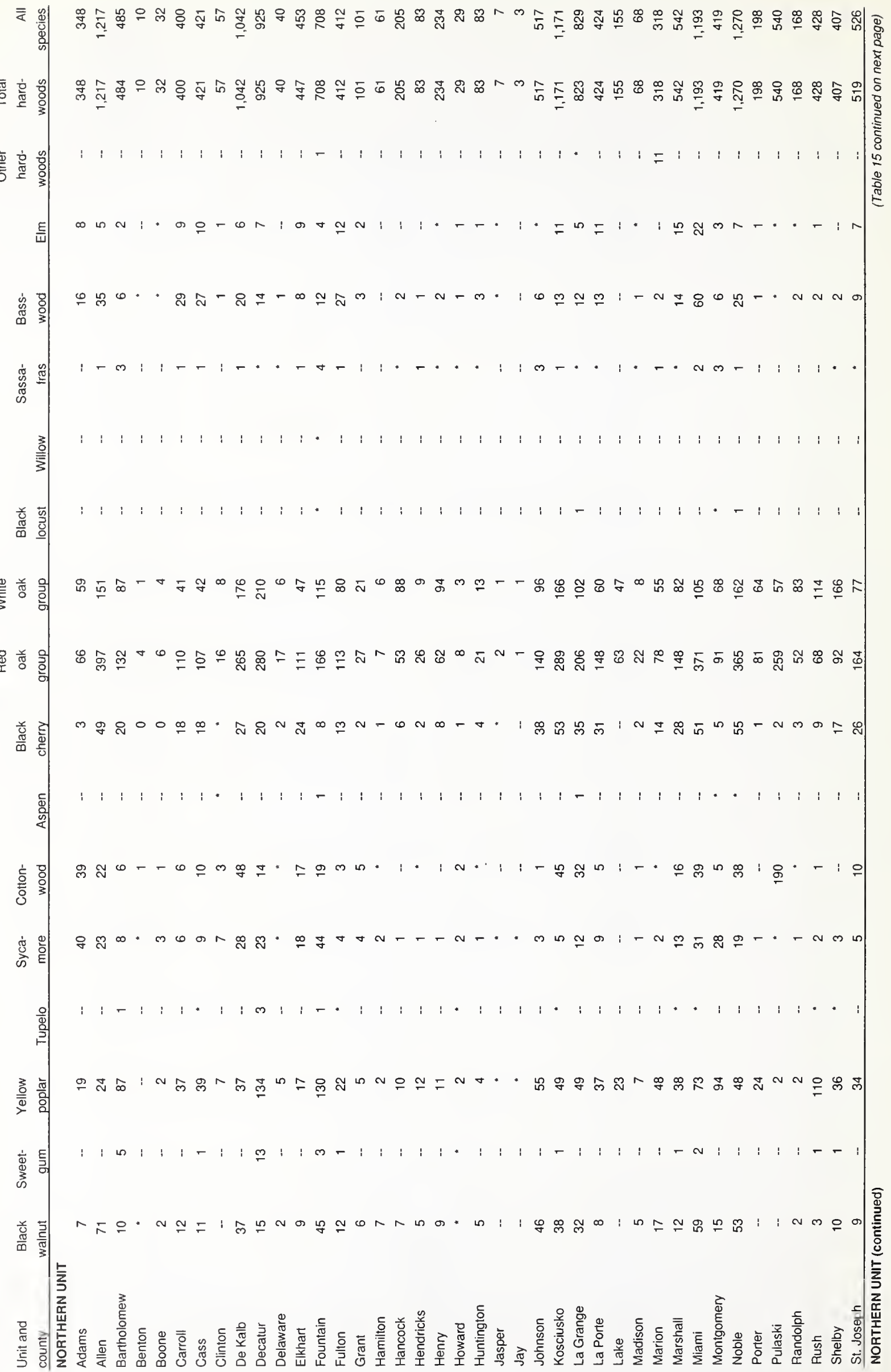




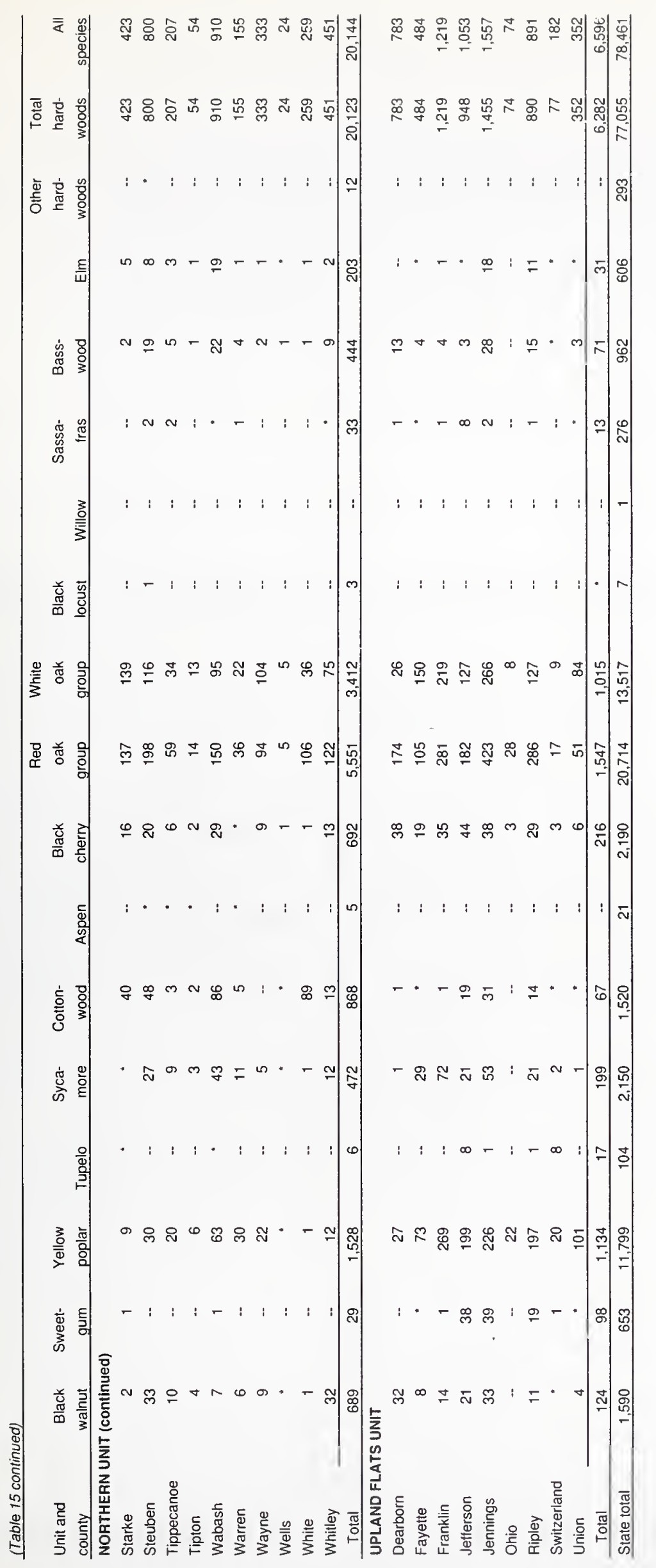




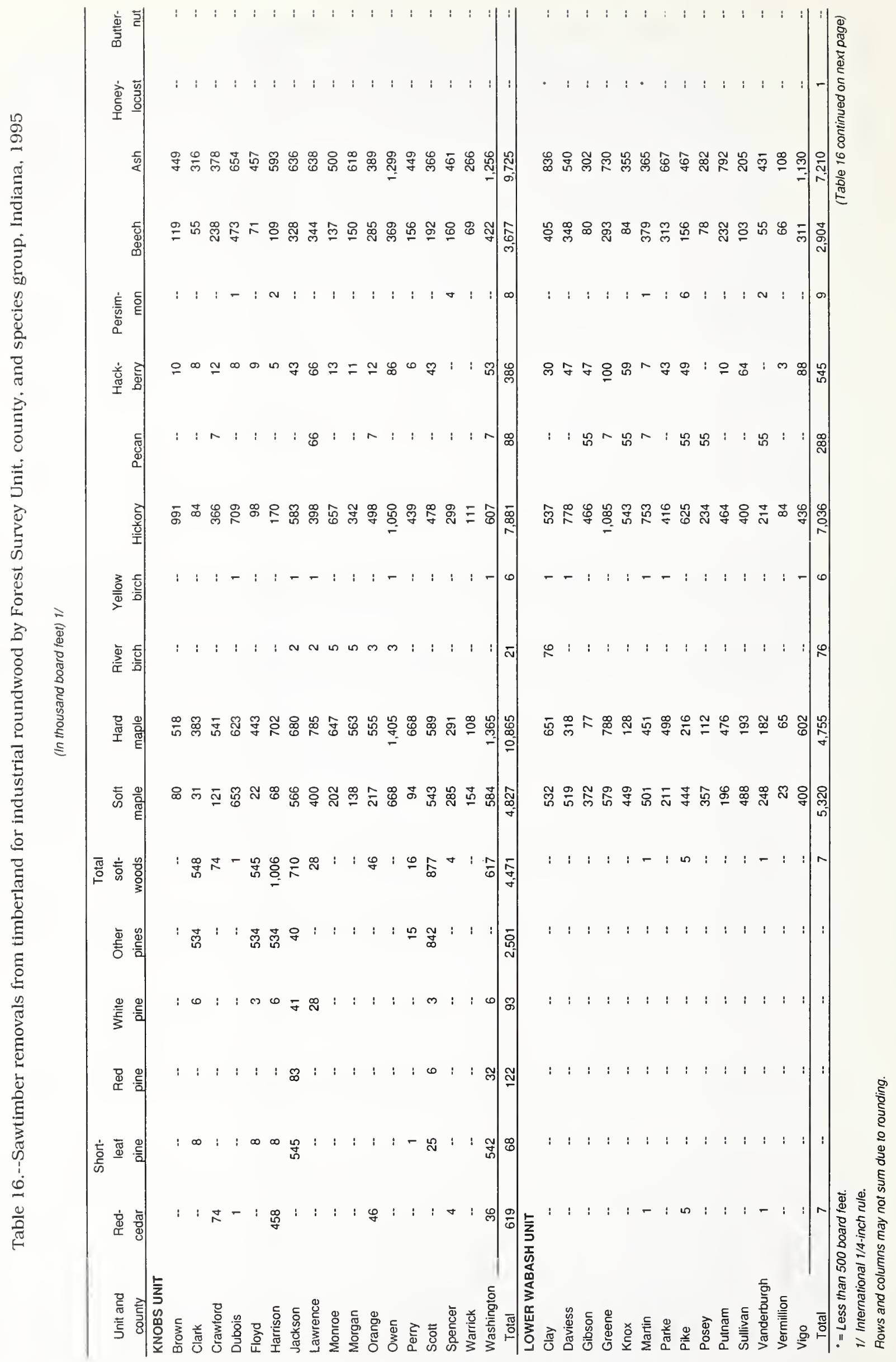




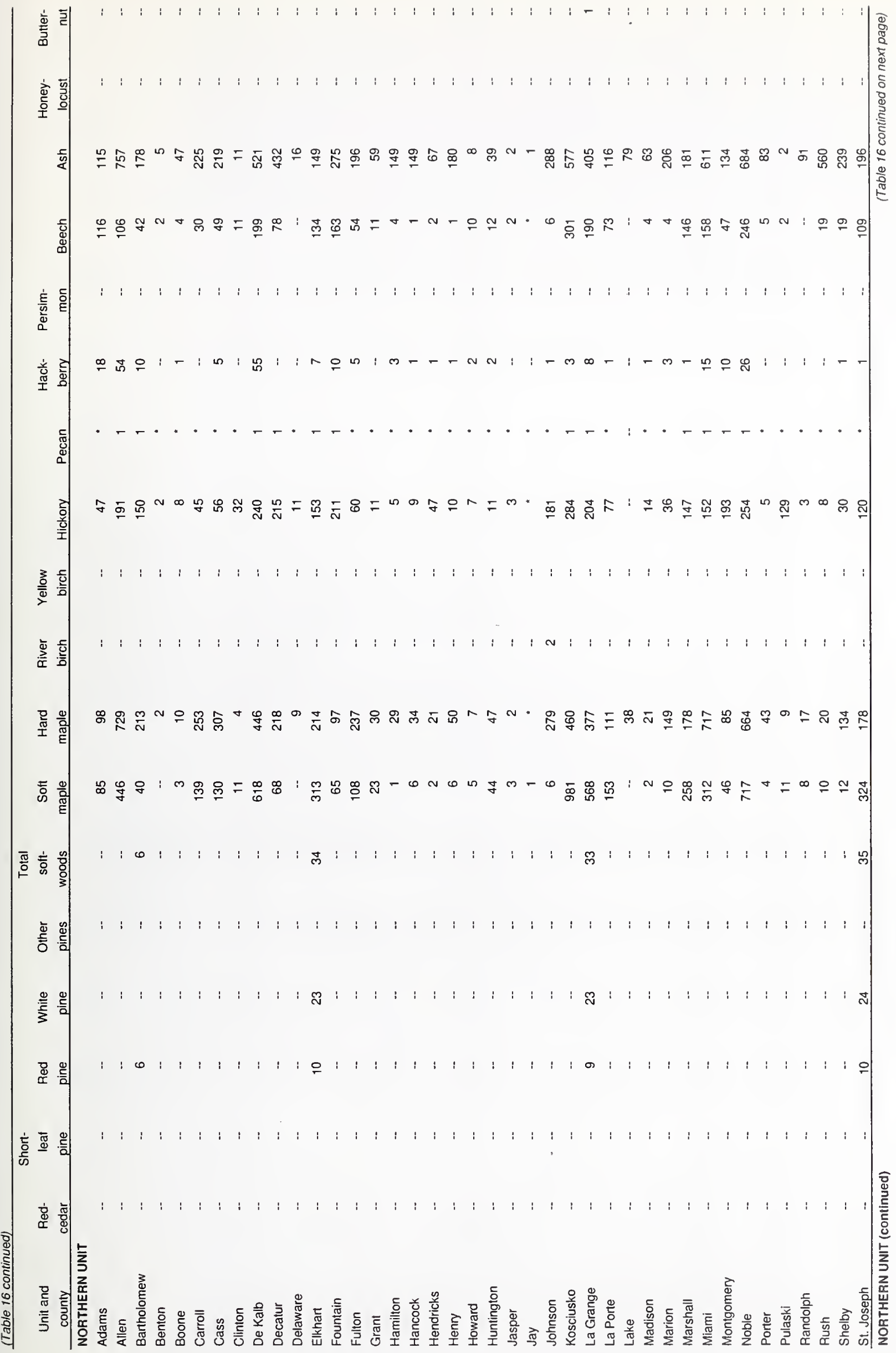




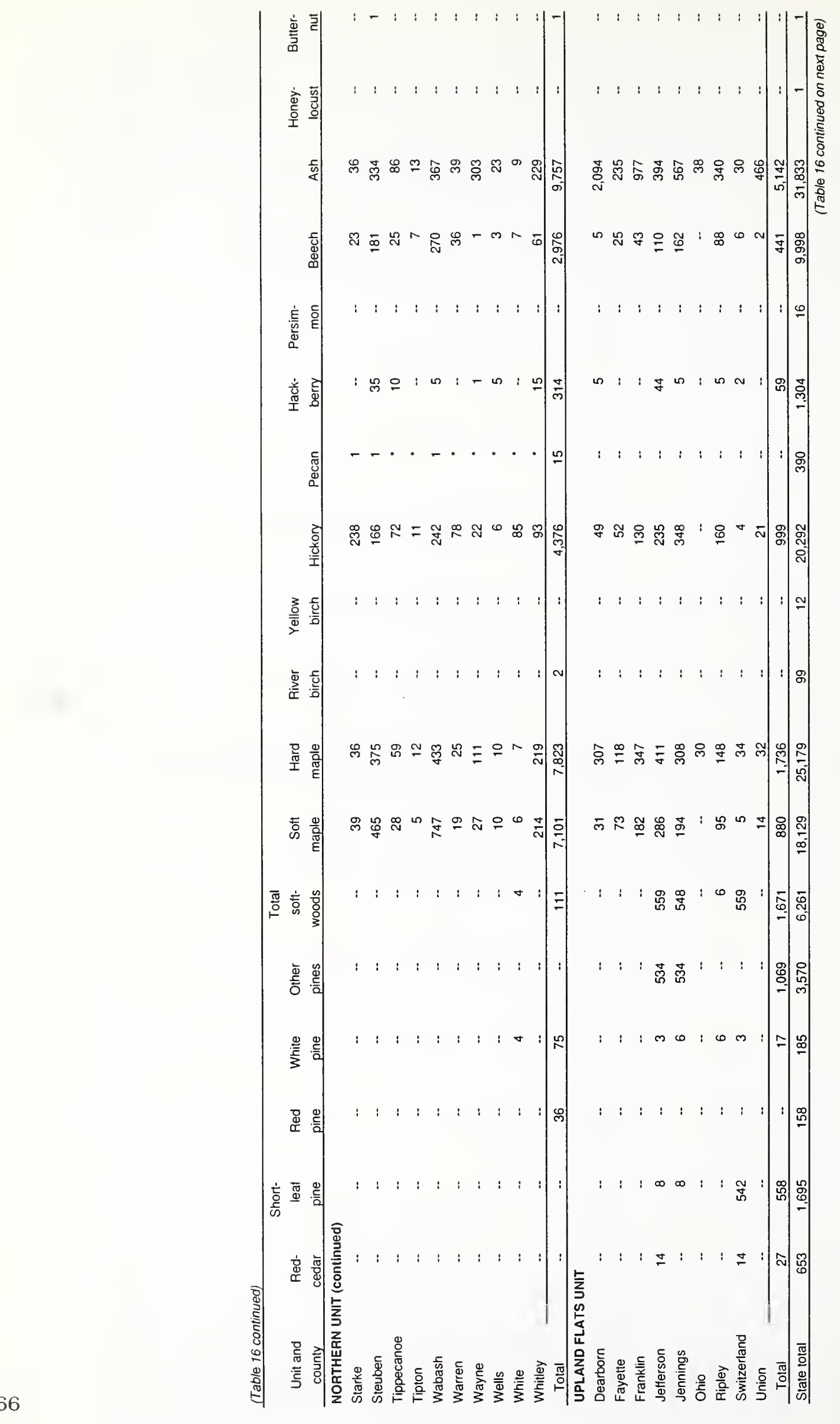




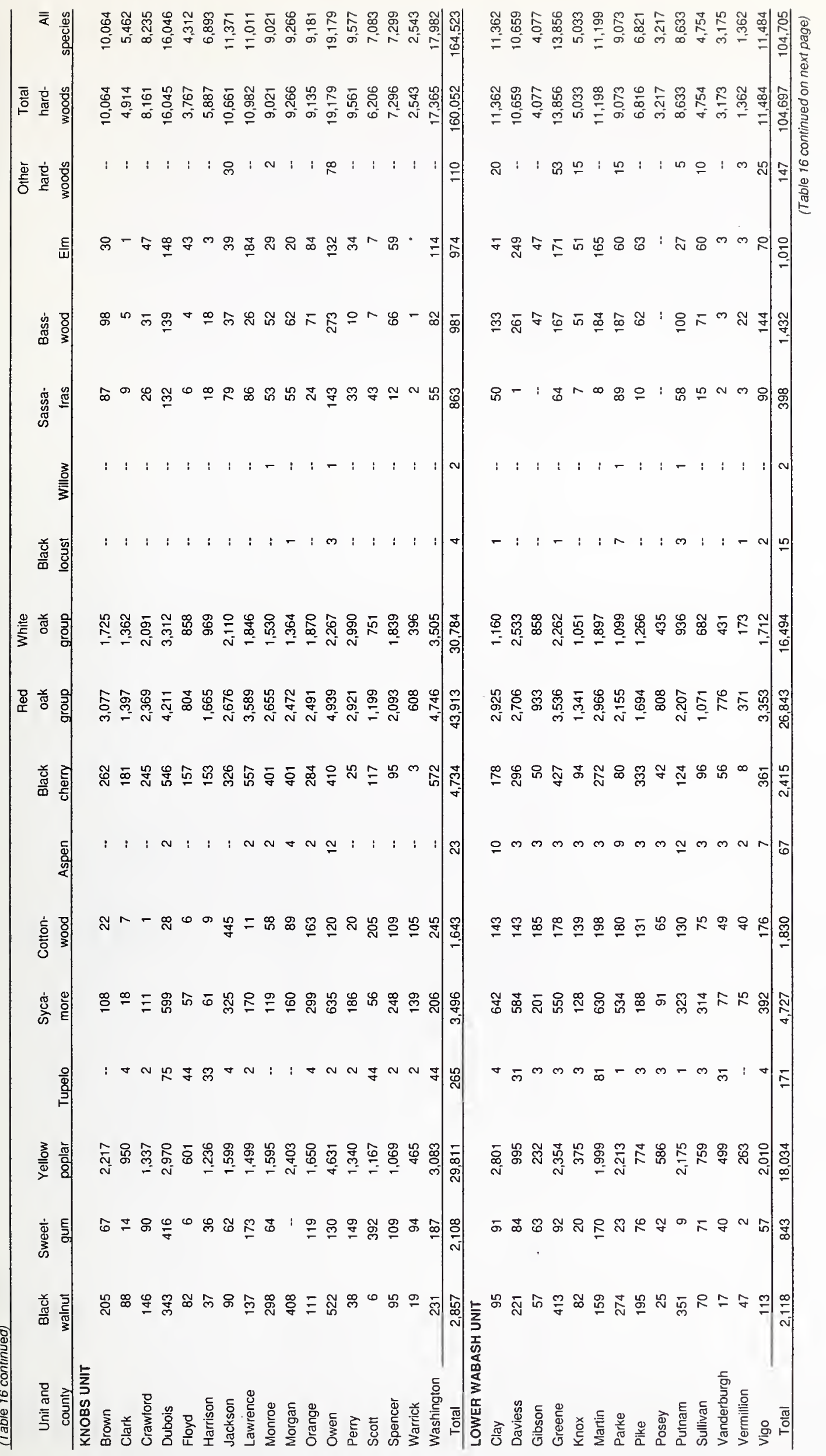




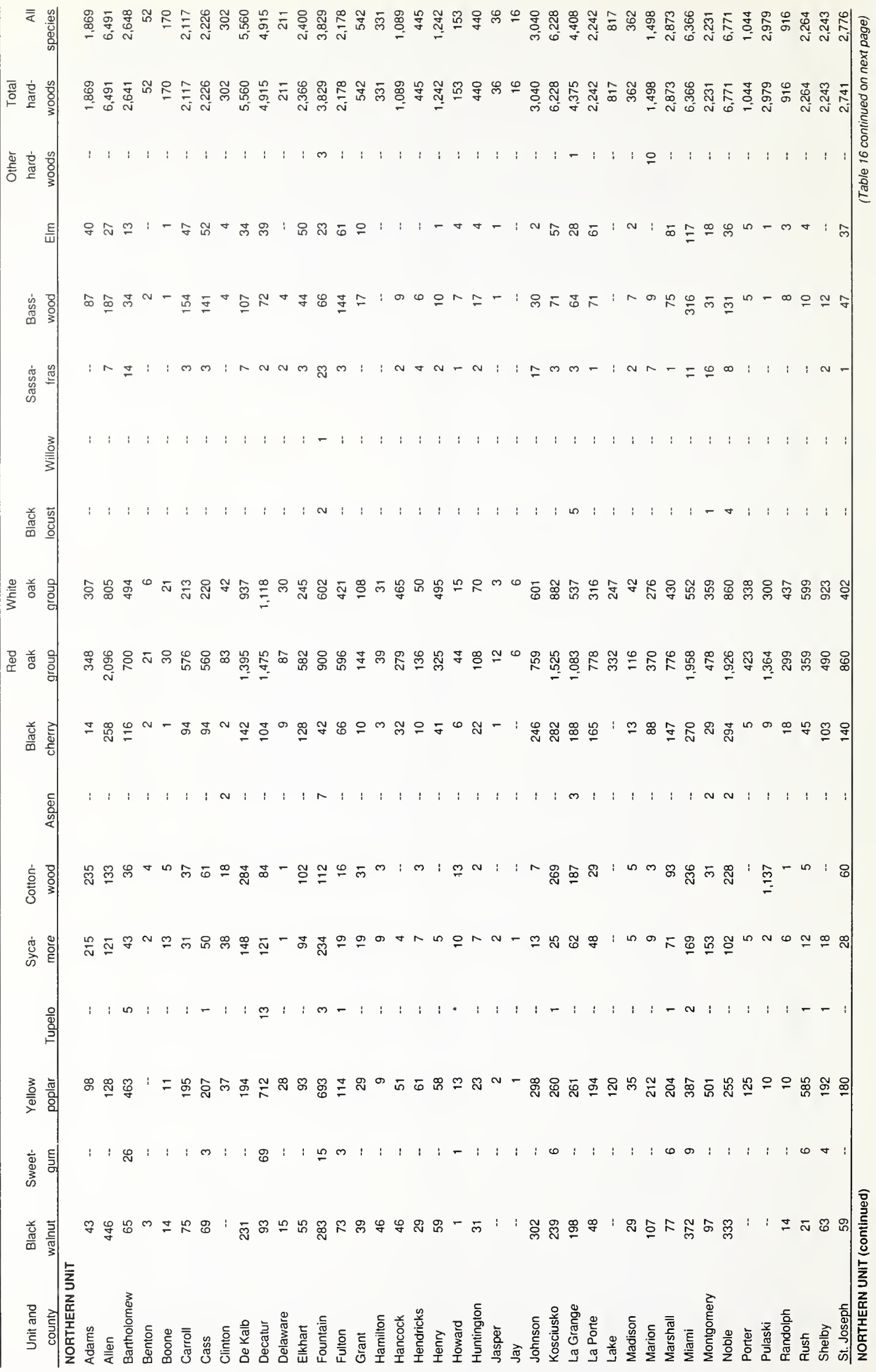




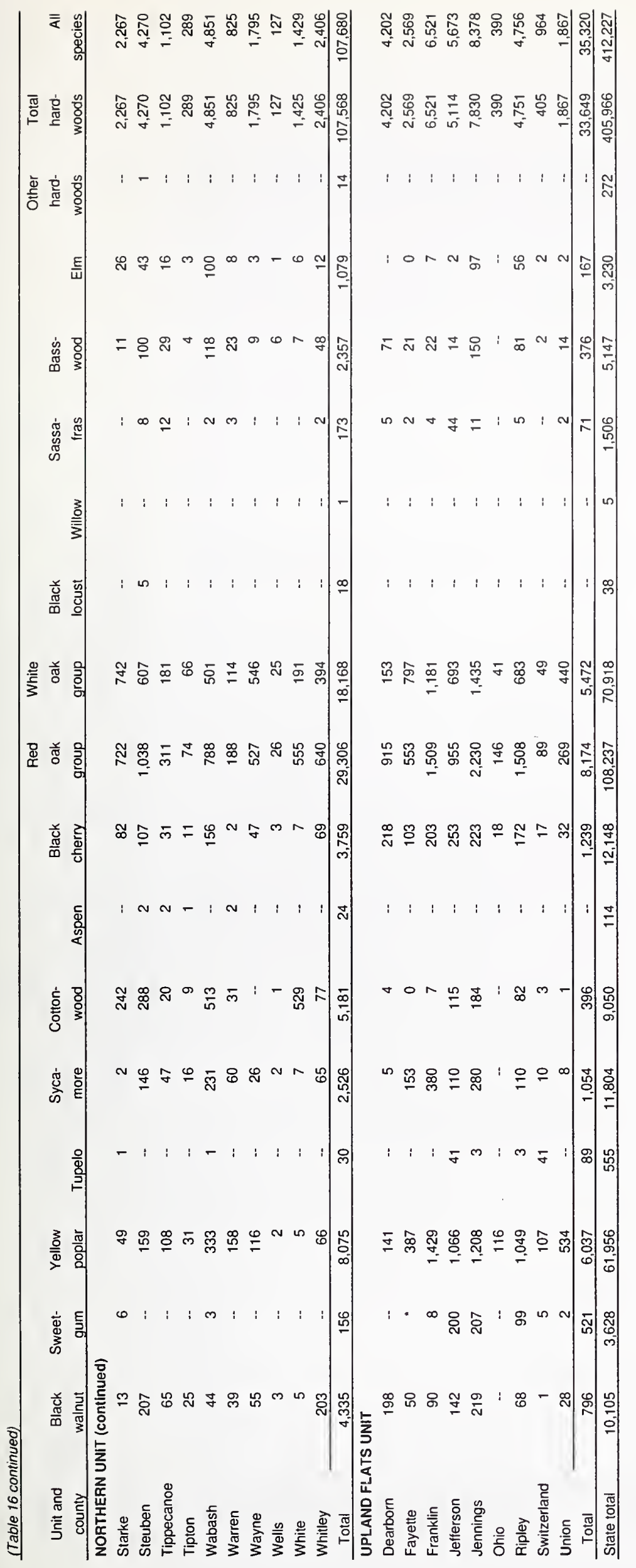




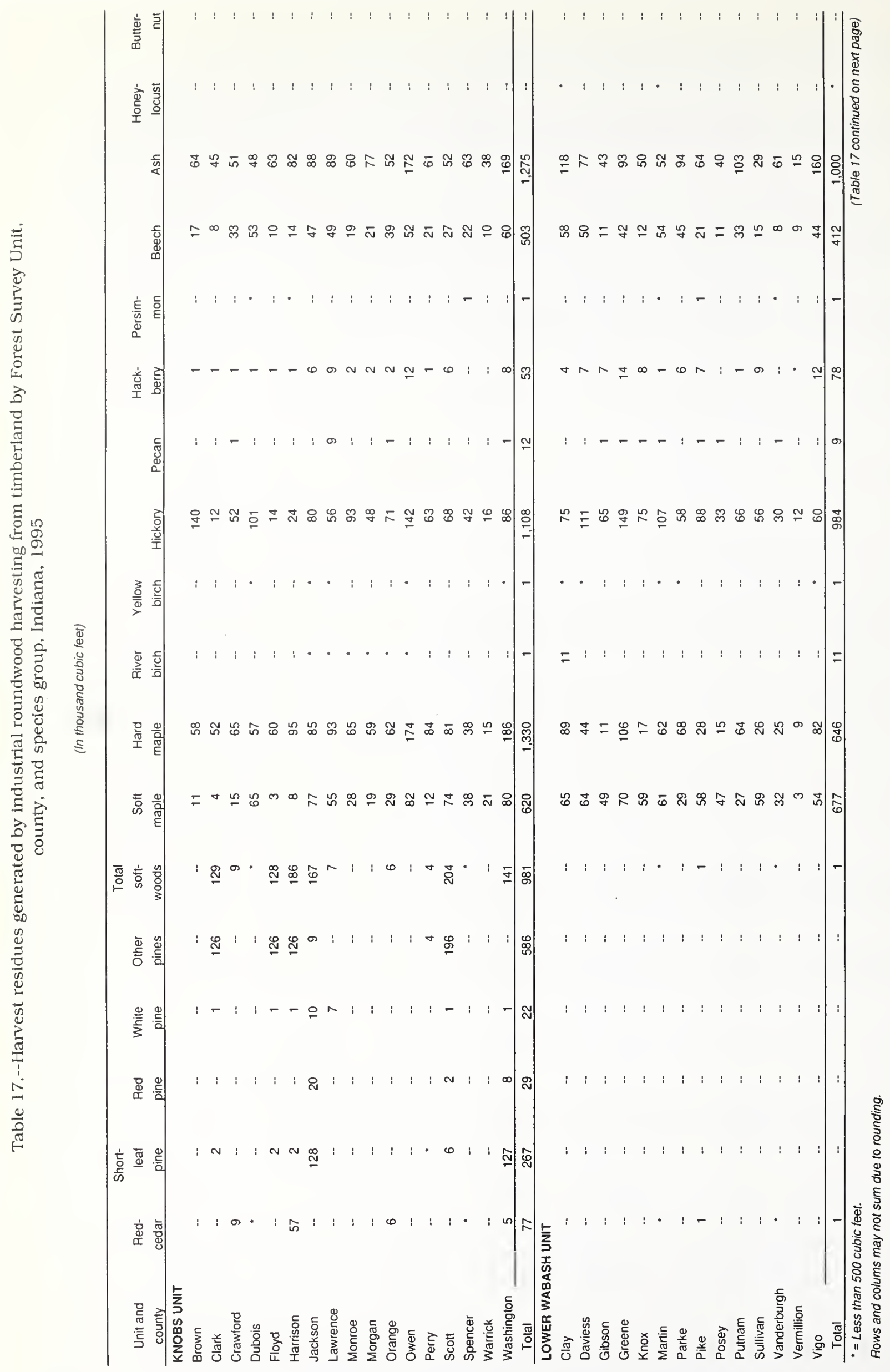


产 욤ำ

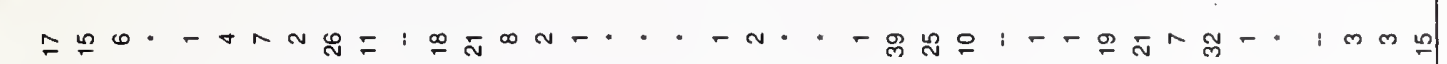

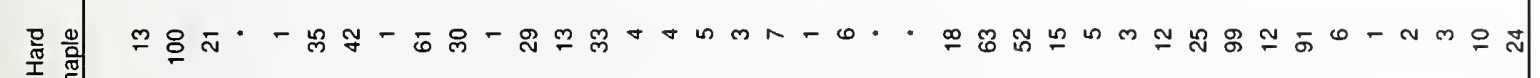

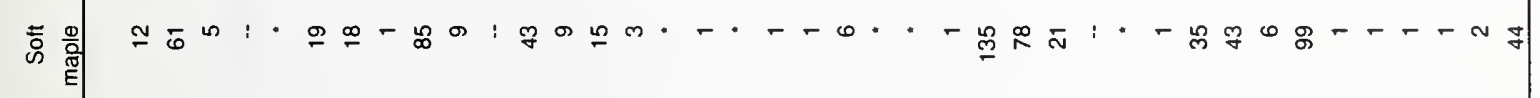

产高

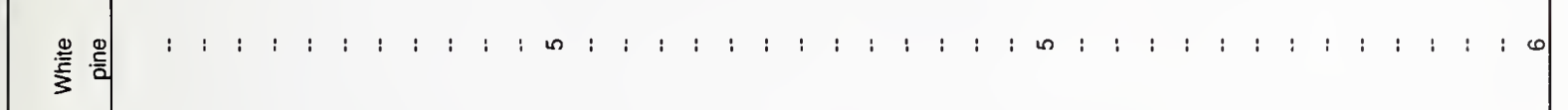

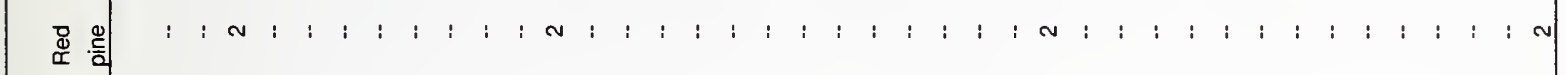

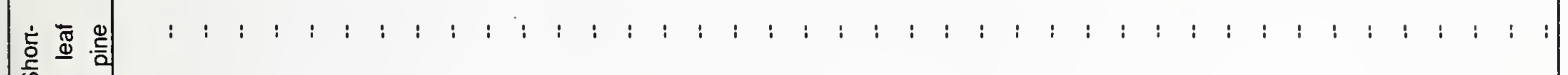




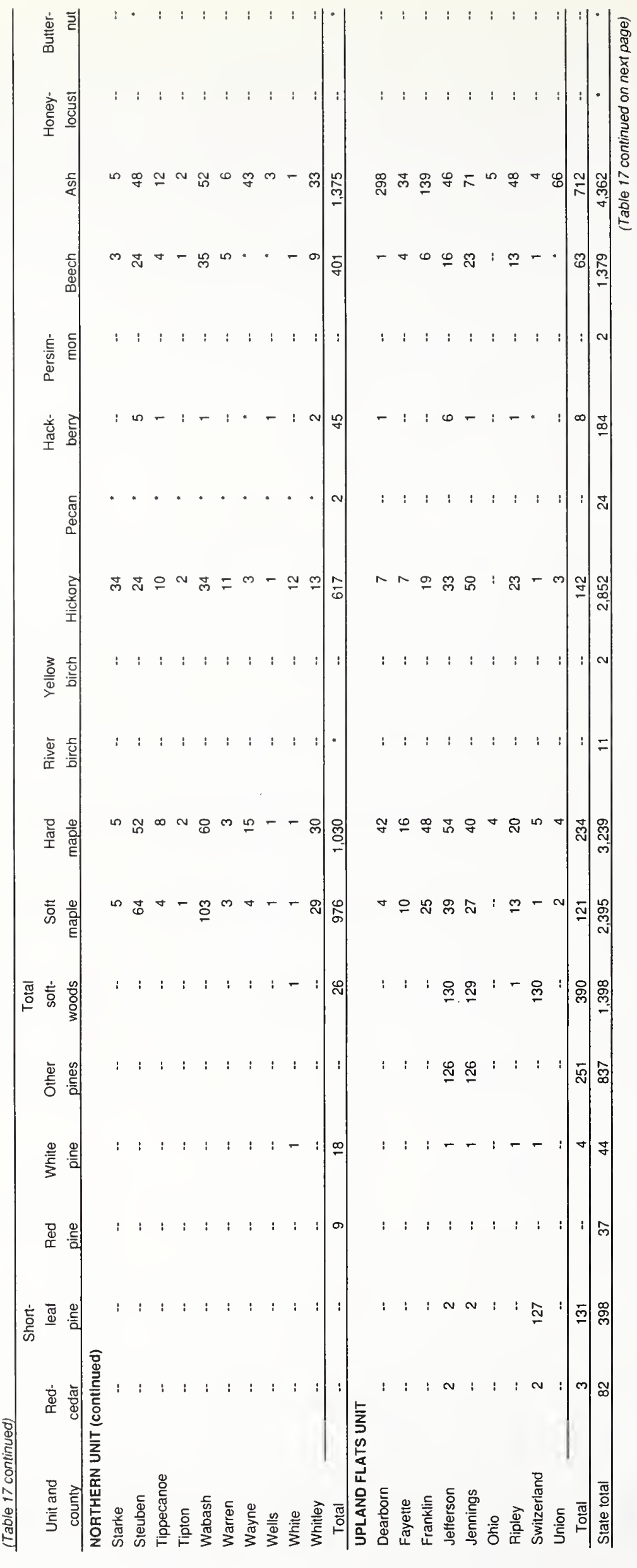




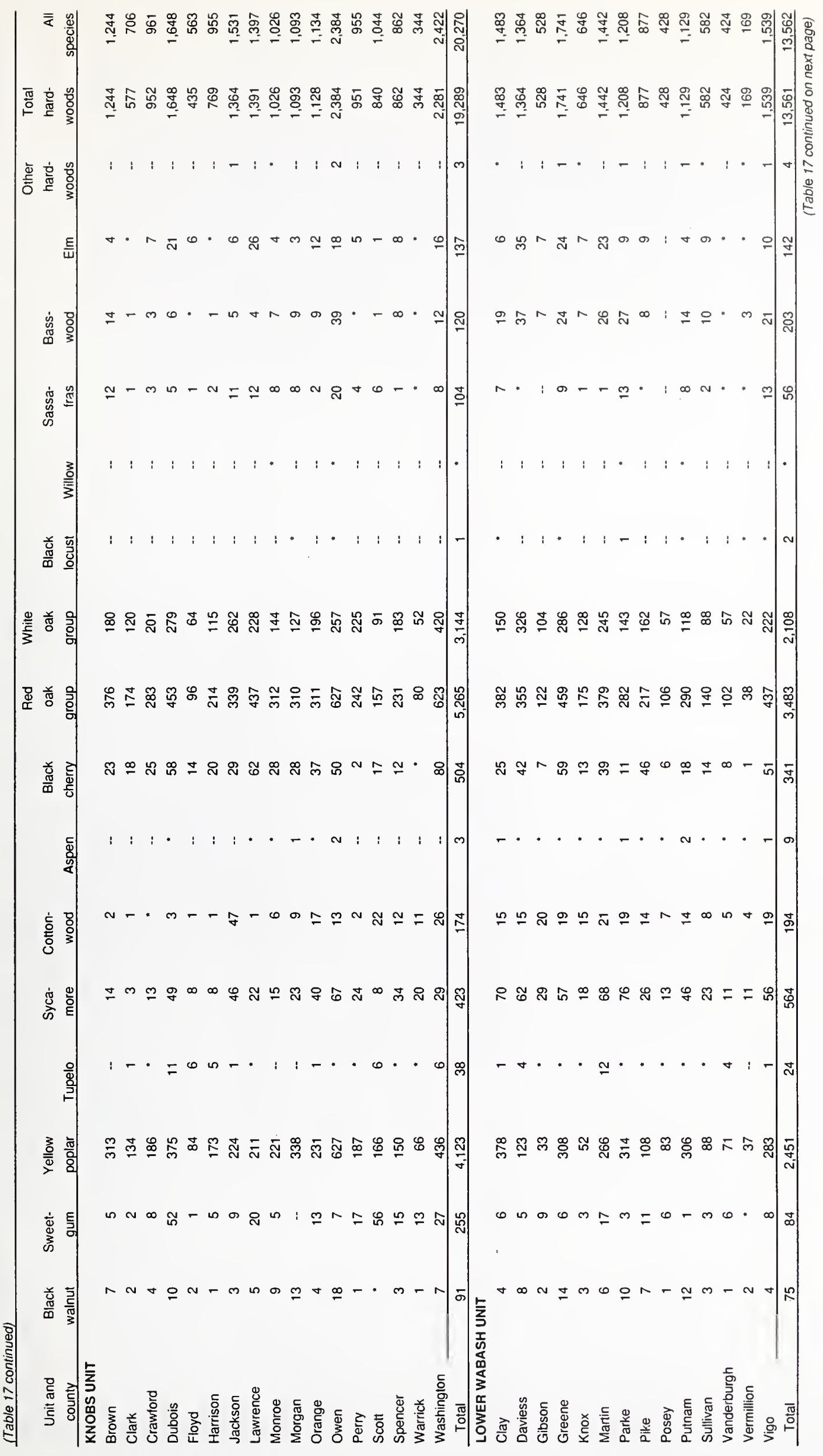




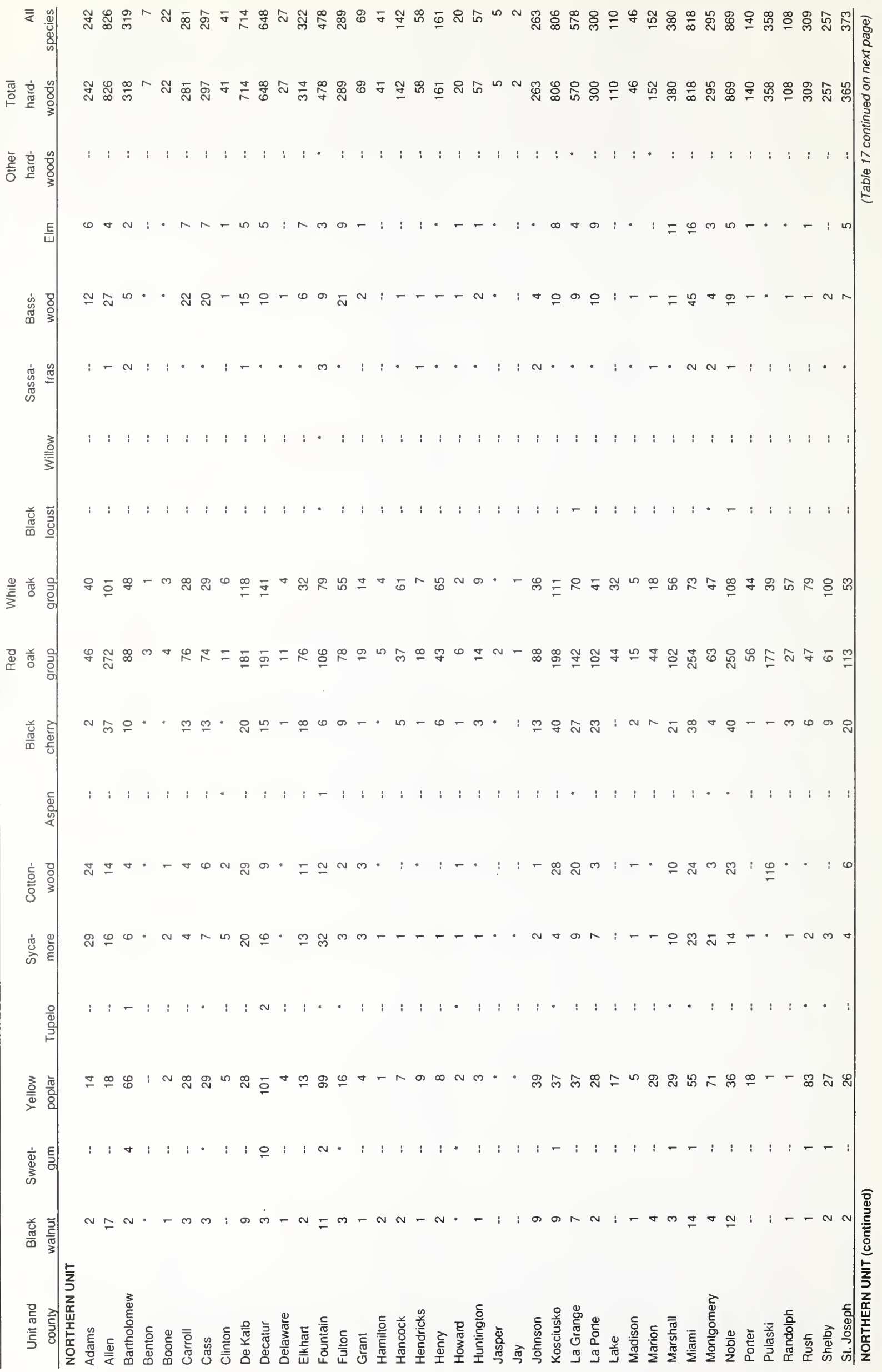




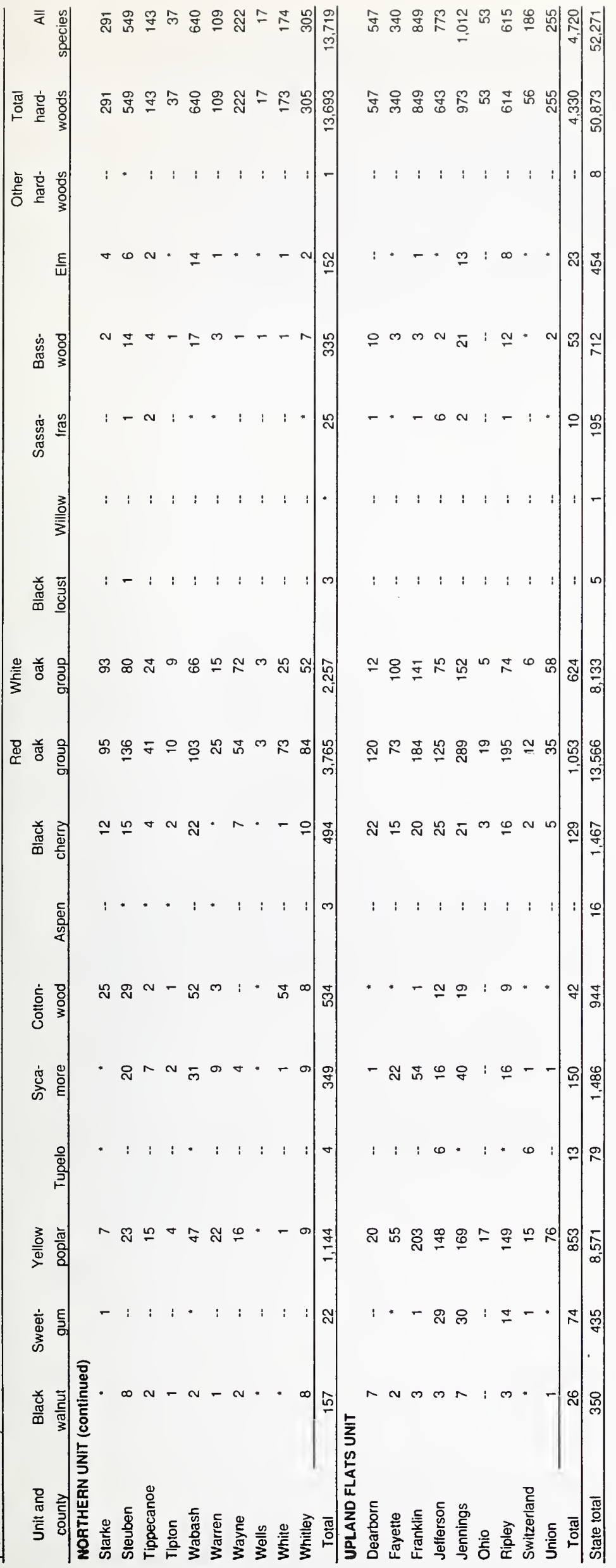


Table 18. - Residue produced at primary wood-using mills by type of material, type of use, and Forest Survey Unit, Indiana, 1995

(In thousand tons, green weight)

\begin{tabular}{|c|c|c|c|c|c|c|c|c|}
\hline \multirow{3}{*}{$\begin{array}{l}\text { Survey unit and } \\
\text { type of use }\end{array}$} & \multicolumn{6}{|c|}{ Wood residue } & \multirow{2}{*}{\multicolumn{2}{|c|}{ Bark }} \\
\hline & \multicolumn{2}{|c|}{ Total } & \multicolumn{2}{|c|}{ Coarse 1/ } & \multicolumn{2}{|c|}{ Fine $2 /$} & & \\
\hline & Softwood & Hardwood & Softwood & Hardwood & Softwood & Hardwood & Softwood & Hardwood \\
\hline \multicolumn{9}{|l|}{ KNOBS UNIT } \\
\hline Fiber products & 0.1 & 138.1 & 0.1 & 129.5 & -- & 8.6 & -- & 1.9 \\
\hline Charcoal & -- & 0.9 & -- & 0.7 & -- & 0.2 & -- & 0.3 \\
\hline Industrial fuel-mill & * & 43.6 & -- & 31.4 & $*$ & 12.2 & -- & 5.2 \\
\hline Industrial fuel-sold & * & 58.7 & 0.0 & 27.0 & * & 31.7 & -. & 6.4 \\
\hline Domestic fuel & 0.2 & 35.2 & 0.2 & 26.0 & 0.1 & 9.2 & 0.1 & 3.2 \\
\hline Miscellaneous 3/ & 1.5 & 60.6 & 1.1 & 14.7 & 0.4 & 45.8 & 0.3 & 69.8 \\
\hline Not used & * & 6.6 & * & 2.7 & -- & 3.9 & -- & 8.4 \\
\hline Total & 1.8 & 343.6 & 1.3 & 232.0 & 0.5 & 111.6 & 0.4 & 95.0 \\
\hline \multicolumn{9}{|l|}{ LOWER WABASH UNIT } \\
\hline Fiber products & -- & 81.4 & -- & 78.7 & -- & 2.7 & -- & -- \\
\hline Industrial fuel-mill & -- & 8.2 & -- & 5.7 & -- & 2.5 & -- & 1.8 \\
\hline Industrial fuel-sold & -. & 17.2 & -- & 5.4 & -- & 11.8 & - & -- \\
\hline Domestic fuel & -- & 16.0 & -- & 15.2 & -- & 0.8 & -. & 5.6 \\
\hline Miscellaneous 3/ & -- & 90.0 & -- & 40.8 & -- & 49.2 & -- & 42.0 \\
\hline Not used & $\therefore$ & 0.9 & -- & 0.4 & -- & 0.5 & -- & 9.6 \\
\hline Total & -- & 213.6 & -- & 146.2 & - & 67.4 & -- & 59.0 \\
\hline \multicolumn{9}{|l|}{ NORTHERN UNIT } \\
\hline Fiber products & -- & 96.3 & -- & 91.8 & -- & 4.5 & -- & 10.8 \\
\hline Industrial fuel-mill & -- & 59.3 & -- & 41.5 & -- & 17.8 & -- & 2.4 \\
\hline Industrial fuel-sold & -- & 11.3 & -- & 7.5 & -- & 3.8 & -- & 0.8 \\
\hline Domestic fuel & -- & 17.8 & -- & 17.8 & -- & - & -- & 3.4 \\
\hline Miscellaneous 3/ & 0.1 & 102.6 & * & 45.7 & 0.1 & 56.9 & 0.1 & 60.6 \\
\hline Not used & $*$ & 13.6 & $*$ & 8.2 & -- & 5.4 & 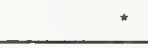 & 6.4 \\
\hline Total & 0.1 & 300.9 & $*$ & 212.5 & 0.1 & 88.4 & 0.1 & 84.4 \\
\hline \multicolumn{9}{|l|}{ UPLAND FLATS UNIT } \\
\hline Fiber products & -- & 8.5 & -- & 8.5 & -- & -- & -- & -- \\
\hline Industrial fuel-mill & -- & 2.1 & -- & 0.1 & -- & 2.0 & -- & * \\
\hline Domestic fuel & 0.1 & 3.6 & 0.1 & 3.6 & -- & -- & $*$ & 1.7 \\
\hline Miscellaneous 3/ & $*$ & 29.1 & -- & 15.3 & $*$ & 13.8 & -- & 9.7 \\
\hline Not used & * & 0.1 & -- & -- & * & 0.1 & -- & - \\
\hline Total & 0.1 & 43.4 & 0.1 & 27.5 & $\stackrel{ }{*}$ & 15.9 & $\star$ & 11.4 \\
\hline \multicolumn{9}{|l|}{ STATE TOTAL } \\
\hline Fiber products & 0.1 & 324.2 & 0.1 & 308.4 & -- & 15.8 & -- & 12.7 \\
\hline Charcoal & -. & 0.9 & -- & 0.7 & -- & 0.2 & -- & 0.3 \\
\hline Industrial fuel-mill & * & 113.2 & -- & 78.7 & * & 34.5 & -- & 9.4 \\
\hline Industrial fuel-sold & * & 87.2 & $*$ & 39.9 & $*$ & 47.3 & - & 7.2 \\
\hline Domestic fuel & 0.3 & 72.6 & 0.2 & 62.7 & 0.1 & 10.0 & 0.1 & 13.9 \\
\hline Miscellaneous 3/ & 1.6 & 282.3 & 1.1 & 116.6 & 0.5 & 165.7 & 0.4 & 182.0 \\
\hline Not used & ${ }^{*}$ & 21.2 & $*$ & 11.3 & * & 9.9 & $*$ & 24.4 \\
\hline Total & 2.0 & 901.5 & 1.4 & 618.2 & 0.6 & 283.3 & 0.5 & 249.8 \\
\hline
\end{tabular}

1/ Suitable for chipping such as slabs, edgings, veneer cores, etc.

2/ Not suitable for chipping such as sawdust, veneer clippings, etc.

3/ Livestock bedding, mulch, small dimension, and specialty items.

Rows and columns may not sum due to rounding. 
The United States Department of Agriculture (USDA) prohibits discrimination in its programs on the basis of race, color, national origin, sex, religion, age, disability, political beliefs, and marital or familial status. (Not all prohibited bases apply to all programs.) Persons with disabilities who require alternative means of communication of program information (braille, large print, audiotape, etc.) should contact the USDA Office of Communications at (202) 720-2791.

To file a complaint, write the Secretary of Agriculture, U.S. Department of Agriculture, Washington, DC 20250, or call 1-800-245-6340 (voice), or 202-720-1127 (TDD). USDA is an equal employment opportunity employer. 
Hackett, Ronald L.; Settle, Jeff.

1998. Indiana's timber industry-an assessment of timber product output and use, 1995. Resour. Bull. NC-193. St. Paul, MN: U.S. Department of Agriculture, Forest Service, North Central Research Station. 76 p.

Discusses recent Indiana forest industry trends; production and receipts of saw logs, pulpwood, and veneer logs; and production of other timber products in 1995. Reports on harvest residue, on wood and bark residue generated at primary wood-using mills, and on disposition of this mill residue.

KEY WORDS: Saw logs, pulpwood, veneer logs, residue. 
Our job at the North Central Forest Experiment Station is discovering and creating new knowledge and technology in the field of natural resources and conveying this information to the people who can use it. As a new generation of forests emerges in our region, managers are confronted with two unique challenges: (1) Dealing with the great diversity in composition, quality, and ownership of the forests, and (2) Reconciling the conflicting demands of the people who use them. Helping the forest manager meet these challenges while protecting the environment is what research at North Central is all about.

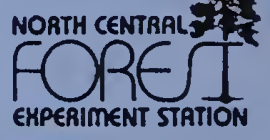

